\title{
Sedimentary processes controlling ultralong cells of littoral transport : placer formation and termination of the Orange sand highway in southern Angola
}

\author{
EDUARDO GARZANTI ${ }^{1 *}$, PEDRO DINIS ${ }^{2}$, PIETER VERMEESCH $^{3}$, SERGIO ANDÒ $^{1}$, \\ ANNETTE HAHN ${ }^{4}$, JOÃO HUVI ${ }^{5}$, MARA LIMONTA ${ }^{1}$, MARTA PADOAN ${ }^{1}$ ALBERTO \\ RESENTINI $^{1}$, MARTIN RITTNER ${ }^{3}$, GIOVANNI VEZZOLI ${ }^{1}$
}

${ }^{1}$ Laboratory for Provenance Studies, Department of Earth and Environmental Sciences, Università di Milano-Bicocca, 20126 Milano, Italy

2 IMAR-CMA Centro do Mar e Ambiente, Departamento de Ciências da Terra, Universidade de Coimbra, Largo Marquês de Pombal, 3000-272 Coimbra, Portugal

${ }^{3}$ London Geochronology Centre, Department of Earth Sciences, University College London, London WC1E $6 B T, U K$

${ }^{4}$ MARUM Center for Marine Environmental Sciences, University of Bremen, Bremen, Germany

${ }^{5}$ Marine and Environmental Sciences Centre, University Katyavala Bwila, Angola

* Corresponding author. Tel.: +39-02-64482088

E-mail: eduardo.garzanti@unimib.it(E. Garzanti),pdinis@dct.uc.pt (P. Dinis),p.vermeesch@ucl.ac.uk (P.Vermeesch), sergio.ando@unimib.it (S. Andò), ahahn@marum.de (A.Hahn), hjoaobaptistahuvi@yahoo.com.br (J.Huvi),mara.limonta@unimib.it (M.Limonta), marta.padoan@unimib.it (M.Padoan), alberto.resentini@unimib.it (A. Resentini),m.rittner@ucl.ac.uk (M.Rittner), giovanni.vezzoli@unimib.it (G. Vezzoli)

Key words: Sedimentary petrology, heavy minerals, detrital-zircon geochronology, Raman counting of deep-sea silt, grain density and geochemistry of placer deposits, garnet and pyroxene chemistry, longshore sediment transport, Moçamedes Desert and Cunene River sands. 


\begin{abstract}
This study focuses on the causes, modalities and obstacles of sediment transfer in the longest cell of littoral sand drift documented on Earth so far. Sand derived from the Orange River is dragged by swell waves and persistent southerly winds to accumulate in four successive dunefields in coastal Namibia to Angola. All four dunefields are terminated by river valleys, where eolian sand is flushed back to the ocean. And yet sediment transport continues at sea, tracing a $1800 \mathrm{~km}$-long submarine sand highway. Sand drift would extend northward to beyond the Congo if the shelf did not become progressively narrower in southern Angola, where drifting sand is funnelled towards oceanic depths via canyon heads connected to river mouths. Garnet-magnetite placers are widespread along this coastal stretch, indicating systematic loss of the low-density feldspatho-quartzose fraction to the deep ocean. More than half of Moçamedes Desert sand is derived from the Orange River, and the rest in similar proportions from the Cunene River and from the Swakop and other rivers draining the Damara orogen in Namibia. The Orange fingerprint, characterized by basaltic rock fragments, clinopyroxene grains, and bimodal zircon-age spectra with peaks at $\sim 0.5$ and $\sim 1.0 \mathrm{Ga}$, is lost abruptly at Namibe, and beach sands farther north have abundant feldspar, amphibole-epidote suites, and unimodal zircon-age spectra with peak at $2.0 \mathrm{Ga}$, documenting local provenance from Paleoproterozoic basement. Along this oblique-rifted continental margin, beach placers are dominated by Fe-Ti-Cr oxides with more monazite than garnet, and thus have a geochemical signature sharply different from beach placers found all along the Orange littoral cell. Highresolution mineralogical studies allow us to trace sediment dispersal over distances of thousands of kilometers, providing essential information for the correct reconstruction of source-to-sink relationships in hydrocarbon exploration and to predict the long-term impact of man-made infrastructures on coastal sediment budgets.
\end{abstract}




\begin{abstract}
Water dissolving ... and water removing / There is water at the bottom of the ocean / Letting the days go by / Water flowing underground / Into the blue again / Into the silent water / Under the rocks and stones / There is water underground / And you may ask yourself / Where does that highway go to?

Talking Heads, Once in a lifetime, 1980.
\end{abstract}

\title{
INTRODUCTION
}

1

2 The long-distance transfer of huge detrital masses from one site to another on the Earth's surface is

3 of essence to understand sedimentological processes, enhance the resolution of source-to-sink

4 studies for hydrocarbon exploration, and improve the quality of environmental management

5 (Dickinson, 1988; Kaminsky et al., 2010; Scott et al., 2014). Hundreds of million tons of sediment

6 are carried each year for thousands of kilometers along the largest fluvial systems, such as the

7 Amazon, the Ganga-Brahmaputra or the Yellow River (Hay, 1998; Milliman \& Farnsworth, 2011).

8 Equally established is the underwater transport of large sediment volumes over similar distances via

9 turbidity currents, as across the present Bengal and Indus Fans or their ancient analogues (Ingersoll

10 et al., 2003). Far less documented is the transport of large sediment volumes in the shallow sea,

11 which can cover distances of a thousand kilometers and more under the action of persistent

12 longshore currents. The major implications of littoral sediment transport for the paleogeographic

13 interpretation of ancient sedimentary deposits remain notably underexplored.

14 Only a few cases of modern ultralong-distance littoral sand transport have been documented in 15 detail so far. Swell-driven coastal-transport systems hundreds of kilometers in length exist in many 16 parts of the world (Silvester, 1962; Davies, 1972), as in southern Brasil (Calliari \& Toldo, 2016) or 17 eastern Australia, where sand is dragged alongshore for $\sim 1500 \mathrm{~km}$ to north of Fraser Island, the 18 largest sand island on Earth (Boyd et al., 2008). Even longer is the littoral cell fed by the Orange 19 River, the object of the present study, rivaled in length only by the mud-dominated Amazon cell 
20 (Allison \& Lee, 2004; dos Santos et al., 2016). Littoral dispersal of Nile sand under the action of 21 longshore currents fuelled by strong northwesterly winds, which has fed the beaches of Gaza and 22 Israel through most of the Quaternary, terminates at Haifa Bay and Akhziv submarine canyon 700 $23 \mathrm{~km}$ from the Delta (Inman \& Jenkins, 1984; Garzanti et al., 2015a). The littoral cell associated with 24 the Columbia River, the third largest in the United States by discharge, extends for $165 \mathrm{~km}$ only 25 (Ruggiero et al., 2005), although sand transport by turbidity currents continues for $\sim 1100 \mathrm{~km}$ along 26 a devious route reaching far into the Pacific Ocean (Zuffa et al., 2000).

27 The present article builds upon previous studies that monitored sediment dispersal along the Atlantic coast of southern Africa - from the Orange River to the Namib Erg, and beyond to the Skeleton Coast and Moçamedes Desert of southernmost Angola (Vermeesch et al., 2010; Garzanti et al., 2012a, 2014, 2015b) - and focuses on physical processes of sediment mixing and unmixing

31 in the terminal tract of this ultralong submarine sand highway (Fig. 1). We will investigate specifically provenance of sand accumulating in the Moçamedes Desert north of the Cunene River mouth (Fig. 2) and along the Angolan coast farther north (Fig. 3), in order to understand where, how, and why the compositional fingerprint of Orange-derived sand is eventually lost after $\sim 1800$ $\mathrm{km}$ of littoral drift. We will examine whether and to what extent northward sand transport is blocked on land by incised river valleys and/or at sea by submarine canyons, the influence of atmospheric and oceanic circulation, and the role played by shelf width, representing both a control and a consequence of longshore sediment drift. An accurate evaluation of such factors is essential to understand the physical processes promoting such a large-scale transfer of sediment volumes, and how they are reflected in the composition of continental-margin sediments.

\section{THE ANGOLAN COAST}

44 The coastal region of southern Angola is affected profoundly by atmospheric and oceanic 45 circulation in the southeastern Atlantic Ocean. Here the warm, southward flowing Angola Current 
converges with the cold, northward flowing Benguela Current, forming the Angola-Benguela front

47 (Meeuwis \& Lutjeharms, 1990; Shannon \& Nelson, 1996; Lass et al., 2000). Reflecting this oceanic circulation pattern and the influence of the subtropical high-pressure system, climate along the coast is very arid between $\sim 30^{\circ} \mathrm{S}$ and $\sim 15^{\circ} \mathrm{S}$. Annual rainfall increases progressively from as low as 15 $\mathrm{mm}$ at Foz do Cunene and Baia dos Tigres, to $20 \mathrm{~mm}$ at Tombua, $50 \mathrm{~mm}$ at Namibe, and $200 \mathrm{~mm}$ at Lobito (Guilcher, 2010). Rainfall increases much more rapidly inland to reach 1000-1500 mm/a in the mountainous hinterland, where climate becomes humid subtropical, temperate-highland tropical with dry winters, or even of savanna type (Peel et al., 2007; Jury, 2010). This gradient is blurred at latitudes $>20^{\circ} \mathrm{S}$, where rainfall hardly reaches $500 \mathrm{~mm} / \mathrm{a}$ in the hinterland and temperature decreases significantly marking the transition to cold desert climate. Southerly to south-westerly winds generated in subtropical high-pressure systems prevail throughout the year; inversions may take place during the night, when continental areas become colder than the ocean.

8 The intensities of the Angola and Benguela currents are seasonally variable and the position of the Angola-Benguela front usually shifts between $14^{\circ} \mathrm{S}$ and $16^{\circ} \mathrm{S}$ (Hardman-Mountford et al., 2003), north of which climate changes from hot desert to hot semi-arid. Responding to seasonal variation in oceanic circulation and solar radiation, the region is characterized by alternating wet and dry seasons varying with latitude and distance from the coast. In the continental hinterland, the rainy season usually starts in September or October and lasts up to 7 months at lower latitudes, whereas it may be delayed until December at higher latitudes. No rainy season exists along the hyperarid southern coast, where much of the precipitation is in the form of fog (locally called cassimbo). The region is also affected by the so-called Benguela Niño, when the Angola-Benguela front is displaced southward causing the advection of warm, highly saline waters as far as $25^{\circ} \mathrm{S}$ (Shannnon et al., 1986; Kirst et al., 1999; Rouault et al., 2007). The recurrence of major floods, as those of the Bero and Giraul Rivers in April 2001 or March 2011 that caused casualties of tens of people, displacement of thousands of families, and loss of a large extent of arable land, may be associated 
71

72

73

74

75

76

77

78

79

80

81

82

83

84

85

86

87

88

89

90

91

92

93

94

95

96

with the Benguela Niño phenomenon (Manhique et al., 2015). Estimates on sediment volumes carried at sea during such catastrophic events are unfortunately lacking.

The microtidal coast of Angola (mean spring tide 1-2 m) is characterized by extensive northward sediment transport. Littoral drift is generated by a powerful southerly swell originating from persistent stormy winds between $40^{\circ}$ and $60^{\circ} \mathrm{S}$, far away in the Southern Ocean. Scarcely affected by either local winds or the Benguela Current, such wave-driven transport system extends from Cape Town to the Gulf of Guinea, its direction being controlled by the oblique incidence of the wave front to the coast. In proximity of coastal re-entrants, waves are refracted and lose their longshore transporting capacity; sand thus accumulates offshore as a sand spit. Before it was detached from shore in March 1962, the $37 \mathrm{~km}$-long spit enclosing Baia dos Tigres, characterized by $60 \mathrm{~m}$-thick sand deposits at its northern end and completely devoid of vegetation owing to hyperarid climate, was the longest of the African coast (Guilcher et al., 1974).

\section{SAMPLING AND ANALYTICAL METHODS}

In order to monitor changes in sediment composition in the terminal tract of the Orange littoral cell, 24 sand samples of beach, eolian and fluvial sands from south of Tombua to Lucira were collected in southern Angola in June 2015, including three beach placers (Fig. 4). To quantify provenance of dune and beach sand in the Moçamedes coastal desert, and to establish whether and in what proportions it was derived proximally from the Cunene River or long-distance from the Orange River, this sample set was integrated with 10 beach and dune samples collected from Foz do Cunene to Tombua mostly in January 2016 (Fig. 5), 13 samples collected between 2008 and 2016 from the Cunene River and its Angolan and Namibian tributaries, one Hoarusib River sand, and one fossil dune collected in the terminal tract of the Curoca valley. To monitor sediment transport across the shelf to the deep sea, we have analysed several sediment samples retrieved from the MARUM repository in Bremen (Fig. 1). Offshore samples were collected mostly with a giant box corer just 
97 below the seafloor, on the Walvis Ridge (Meteor Expedition M20/2, Sites GeoB1704 and 98 GeoB1705; Schulz et al., 1992) and seaward of the Cunene mouth (Meteor Expedition M6/6, Sites

99 GeoB1019 to GeoB1022; Wefer et al., 1988). Three samples are from the upper $\sim 8$ meters of two

$10052 \mathrm{~m}$ and $38 \mathrm{~m}$-long cores spanning the last Ma drilled offshore of Baia dos Tigres during ODP Leg

101175 (Site 1080; Wefer et al., 1998). Sixty-one samples were considered overall (full information on

102 sampling sites is provided in Appendix Table A1 and Google Earth file Mocamedes.kmz).

103

104

105

106 Bulk sand was impregnated with araldite, cut into a thin section, and analysed by counting 400 107 points under the microscope (Gazzi-Dickinson method; Ingersoll et al., 1984). Metamorphic rock 108 fragments were subdivided into very low to low-rank metasedimentary (Lms) or metavolcanic 109 (Lmv), and medium to high-rank felsic (Lmf) or mafic (Lmb) categories (Garzanti \& Vezzoli, 110 2003). Sand classification is based on the main components quartz, feldspars and lithic fragments 111 considered if exceeding $10 \% \mathrm{QFL}$ (e.g., a sand is named feldspatho-quartzose if Q $>\mathrm{F}>10 \% \mathrm{QFL}>$ 112 L; Garzanti, 2016).

113 Heavy-mineral analyses were carried out on a quartered aliquot of the bulk sample or $<500 \mu \mathrm{m}$

114 fraction for well sorted eolian and beach sands, and of the $15-500 \mu \mathrm{m}$ class obtained by wet-sieving 115 for fluvial sands. Heavy minerals were separated by centrifuging in sodium polytungstate (density $116 \sim 2.90 \mathrm{~g} / \mathrm{cm}^{3}$ ), and recovered by partial freezing with liquid nitrogen. On grain mounts, 200-250 117 transparent heavy-mineral grains were point-counted at suitable regular spacing under the 118 petrographic microscope to obtain real volume percentages (Galehouse, 1971). On offshore 119 samples, heavy-mineral analyses were carried out by Raman point-counting (Andò et al., 2011) on 120 the $>5 \mu \mathrm{m}$ (silty-clay samples) or $>15 \mu \mathrm{m}$ fraction (sandy-silt to silty-sand samples) obtained by 121 wet sieving. Three beach-placer deposits were analysed by grain-counting, point-counting, and 122 Raman point-counting of bulk-sample slides. Raman spectroscopy analyses, carried out with a 
123 Raman Renishaw inVia, were used to identify opaque Fe-Ti-Cr oxide grains, to assess the chemical

124 composition of detrital pyroxenes and garnets, and to check the determination of altered or dubious 125 transparent heavy minerals (Andò \& Garzanti, 2014).

126 Heavy-mineral concentration, calculated as the volume percentage of total (HMC) and transparent 127 (tHMC) heavy minerals, ranges from extremely poor $(\mathrm{HMC}<0.1)$ and poor $(0.5 \leq \mathrm{HMC}<1)$, to 128 rich $(5 \leq \mathrm{HMC}<10)$, very rich $(10 \leq \mathrm{HMC}<20)$, and extremely rich $(20 \leq \mathrm{HMC}<50)$; placer 129 sands are defined by HMC $\geq 50$. The Source Rock Density (SRD) index of Garzanti \& Andò 130 (2007), defined as the weighted average density of extrabasinal terrigenous grains, was used to 131 detect and correct for hydraulic-controlled concentration of denser minerals. Detrital components 132 are listed in order of abundance throughout the text. The complete petrographic and mineralogical 133 datasets and grain-density measurements are provided in Appendix Tables A2 to A7.

134

137 Chemical analyses of 22 selected samples, including three beach placers, were carried out at ACME 138 Laboratories (Vancouver) on a quartered aliquot of the $63-2000 \mu \mathrm{m}$ class obtained by wet-sieving. 139 Following a lithium metaborate/tetraborate fusion and nitric acid digestion, major oxides and 140 several minor elements were determined by ICP-ES and trace elements by ICP-MS (see $141 \mathrm{http} / /$ acmelab.com for detailed information on adopted procedures, standards used, and precision 142 for elements of group 4A-4B and code LF200).

143 The U-Pb ages of detrital zircons identified by QEMScan electron microscopy (Vermeesch et al., 1442017 ) on heavy-mineral separates of 25 selected samples (mostly $<500$ or $15-500 \mu \mathrm{m}$ size class) 145 were determined at the London Geochronology Centre using an Agilent 7700 LA-ICP-MS system, 146 employing a New Wave NWR193 Excimer Laser operated at $11 \mathrm{~Hz}$ with a $20 \mu \mathrm{m}$ spot size and 2.5$1473.0 \mathrm{~J} / \mathrm{cm}^{2}$ fluence. No cathodoluminesce-imaging was done. Data reduction was peformed using 148 GLITTER 4.4.2 software (Griffin et al., 2008). ${ }^{206} \mathrm{~Pb} /{ }^{238} \mathrm{U}$ and ${ }^{207} \mathrm{~Pb} /{ }^{206} \mathrm{~Pb}$ ages were used for zircons 
149 younger and older than $1100 \mathrm{Ma}$, respectively. No common Pb correction was applied. Grains with $150+5 /-15 \%$ age discordance were discarded, and 1423 concordant ages were obtained overall. 151 Geochemical and geochronological datasets are provided in Appendix Table A8 and Appendix B. 152

TRACING ORANGE SAND TO SOUTHERN ANGOLA

158

This section illustrates the petrographic, mineralogical, and geochronological fingerprints of sandsized sediments from the Orange mouth to southern Angola, focusing on the Cunene catchment (Fig. 6) and Moçamedes Desert (Fig. 7).

\section{Orange River sand}

The Orange River has remained the most prominent sand source to coastal Namibia through most of the Neogene, as inferred from mapping of sedimentary facies and longshore patterns of swell-driven littoral drift (Rogers, 1977; Rogers \& Bremner, 1991 p.24). The Orange catchment includes much of South Africa, where source rocks range from Archean and Paleoproterozoic basements exposed north of its Vaal tributary to the Carboniferous-Lower Jurassic Karoo siliciclastics capped by flood basalts in Lesotho (Fig. 8). Orange sand is feldspatho-litho-quartzose to litho-feldspatho-quartzose, with plagioclase prevailing over K-feldspar, and equally abundant mafic volcanic/subvolcanic and sedimentary (shale/sandstone, carbonate) rock fragments. Heavy-mineral suites are rich and clinopyroxene-dominated, with subordinate opaque $\mathrm{Fe}-\mathrm{Ti}-\mathrm{Cr}$ oxides, epidote, amphibole, and garnet. The remarkably homogeneous clinopyroxene chemistry indicates provenance from Karoo basalts (fig. 5 in Garzanti et al., 2012). U/Pb zircon ages are characterized by prominent Damara and Namaqua peaks at $\sim 0.6$ and $\sim 1.0 \mathrm{Ga}$, with a few older grains clustering at 1.8-2.1 Ga and younger grains at $\sim 0.3 \mathrm{Ga}$ (fig. 1 in Vermeesch et al., 2010).

174

\section{Sand of coastal Namibia}


177 Sand and gravel delivered at the Orange mouth are dragged northward by a powerful longshore 178 drift, whereas mud is largely carried offshore and southward (Rogers \& Rau, 2006). Much of the 179 sand, retained within the breaker zone and moving northward in a $\leq 3 \mathrm{~km}$ wide belt (Spaggiari et 180 al., 2006), bypasses the Sperrgebiet deflation area and accumulates in the Namib Erg (Corbett, 181 1993). Dune and beach sands of the Coastal Namib Erg are feldspatho-quartzose volcaniclastic with 182 rich clinopyroxene-dominated suites including garnet, amphibole and epidote, and display the same 183 clinopyroxene chemistry and zircon-age spectra of Orange sand, indicating that they are derived 184 virtually entirely from the Orange mouth.

185 Littoral sand drift continues to beyond Walvis Bay (Bluck et al., 2007). New corridors of eolian 186 transport form $\sim 350 \mathrm{~km}$ to the north, where coastal orientation changes to SSE/NNW and sand is 187 blown landward to accumulate in the Skeleton Coast Erg (Lancaster, 1982). Relative to Coastal 188 Namib dunes, Skeleton Coast dunes have less volcanic rock fragments, less pyroxene, and more 189 staurolite, garnet, tourmaline, and amphibole (Fig. 9). The geochemical signatures of detrital 190 clinopyroxenes are the same, indicating that only a few are derived locally from Etendeka lavas 191 (fig. 4 in Garzanti et al., 2014). Garnet grains are mostly almandine-pyrope as in Coastal Namib 192 sands, but some almandine-spessartine grains similar to those carried by the Swakop River are 193 found. U-Pb age spectra of detrital zircons show the same prominent Damara and Namaqua peaks 194 as in Orange and Coastal Namib sands. Petrographic, mineralogical, geochemical, and 195 geochronological data concur to indicate that Skeleton Coast dune sand is derived mostly from the 196 Orange River and $20 \%$ from metamorphic and granitoid rocks of the Damara Orogen principally 197 via the Swakop River.

198 Other rivers drain the Damara Orogen (Kuiseb, Omaruru, Ugab, Huab, Hoanib) or the Etendeka 199 volcanic province (Koigab, Uniab), but owing to arid climate their sediment contribution to coastal 200 sand is minor. Summer thunderstorms in the mountainous hinterland may generate high-magnitude 201 floods that last several days, but otherwise they may experience several years of drought. The 202 Hoarusib River farther north receives higher rainfall, and more frequent flows reach the ocean 
203 almost every year (Jacobson et al., 1995). Hoarusib sand is feldspatho-quartzose with moderately 204 rich epidote-amphibole suite. Detrital-zircon ages display a major cluster between 1668 and 1863 $205 \mathrm{Ma}(56 \%$ of ages, with peak around $1850 \mathrm{Ma})$ and a lesser cluster between 1261 and $1423 \mathrm{Ma}(19 \%$ 206 of ages; Appendix B).

207 The Cunene Erg, starting with barchan trains and linear sand streaks north of Cape Frio and 208 bounded to the north by the Cunene River, is characterized by crescentic dunes near the coast and 209 curving linear ridges inland (Goudie \& Viles, 2015).

210

213 The perennial Cunene River (basin area $10^{5} \mathrm{~km}^{2}$, maximum discharge $1000 \mathrm{~m}^{3} / \mathrm{s}$, annual water and 214 sediment fluxes $5 \mathrm{~km}^{3}$ and 9 million tons) is sourced in recently uplifted Angolan highlands (Al215 Hajri et al., 2009), where annual rainfall reaches $1400 \mathrm{~mm}$ and Paleoproterozoic granitoid and 216 metasedimentary rocks are exposed (De Carvalho et al., 2000). The river flows southward along a 217 structurally-controlled depression hosting the westernmost edge of the fossil Kalahari dunefield 218 (Shaw \& Goudie 2002), and finally traverses the Epupa Neoarchean to Mesoproterozoic gneissic 219 basement intruded by one of the largest anorthosite bodies on Earth (dated as $\sim 1.37 \mathrm{Ga}$; Becker et 220 al., 2006), and eventually the high-grade metasediments and granitoids of the western Kaoko Zone 221 (Gray et al., 2008). The sharp westward turn upstream of this final youthful tract points to recent 222 capture of interior drainage, formerly directed towards the Etosha Pan, by a stream eroding 223 backwards from the coast (Haddon \& McCarthy 2005; Goudie \& Viles, 2015). Terrigenous deposits 224 blanket most of the shelf seaward of the Cunene mouth, where phosphorite and glauconite occur 225 (Bremner \& Willis,1993).

226 Tributaries of the Cunene drain different geological domains, and thus carry sand with varied 227 composition (Fig. 9). Angolan tributaries draining the Kalahari paleodesert (e.g., Mucope and 228 Caculuvar Rivers; Fig. 6A) carry recycled quartzose sand with extremely poor heavy-mineral suites 
229 including mainly zircon with tourmaline, epidote, and minor andalusite, staurolite and rutile.

230 Namibian tributaries draining Neoproterozoic siliciclastic rocks (Nosib Group) carry feldspatho-

231 quartzose sedimentaclastic sand with a very poor epidote-amphibole-zircon suite. Tributaries

232 draining the Cunene igneous complex (e.g., Omuhongo River, Fig. 6B) carry quartzo-feldspathic

233 sand with abundant plutonic rock fragments, twinned plagioclase, and a rich epidote-dominated

234 suite including hornblende and pyroxene. Tributaries draining the Epupa metamorphic basement

235 (e.g., Otjinjange River, Fig. 6D) carry feldspatho-quartzose sand with granitoid and high/very-high-

236 rank metamorphic rock fragments including amphibolite, and a very rich hornblende-dominated

237 suite with epidote and minor sillimanite.

238 Trunk river sand in Angola is feldspatho-quartzose with K-feldspar > plagioclase, common twinned

239 microcline and a few siltstone and carbonate rock fragments, reflecting extensive recycling of fossil

240 Kalahari dunes. Heavy-mineral suites change from very poor and zircon-dominated upstream, to

241 amphibole-dominated with common epidote, and minor sillimanite, zircon, tourmaline, apatite,

242 garnet, rutile and andalusite at Ruacana Falls. Sand changes markedly in the final tract, and at

243 Epupa Falls it is notably enriched in plagioclase, plutonic, metamorphic (metasandstone, gneiss,

244 amphibolite) and sedimentary (sandstone/sitlstone) rock fragments, and contains a moderately rich

245 amphibole > epidote suite including kaersutite and oxy-hornblende, green to brown clynopyroxene,

246 hypersthene, and rare olivine (Fig. 6C). At the mouth, Cunene sand reveals extensive mixing with

247 far-travelled sand wind-blown from the coast, as indicated by less plagioclase and more garnet,

248 staurolite and clinopyroxene (Fig. 7A).

$249 \mathrm{U}-\mathrm{Pb}$ zircon ages in Cunene sand at Ruacana Falls are characterized by Eburnean $(46 \%$ of ages 250 between 1710 and $1982 \mathrm{Ma}$ ) and mid-Mesoproterozoic clusters (24\% of ages between 1240 and $2511428 \mathrm{Ma}$ ). At Epupa Falls downstream they change drastically, and display a broad, slightly 252 asymmetrical peak between 1 and $2 \mathrm{Ga}$, centered at $\sim 1.38 \mathrm{Ga}$ (Fig. 10). Zircon-age spectra change 253 drastically again and become trimodal at the mouth, with peaks between 460 and 629 Ma (18\%), 254981 and $1086 \mathrm{Ma}(22 \%)$, and 1758 and $1831 \mathrm{Ma}(18 \%)$. 
255

256

257

258

259

260

261

262

263

264

265

266

267

268

269

270

271

272

273

274

275

276

277

279

280

278 The same feldspatho-quartzose composition with equally abundant lathwork volcanic grains and

\section{Moçamedes Desert sand}

The $\sim 3500 \mathrm{~km}^{2}$ Moçamedes (Baia dos Tigres) dunefield, characterized by the transition from larger crescentic dunes to smaller dunes and linear ridges inland, is sharply delimited to the north by the Curoca River (Fig. 4; Torquato, 1970). A field of coppice dunes (in Arabic nabkhah, "sandy hillocks with pointed top") occurs between Subida Grande and Namibe (Fig. 2E). Dune and beach sands between the Cunene mouth (Fig. 7B) and Subida Grande (Fig. 7C) are feldspatho-quartzose with lathwork volcanic rock fragments and moderately poor to extremely rich garnetclinopyroxene-epidote-amphibole suites including hypersthene, staurolite, and minor tourmaline, zircon, apatite and titanite.

Multimodal U/Pb age spectra of detrital zircons show prominent Damara (29\% of ages between 446 and $685 \mathrm{Ma})$ and Namaqua peaks (26\% of ages between 898 and $1129 \mathrm{Ma})$, Eburnean (16\% of ages between 1.6 and $2.1 \mathrm{Ga}$, peak around $1.74 \mathrm{Ga}$ ) and mid-Mesoproterozoic clusters (14\% of ages between 1164 and $1413 \mathrm{Ma}$, peaks around 1.20 and $1.36 \mathrm{Ga}$ ), minor Early Cretaceous (ages between 120 and $132 \mathrm{Ma}$ ) and Permo-Triassic peaks (ages between 238 and $278 \mathrm{Ma}$ ), and a Neoarchean scatter (Fig. 11). Chemical composition is virtually identical to that of Skeleton Coast dunes, with greater intersample variability controlled by hydrodynamic effects (as discussed below). More phosphorous indicates greater abundance of phosphate grains, largely of organic origin. More Mn, Y, and HREE relatively to Coastal Namib sand reflects progressive concentration of garnet northward along the littoral cell. Petrographic, mineralogical, geochemical, and geochronological data concur to indicate that Moçamedes sands are principally derived from the Orange mouth, with subordinate contribution from the Cunene River (as quantified below). clinopyroxene characterizes the Curoca River upstream of the mouth, indicating overwhelming contribution by windblown sand flushed in the lower course. Very rich heavy-mineral suites do not 
281 include additional amphibole or epidote derived from basement rocks exposed in the upper

282

283

284

285

286

287

288

289

290

291

292

293

294

295

296

297

298

299

300

301

302

303

304

305

306

catchment, and U-Pb zircon-age spectra are hardly distinguished from Moçamedes Desert sand (Fig 9).

\section{From Namibe to Lucira}

Beach sand composition changes abruptly at Namibe (Fig. 7D), where feldspar-rich sand with plutonic, gneissic and amphibolite grains yields a very rich amphibole-epidote suite including clinopyroxene, hypersthene, minor enstatite, olivine, garnet, and rare staurolite. Amphibole and epidote grains are notably angular, and pink zircon grains commonly strongly metamictic, suggesting very prolonged radiometric decay. The bimodal zircon-age spectrum includes Eburnean (44\% of ages between 1727 and $1804 \mathrm{Ma}$ ) and mid-Mesoproterozoic clusters (32\% of ages between 1310 and 1395 Ma; Fig 9).

North of Namibe, the Bero and Giraul Rivers carry feldspar-rich plutoniclastic-gneissiclastic sand with a moderately rich amphibole-epidote suite derived from Angolan basement. Clinopyroxene and hypersthene in Bero sand are most probably derived from the Cunene igneous complex drained in the headwaters; Giraul sand contains less amphibole, more epidote, and minor garnet. The few detrital-zircon ages obtained are Mesoproterozoic in Bero sand and dominantly between 1.7 and 2.0 $\mathrm{Ga}$ in Giraul sand. Additional clinopyroxene may be derived from Cretaceous volcanic rocks exposed in the lower course of both rivers (Alberti et al., 1992).

Feldspar-rich feldspato-quartzose composition characterizes all beach and river sands farther north, with poor to rich epidote-amphibole suites documenting provenance from basement rocks (Fig. 7E). Mainly brown, subrounded augitic clinopyroxene or zircon associated with garnet, titanite, rutile and apatite occur locally (Mariquita and Chapeu Armado beaches), suggesting subordinate supply from basaltic and siliciclastic rocks of the Namibe Basin exposed close to the coast (Strganac et al., 2014; Gindre-Chanu et al., 2016). 
307

308

309

310 Walvis Ridge samples (water depths $-399 \mathrm{~m}$ and $-642 \mathrm{~m}$ ) are medium silts with a little sand fraction

311 dominated by tests of planktonic and subordinately benthic foraminifers. Coarse-silt-sized

312 siliciclastic detritus, glaucony and phosphate grains are all very minor. The sand fraction in samples

313 collected offshore of the Cunene mouth (water depths from -75 m to $-173 \mathrm{~m}$ ), consisting chiefly of

\section{Offshore sediments} green glaucony to brown-greenish glauco-phosphorite grains and including benthic foraminifers, echinoid fragments and phosphate clasts, increases progressively oceanward and consists virtually entirely of $\sim 2 \phi$-sized, subangular to subrounded, deep-green glaucony grains at $-551 \mathrm{~m}$ depth (fig. 7 in Garzanti et al., 2017). Terrigenous siliciclastic detritus decreases progressively seaward in abundance from $\sim 70 \%$ to $\sim 3 \%$, and in size from very fine sand to coarse silt. Heavy-mineral concentration in the $>15 \mu \mathrm{m}$ fraction remains remarkably constant, and similar to that of Skeleton Coast dune sand at any depth (HMC $\sim 7$, tHMC 6). In all six samples, heavy minerals are mostly clinopyroxene (Appendix Table A5), with subordinate epidote and blue-green amphibole, minor garnet, titanite, apatite, hypersthene, zircon, rutile, and rare tourmaline, staurolite and sillimanite. Platy micas are few (2-5\%). Vivianite occurs at depths between $-110 \mathrm{~m}$ and $-551 \mathrm{~m}$ offshore of the Cunene mouth; celestite and carbonate grains occur in the shallower Walvis Ridge sample.

The feldspatho-quartzose terrigenous fraction of offshore samples, including a few mafic volcanic grains and a heavy-mineral suite as rich in clinopyroxene as in Skeleton Coast sand, indicates dominant provenance from the Orange mouth (Fig. 12). The notably lower abundance of opaque Fe-Ti-Cr oxides and garnet suggests preferential segregation of ultradense minerals in beach placers, although offshore samples have the same amount of low-density amphibole as Skeleton Coast dunes. Epidote shows a regular relative increase oceanward, from $6 \pm 2 \%$ tHM in Skeleton Coast sands, to $12 \pm 2 \%$ tHM in shelfal sediments, to $18 \pm 3 \%$ tHM in deeper-water sediments (correlation coefficient 0.93 ). This suggests mixing in increasing proportions with an epidote-rich 
333 detrital population possibly supplied by local rivers draining the Kaoko belt (e.g., Hoarusib River).

334 Low amphibole and negligible hypersthene contents rule out contributions from the Cunene River 335 even for the sample collected only $\sim 13 \mathrm{~km}$ northwest of the Cunene mouth.

336 ODP Site 1080 samples were collected at $\sim 0.9 \mathrm{~m}$ and $\sim 8.1 \mathrm{~m}$ below seafloor at the top of a 337 hemipelagic section consisting of moderately bioturbated, olive-gray, diatom-bearing silty clays 338 with varying abundance of nannofossils and foraminifers. Radiolarians, silicoflagellates, plant 339 remains, particulate organic matter, glauconitic peloids, and authigenic pyrite also occur. The 340 Matuyama/Brunhes boundary and the onset of the Jaramillo Subchron occur at $\sim 9.5 \mathrm{~m}$ and $\sim 41 \mathrm{~m}$ 341 below seafloor, suggesting that the upper Quaternary record is largely missing (Wefer et al., 1998). 342 Estimated ages for the studied samples range between $<0.4 \mathrm{Ma}$ and $\sim 0.7 \mathrm{Ma}$. The subordinate 343 feldspar-rich feldspatho-quartzose terrigenous fraction yielded moderately rich to rich heavy344 mineral assemblages either clinopyroxene-dominated and virtually identical to MARUM samples 345 collected on the Walvis Ridge and offshore of the Cunene mouth, indicating provenance mostly 346 from the Orange River (younger sample), or including clinopyroxene, epidote, amphibole and 347 garnet, and comparing most closely with beach and dune sands of the southernmost Moçamedes 348 Desert, thus revealing subordinate additional supply from the Cunene River (two older samples). 349 Vivianite and celestite occur.

350

\section{THE ORIGIN OF GARNET AND MAGNETITE PLACERS}

352

353 This section documents the marked intersample variability (i.e., difference in mineralogical and 354 chemical composition among diverse beach and dune samples) observed in the Moçamedes Desert, 355 and discusses similarities and differences among placer deposits formed along the Atlantic coast 356 from the Namib Erg to Lucira (Fig. 13). Progressive heavy-mineral enrichment in beach or dune 357 sands is caused principally by selective removal of larger low-density grains, which project higher 358 above the bed and hence have smaller pivoting angles and experience greater flow velocities and 
359 drag forces than settling-equivalent smaller and denser grains (Komar, 2007). Beach placers 360 consisting mainly of ultradense minerals are formed during major storms, when large volumes of 361 sand are rapidly removed offshore (Silvester, 1984). Being a most abundant transparent ultradense 362 mineral, garnet is commonly dominant in placer lags, but even garnet is removed when 363 hydrodynamic effects are carried to the extreme. Placer deposits are then dominated by similarly 364 widespread but even denser opaque Fe-Ti-Cr oxides, the most common of which is generally 365 magnetite followed by ilmenite (Garzanti et al., 2009).

366 The grain density of placer sands, containing minor amounts of quartz and feldspars, exceeds the 367 density of the densest rocks known, ranging between $3.5-4.0 \mathrm{~g} / \mathrm{cm}^{3}$ for garnet placers to $\sim 4.5 \mathrm{~g} / \mathrm{cm}^{3}$ 368 for magnetite placers. "Semi-placers", enriched in dense grains to a lesser extent, are characterized 369 by very rich to extremely rich heavy-mineral concentrations and by grain densities typically 370 between 2.8 and $3.0 \mathrm{~g} / \mathrm{cm}^{3}$. Conversely, heavy minerals are notably depleted by hydrodynamic 371 processes in "anti-placers", the grain density of which is thus significantly lower than akin deposits 372 and close to the density of quartz $\left(2.65 \mathrm{~g} / \mathrm{cm}^{3}\right)$. "Neutral" sand is defined by the composition that 373 sand would have ideally everywhere in the absence of such selective-entrainment effects.

377 Garnet placers occur commonly on beaches of Namibia, and are widespread along the terminal tract 378 of the Orange littoral cell in southern Angola (Fig. 2). This is particularly surprising when 379 considering that garnet concentration is estimated to be only $0.2 \pm 0.1 \%$ in Orange River and Coastal 380 Namib sands, and even much less in Cunene sand ( 0.02\%). An additional source of garnet, 381 associated with staurolite, is represented by medium-grade Damara metasediments drained by the 382 Kuiseb (garnet concentration $0.2 \%$ ), Swakop (0.5 $\pm 0.2 \%$ ), Omaruru (0.2\%), Ugab $(0.1 \%)$ and Huab $383(0.4 \%)$ Rivers. Garnet is in fact observed to increase in abundance from the northern part of the 384 Coastal Namib Erg to the beaches of central Namibia, where it commonly represents the most 
385 abundant and even dominant transparent heavy mineral. Garnet concentration rises to $0.8 \pm 0.3 \%$ in

386 Skeleton Coast dunes, which documents a significant increase relative to the mixture of contributing

387 sources and thus a progressive enrichment in the direction of longshore transport. Concentration of 388 opaque Fe-Ti-Cr oxides is broadly constant along the littoral cell, ranging from $0.8 \pm 0.5 \%$ in Orange 389 sand to $0.93 \pm 0.02 \%$ in Skeleton Coast dunes, and not much different in sands of the Cunene $(0.8 \%)$ 390 and Namibian rivers draining the Damara orogen $(1 \pm 1 \%$ for Kuiseb, $0.5 \pm 0.5 \%$ for Swakop, $0.2 \%$ 391 for Omaruru, $0.9 \pm 0.4 \%$ for Ugab, and $0.1 \%$ for Huab).

392 In our samples from the Moçamedes Desert, garnet increases further to become the most abundant 393 and locally dominant heavy mineral. Concentrations of both garnet and opaque Fe-Ti-Cr oxides 394 vary over two full orders of magnitude, reaching $17 \%$ and $20 \%$ of dune sand and three times more 395 in beach placers.

396

399 Three deep red to black foreshore sands, two from the Moçamedes Desert and one from Bentiaba 400 beach, were analysed (results given in Appendix Table A4). Heavy-mineral concentration ranges 401 from 95 to $99 \%$, with garnet and opaque Fe-Ti-Cr oxides representing $48 \%$ and $42 \%$ of the Praia do 402 Navio placer, and $32 \%$ and $62 \%$ of the Vanesinha placer, respectively. Torquato (1970) reported 403 high concentration of garnet (42\%) and opaque Fe-Ti-Cr oxides (21\%) from a beach placer at Praia 404 Amelia ( $\sim 5 \mathrm{~km}$ east of Namibe). Zircon, clinopyroxene, staurolite, epidote, rutile, titanite, 405 hypersthene, monazite, and amphibole represent together $6 \%$ of the sample, quartz $<2 \%$, and 406 feldspar $<1 \%$. Detrital garnets resulted to be all pyralspites, mostly almandine-pyrope, some 407 almandine, a few spessartine, and several almandine with either spessartine or both pyrope and 408 spessartine molecule. On classical ternary plots, compositions overlap widely those of garnets in 409 Skeleton Coast dunes, confirming common, long-distance provenance from the south (dataset and 410 plots shown in Appendix Table A6 and Figure A1). 
411 Opaque Fe-Ti-Cr oxides make up $89 \%$ of the Bentiaba placer (Fig. 3B), where garnet is rare. Zircon 412 and epidote, together with amphibole, monazite, rutile, and titanite represent $7 \%$ of the sample. 413 Quartz and feldspar are $\leq 1 \%$ each.

414 Grain density measured with a hydrostatic balance (method described in Garzanti et al., 2012b, 415 results shown in Appendix Table A7) is $4.17 \pm 0.05 \mathrm{~g} / \mathrm{cm}^{3}$ for the Praia do Navio garnet-magnetite 416 placer, $4.40 \pm 0.01 \mathrm{~g} / \mathrm{cm}^{3}$ for the Vanesinha magnetite-garnet placer, and $4.61 \pm 0.04 \mathrm{~g} / \mathrm{cm}^{3}$ for the 417 Bentiaba magnetite placer. In the northern Moçamedes Desert, grain density increases from $4182.67 \pm 0.01 \mathrm{~g} / \mathrm{cm}^{3}$ in beach sand slightly depleted in heavy minerals (Fig. 2C), to $2.78 \mathrm{~g} / \mathrm{cm}^{3}$ in sand 419 collected on beach berms enriched in heavy minerals (Fig. 2A,B), and to $2.82 \pm 0.01$ and $3.26 \pm 0.01$ $420 \mathrm{~g} / \mathrm{cm}^{3}$ in eolian sands collected on dune crests (Fig. 5C,D). North of Namibe, approximately neutral 421 river and beach sands have a grain density of $\sim 2.67 \mathrm{~g} / \mathrm{cm}^{3}$ (Figs. $3 \mathrm{C}_{1}, 7 \mathrm{E}$, and $7 \mathrm{E}_{1}$ ), increasing to $422 \quad 2.77 \pm 0.03 \mathrm{~g} / \mathrm{cm}^{3}$ in the Inamangando outer berm semi-placer notably enriched in Fe-Ti-Cr oxides 423 (Figs. $3 \mathrm{C}_{4}$ and $7 \mathrm{E}_{2}$ ).

424

427 Beach placers in the Moçamedes Desert and north of Namibe display different patterns of 428 enrichment in chemical elements hosted in dense and ultradense minerals, reflecting different 429 sediment provenance (Fig. 14). Relative to neutral beach sand, Moçamedes beach placers are 430 enriched by up to two orders of magnitude in $\mathrm{Zr}$ and $\mathrm{Hf}$, by factors of 40-60 in Ti, Ta, and Mn, of 431 20-30 in Th, U, V, Fe, and Sn, and of 10-15 in Sc and Co. Cr and LREE are enriched by less than 432 one order in magnitude, whereas enrichment in HREE ramps up with increasing atomic weight 433 from $\leq 10$ times for $\mathrm{Gd}$ to $\sim 40$ times for $\mathrm{Lu}$. The Eu anomaly ranges between 0.23 and 0.32 . REE 434 patterns, similar to those displayed by Coastal Namib beach placers (Fig. 14A), reflect the 435 progressive enrichment principally in garnet and subordinately in zircon, epidote, titanite, Fe-Ti-Cr 
436 oxides, and apatite (Fig. 14C). Markedly negative loss on ignition reflects strong concentration of 437 magnetite.

438 The Bentiaba beach placer is enriched by more than two orders of magnitude in Th and LREE, by 439 factors up to 80 in $\mathrm{Zr}$ and $\mathrm{Hf}$, up to 50-70 in $\mathrm{U}$, Ti, $\mathrm{Nb}$, and $\mathrm{Fe}$, up to $40-50$ in $\mathrm{V}$, Ta, and $\mathrm{Cr}$, up to $440 \quad 30-40$ in $\mathrm{Mn}$, up to $\sim 10-15$ in $\mathrm{Co}, \mathrm{Sn}$, and $\mathrm{P}$, and up to 5-10 in $\mathrm{Sc}, \mathrm{W}, \mathrm{Ni}$, and $\mathrm{Pb}$. Enrichment in 441 HREE steps down with increasing atomic weight from $\sim 90$ times for Gd to 60 times for Lu (Fig. 442 14B). The Eu anomaly is 0.21 . The REE pattern is controlled principally by monazite and epidote, 443 and subordinately by titanite, Fe-Ti-Cr oxides, and zircon (Fig. 14D). Very markedly negative loss 444 on ignition reflects extreme concentration of magnetite.

445 The amount of rare ultradense minerals hosting large amounts of specific trace elements (e.g. $\mathrm{Zr}$ 446 and Hf in zircon, LREE and Th in monazite) can be calculated independently from chemical data 447 (approach and results illustrated in Appendix A2). Beaches and dunes in the Skeleton Coast and 448 Moçamedes Desert are estimated to contain $\sim 0.04 \%$ zircon, more than sands of the Orange River 449 ( $\sim 0.02 \%)$, of Coastal Namib beaches and dunes $(0.01-0.03 \%)$, and of rivers draining the Damara 450 orogen in central Namibia ( $\sim 0.02 \%)$, supporting progressive northward concentration of ultradense 451 minerals in coastal sediments of the Orange littoral cell. Zircon concentration is estimated to reach $452 \sim 1.5 \%$ in Coastal Namib and Bentiaba placers and $\sim 2.9 \%$ in Moçamedes placers, monazite $\sim 0.03 \%$ 453 in Coastal Namib placers, $\sim 0.05 \%$ in Moçamedes placers, and $0.7 \%$ in the Bentiaba placer.

457 Moçamedes Desert sand is largely derived long-distance from the Orange mouth, after an ultralong 458 littoral transport exceeding $1500 \mathrm{~km}$. Sand sources other than the Orange River are present in 459 central Namibia, the most significant of which being the Swakop River, estimated to contribute $46020 \pm 3 \%$ of the sand accumulated in the Skeleton Coast dunefield of northern Namibia (Garzanti et 461 al., 2014). Moçamedes dunes and beaches contain more metamorphic rock fragments, epidote and 
462 amphibole, and less clinopyroxene than Skeleton Coast dunes. Additional supply from the permanent Cunene River, not identified previously owing to limited data, is thus significant and it is

464 quantified tentatively here by forward mixing models based on integrated bulk-petrography and 465 heavy-mineral datasets (mathematical approach illustrated in Appendix A1). Problems in the 466 calculation are caused by the great intersample compositional variability of dune and beach sands, 467 by mixing with far travelled wind-blown sand in the terminal tract of the Cunene River, and by 468 potential additional contribution from the Hoarusib River in northern Namibia.

469 As a first step, a robust estimate of the composition of Moçamedes Desert sand is obtained by 470 averaging the observed composition of our 14 beach and dune samples corrected by using the 471 provenance package of Vermeesch et al. (2016) to a grain density of $2.70 \mathrm{~g} / \mathrm{cm}^{3}$, close to that 472 estimated for both Skeleton Coast Erg (SRD $2.71 \pm 0.02 \mathrm{~g} / \mathrm{cm}^{3}$ ) and Cunene sands (SRD 2.69). The 473 composition thus obtained was compared mathematically with three contributing end-members, 474 represented by Cunene sand at Epupa Falls, Skeleton Coast Erg sand (proxy for longshore drifting 475 sand), and Hoarusib River sand (also proxy for central and western zones of the Kaoko belt drained 476 by the Cunene River between Epupa Falls and the edge of the Cunene Erg). The simple forward 477 mixing model thus constructed suggests that Moçamedes Desert sand is derived $\sim 74 \%$ from 478 longshore drift, $~ 18 \%$ from the Cunene River upstream of Epupa Falls, and 8\% from the Hoarusib 479 River and/or Kaoko belt rocks drained in the terminal tract of the Cunene. Cunene sand at the river 480 mouth is calculated to be derived $\sim 64 \%$ from the Cunene upstream of Epupa Falls, $\geq 24 \%$ from 481 eolian sand of the Cunene Erg, and $\leq 12 \%$ from the Kaoko Belt drained in the terminal tract.

482 Diverse trials performed with slightly different end members (e.g., determined as the mean, 483 weighted-mean, or median composition of all replicate samples, or of selected replicate samples 484 only), or with a partial set of parameters (e.g., petrographic or heavy minerals only), suggest that 485 long-distance littoral drift contributes between $65 \%$ and $80 \%$ of Moçamedes sand. If long-distance 486 littoral drift is derived $20 \pm 3 \%$ from the Swakop and the rest from the Orange, then Moçamedes 487 Desert sand is derived $58 \pm 7 \%$ from the Orange, $15 \pm 3 \%$ from the Swakop and other rivers draining 
488 the inland branch of the Damara Orogen in central Namibia, 20-25\% from the Cunene River 489 upstream of Epupa Falls, and $\leq 5 \%$ from the Hoarusib River. Between half and two-thirds of 490 Moçamedes Desert sand is derived ultralong-distance from the Orange River, only between a fifth 491 and a fourth from the Cunene River.

492

\section{THE END OF THE ORANGE SAND HIGHWAY}

Northward littoral drift from the Orange mouth represents the major source of sand along the hyperarid Atlantic coast to as far as southern Angola. Beaches at Curoca mouth and Subida Grande have the same petrographic composition and heavy-mineral suites as Moçamedes Desert sand, indicating that littoral drift continues north of Tombua. Sand supply from the Curoca River, which flows along the northeastern edge of the Moçamedes Desert where it is choked by eolian sand blown from the south, is undetected. The garnet placer reported by Torquato (1970) at Praia Amelia represents the northernmost testimony of the Orange littoral cell, which terminates abruptly at 15²’'S (Fig. 15).

Beach sand collected at Namibe only $\sim 5 \mathrm{~km}$ east of Praia Amelia has radically different composition. Abundant angular amphibole and commonly metamictic zircon grains yielding ages not younger than $1.3 \mathrm{Ga}$ reveal dominant local contribution from the Bero River. Feldspar-rich sands with epidote-amphibole heavy-mineral suites and unimodal zircon-age spectra with Eburnean peak all along the coast north of Namibe indicate that sediment is not derived alongshore from the south, but contributed from rivers draining basement rocks exposed in adjacent Angolan highlands. The Orange sand trace is thus suddenly lost at Namibe. This is highlighted by the abrupt change in petrographic and mineralogical signatures (Fig. 9) as well as in age-spectra of detrital zircons, indicating bimodal provenance from crystalline rocks of the Namaqua and Damara belts in the south and from the Paleoproterozoic Angola Block in the north (Fig. 11). 
516 The average amount of time needed for sand to cover the entire distance from the Orange mouth to

517 Namibe is hard to constrain even roughly. With a constant longshore velocity of $1 \mathrm{~mm} / \mathrm{s}$ (e.g., 518 Komar, 1977), without any pause or detour, a single sand grain could theoretically complete the 519 Orange sand highway in 57 years only. With a typical alongshore displacement velocity of an 520 accretion/erosion wave, estimated to range between 0.5 and $4 \mathrm{~km} / \mathrm{a}$ (Inman \& Jenkins, 2005), the 521 minimum time required would range between 3600 and 450 years. On the other extreme, a rough 522 extrapolation of the residence time in the $\sim 600 \mathrm{~km}$-long coast of the Namib Erg, assessed from 523 cosmogenic nuclides to be of at least one million years (Vermeesch et al., 2010), would give a 524 figure of at least three million years. A travel time plausibly longer than Milankovian frequencies 525 would involve complex eustatically controlled sand cycling from the littoral to the eolian 526 environment and back, which occurred repeatedly during the Pleistocene (Bluck et al., 2007; 527 Compton \& Wiltshire, 2009).

528 As documented by the Tsondab Sandstone, which underlies most of the modern Namib Erg and 529 represents its Miocene predecessor characterized by impressively similar sedimentological and 530 mineralogical features (Ward, 1988; Besler, 1996; Kocurek et al., 1999), northward littoral sand 531 drift from the Orange mouth was well established by the middle Miocene, and has been maintained 532 for the last $15 \mathrm{Ma}$ at least (Lancaster, 2014). Swell-driven longshore dispersal may have originated 533 much earlier, in Eocene or possibly Late Cretaceous times (Bluck et al., 2007), and might even have 534 persisted since the Albian early opening of the South Atlantic (Quesne et al., 2009).

535 Coastal dunefields of Namibia and southern Angola cover an area of $\sim 51,000 \mathrm{~km}^{2}$ overall 536 (Lancaster, 2014), and host a total volume of sand between 1100 and $1600 \mathrm{~km}^{3}\left(773-1020 \mathrm{~km}^{3}\right.$ in 537 the Namib Erg; Bullard et al., 2011), more than 90\% of which (i.e., 1000-1500 $\mathrm{km}^{3}$ ) derived from 538 the Orange River. Let us assume a northward longshore sand flux between $10^{5}$ and $10^{6} \mathrm{~m}^{3} /$ a (i.e., $5390.27-2.710^{6} \mathrm{t} / \mathrm{a}$ ), which appears as a reasonable range considering both net longshore transport 540 rates in South Africa (Schoonees, 2000) and long-term total (mud + sand) Orange sediment flux 
541 (estimated at $11 \pm 210^{6} \mathrm{t} / \mathrm{a}$ from cosmogenic measurements by Vermeesch et al., 2010). If littoral 542 drift had continued regularly for $15 \mathrm{Ma}$, then the total amount of sand displaced along the littoral 543 highway would range between 1500 and $15,000 \mathrm{~km}^{3}$. Orange contribution to modern coastal deserts 544 matches the lower figure, whereas the higher one is much too high even if the volumes of sand 545 stored in paleodunes of the Tsondab Sandstone (maximum thickness $220 \mathrm{~m}$; Ward, 1988) is taken 546 into account. The volume loss of Orange-derived sand to the deep sea through time, presumably 547 enhanced during Pleistocene lowstands, may thus amount to several thousands of $\mathrm{km}^{3}$. A direct 548 evidence that a significant fraction of northward drifting sand is lost in deep waters offshore even 549 during the present highstand stage is given by the mineralogy of sediments deposited recently in the 550 deep sea from the Walvis Ridge to north of the Cunene mouth (Fig. 12).

551 Considering that Orange suspended load was reduced by a factor of at least 5 after the construction 552 of big dams along its course by the end of the 1970s (Rooseboom \& Harmse, 1979; Bremner et al., 553 1990), and that bedload must have decreased even more drastically, the Orange sand highway is 554 bound to be affected profoundly by human-built infrastructures. How soon and to what extent, and 555 whether and when it will be eventually disrupted, it is however hard to establish. Although the 556 existence and persistence in time of ultralong littoral cells is of great relevance for the accuracy of 557 paleogeographic reconstructions, to the best of our knowledge no similar sediment-routing system 558 has been documented from the geological record so far.

559

560 561

562 563

564 565 566

\section{Why and how the Orange sand highway ends}

Eolian sand transport on land is effectively hampered and eventually blocked by deep river valleys with perennial flow or where floods are sufficiently frequent to flush eolian sand to the sea (Lancaster, 1982). This occurs at the northern edge of all four coastal dunefields of Namibia and southern Angola. The Namib Erg is terminated by the Kuiseb River, and eolian sand transport finally stopped by the Swakop River. The Skeleton Coast Erg is terminated by the Hoarusib River, 
567 and eolian sand transport stopped by the Khumib River. The Cunene Erg is terminated by the 568 Cunene River, and the Moçamedes Erg by the Curoca River. Northward sand drift, however, 569 continues undisturbed in the littoral zone, and where the coast takes an appropriate direction a new 570 linear corridor is formed along which sand is blown from the sea to feed the next dunefield inland.

571 The cause for the termination of the Orange littoral cell is thus to be found offshore rather than on 572 land. Considering that strong northward longshore currents and littoral drift continue all along the 573 Angolan coast to far north of the Congo mouth (Guilcher et al., 1974; Dinis et al., 2016), the abrupt 574 end of the Orange littoral cell at Namibe cannot be ascribed primarily to a change in atmospheric or 575 oceanic circulation associated with the Angola-Benguela front (Fig. 1). A key factor, instead, is the 576 physiography of the shelf (Bremner \& Willis, 1993; Rogers \& Rau, 2006).

577 Huge sediment volumes can be transported both along and across the continental shelf, which 578 represents the interface between terrestrial sediment sources and deep-sea sediment sinks. Detrital 579 supply from large rivers is a major driver of shelf-margin growth (Carvajal et al., 2009). Along 580 orthogonal-rifted segments of passive margins characterized by relative tectonic stability and major 581 long-lived river systems (Potter, 1978; Cox, 1989), the distance between the coast and the 582 shelfbreak may grow larger in time, until a wide stretch of shallow, mildly sloped sea-floors swept 583 by swell waves may limit permanent sediment loss offshore and allow littoral transport over even 584 very long distances (Silvester \& Mogridge, 1970). Conversely, along dynamically-uplifted or 585 transform-rifted active or passive continental margins the shelf is generally much narrower, and 586 coastal sediments can be conveyed directly to the deep sea wherever a canyon reaches close to 587 shore (Covault \& Fildani, 2014). Abrupt termination of littoral cells at canyon heads, where drifting 588 sand is efficiently funneled away from the shoreline and dragged to the deep sea by turbidity 589 currents, is widely documented (e.g., Patsch \& Griggs, 2007). The most likely cause for the 590 termination of the ultralong Orange littoral cell in the Namibe oblique rifted-margin segment 591 (Guiraud et al., 2010) is thus the presence of submarine canyons connected with the Curoca and 592 Bero River mouths (Fig. 4). A river valley is able to terminate a littoral cell only where it connects 
593

594

595

596

597

598

599

600

601

602

603

604

605

606

607

608

609

610

611

612

613

614

615

616

$617 \sim 10 \mathrm{~km}$ offshore of the northern Moçamedes Desert, and to a few $\mathrm{km}$ at most from Tombua to

618 Namibe, where the $-150 \mathrm{~m}$ isobath lies within $1 \mathrm{~km}$ from the coast at the head of the Curoca and

underwater to a submarine canyon across a narrow shelf, thus representing an effective sedimenttrapping trench dug all across the continental margin.

\section{Placer formation at the end of the Orange sand highway}

It has been stated that "sea level changes are the prime factor influencing placer mineral concentration processes and the regional distribution and preservation of placer deposits on the modern shelf" (Kudrass, 2000 p.9). Placer deposits, however, may form during both transgressive and regressive stages, and the relationships with eustatic fluctuations and shelf physiography are complex (Roy, 1999; Dillenburg et al., 2004; Dinis \& Soares, 2007). Exploration of the continental shelf worldwide has documented a decrease in heavy-mineral concentration typically by an order of magnitude with water depth (fig. 6 in Kudrass, 1987), and a partitioning of ultradense minerals in beach placers and of slower-settling "more mobile" minerals such as amphiboles or micas offshore (Cascalho \& Fradique, 2007). If the littoral zone is sufficiently shallow and wide, then the antiplacer sand fraction selectively entrained seaward and deposited to build an offshore bar during storm events can be dragged again landward by swell waves (Silvester, 1984). The original composition of beach sand is thus restored. Permanent enrichment in ultradense minerals in coastal sediments requires net sediment removal and deposition by storm-surge or turbidity currents in the deep sea beyond the reach of swell waves. Shelf bathymetry and width thus exert a fundamental control not only on the sediment budget of coastal areas but also on the partitioning of detrital minerals between the coast and the deep sea.

In southwestern Africa, the width of the continental shelf reaches 180-200 km offshore of the Orange mouth, ranges between 150 and $100 \mathrm{~km}$ offshore Namibia as far as the Walvis Ridge, and it is reduced to $40-45 \mathrm{~km}$ in the north as far as Baia dos Tigres. Farther north it decreases rapidly to 54 
619 Bero canyons (Fig. 15). Along the coast of Namibia, where the shelf is wide, only subtle trends in 620 mineralogical composition are observed. Gradual loss of platy amphibole relative to equant 621 ultradense garnet (fig.10 in Garzanti et al., 2015b) suggests that a fraction of the sand enriched in 622 slower-settling minerals has been lost to the deep sea along the Orange littoral cell, possibly largely 623 during Pleistocene lowstands. Sediments collected offshore of the Cunene mouth are depleted in 624 ultradense garnet and Fe-Ti-Cr oxides by an order of magnitude, but heavy-mineral concentration 625 remains remarkably constant after correcting for mixing with intrabasinal calcareous, glaucony, and 626 phosphate grains. The order-of-magnitude decrease in heavy minerals in deep-water sediments 627 sampled seaward of the shelf edge is thus ascribed to mixing with intrabasinal grains rather than to 628 hydraulic-sorting effects.

629 Along the coastal stretch north of Baia dos Tigres, where a well defined scarp connects the 630 continental slope with the abyssal plain, beach and dune sands become markedly enriched in garnet 631 and Fe-Ti-Cr oxides (Fig. 2A,B). The sharp boundary between cream-yellow dunes and dark-red 632 dunes rich in ultradense minerals, running NNE/SSW and intersecting the coast at $\sim 16^{\circ} 23^{\prime} \mathrm{S}$ as 633 clearly seen in Fig. 5, suggests an abrupt northward decrease in sand availability (Courrech du Pont 634 et al., 2014). Yellow dunes in the southeast are in fact much larger, predominantly transverse, and 635 reach elevations increasing from some tens of meters near the coast to $250-280 \mathrm{~m}$ inland, whereas 636 red parabolic dunes to the north occur in a low elevation area with wetlands and are mostly $<10 \mathrm{~m}-$ 637 high, indicating limited sand supply (Reffet et al., 2010; Gao et al., 2015). Along the low-altitude, 638 sub-rectilinear costal stretch north of Baia dos Tigres, coarser-grained low-density minerals are 639 selectively entrained offshore during storms and lost in deep waters beyond the narrow shelf, 640 leaving coastal sands strongly depleted in lighter and less dense quartz and feldspars and relatively 641 enriched in darker ultradense minerals (Fig. 5C,D). The formation of garnet-magnetite foreshore 642 placers implies that most of the sand $(\geq 98 \%$ and $\geq 99 \%$ for the Praia do Navio and Vanesinha 643 placers, respectively) has been removed temporarily from the beach and parked offshore. The 
644 comparison with the average mineralogy of Moçamedes Desert sand suggests that between half and

645 four/fifths of longshore-drifting sand has been transferred permanently to the deep ocean.

646 Irreversible sand loss is accentuated in the coastal stretch between Tombua and Namibe (Fig. 647 2D,E), where the bulk of drifting sand is captured by the Curoca and Bero canyons and the $~ 1800$ 648 km-long Orange sand littoral highway eventually comes to a sudden end (Fig. 15). No major 649 canyon is apparently connected with the Cunene mouth (Fig. 4), possibly because the river used to 650 flow southward to the Etosha paleolake and its lower course is recent, and/or because the mouth is 651 choked by longshore drifting sand.

652 Along the Atlantic coast of southern Africa there is hardly a place where the shelf is as narrow as in 653 the oblique rifted-margin segment between Namibe and Lucira, where a nearshore positive gravity 654 anomaly suggests the presence of underplated basaltic magma or denudated mantle associated with 655 Moho uplift (Guiraud et al., 2010). Along this coastal stretch, sediment supply is limited because 656 climate is dry and the adjacent Bié-Huila dome is drained by the Cunene River to the south and by 657 the Cuanza and other rivers feeding the Benguela and Cuanza basins to the north. The outer berm 658 commonly undergoes erosion, it is consequently enriched in heavy minerals (Fig. 3C), and 659 foreshore magnetite placers are formed (Fig. 3B), which confirms the close relationship among 660 sediment supply, shelf width, and occurrence of placer deposits. The observed enrichment in Fe-Ti661 Cr oxides (Fig. 7 $\mathrm{E}_{2}$ ) indicates that more than half of the sand originally deposited on the outer berm 662 at the Inamangando river mouth has been entrained temporarily or permanently offshore.

663

\section{CONCLUSIONS}

665

666 In the Khoekhoe language used by Nama people, the word Namib designates the "vast place of 667 nothingness" facing the Atlantic Ocean in southwestern Africa. All along this desert stretch of 668 coastal land, from southern Namibia to Namibe in southern Angola, sand derived from as far as 669 basaltic Lesotho highlands via the Orange River is transported for $\sim 1800 \mathrm{~km}$ under the persistent 
670 action of swell-driven waves. Orange sand, making up $99 \%$ of the Coastal Namib Erg and $~ 80 \%$ of 671 the Skeleton Coast Erg, is still predominant in beaches and dunes of the Moçamedes Erg, where 672 contribution from the perennial Cunene River draining the Kalahari paleodesert in the upper course 673 and up to high-grade metamorphic and plutonic rocks in the lower course does not exceed $25 \%$. 674 North of Baia dos Tigres, the continental shelf becomes so narrow that coarser lower-density 675 minerals selectively entrained during higher-energy events are lost offshore, and beach and dune 676 sands onshore are consequently enriched in ultradense garnet and Fe-Ti-Cr oxides. The longest 677 submarine sand highway documented on Earth so far extends for a few tens of kilometers north of 678 the Curoca River and terminates at Namibe, where sand composition and U-Pb age spectra of 679 detrital zircons change abruptly, documenting local fluvial supply from Paleoproterozoic basement 680 exposed in adjacent highlands. The mineralogy and geochemistry of placer lags also changes and 681 their REE patterns, influenced by the concentration of garnet all along the Orange cell, here largely 682 reflect the concentration of monazite.

683 In southwestern Africa, eolian sand transport on land is blocked repeatedly by river valleys cutting 684 perpendicularly toward the coast, as seen at the northern edges of all four Namib, Skeleton Coast, 685 Cunene, and Moçamedes Ergs. Longshore transport is however unaffected, and continues in 686 shallow waters offshore. Littoral sand drift ends only where the Curoca and Bero river valleys are 687 associated with the head of submarine canyons reaching close enough to shore to form effective 688 sediment-trapping trenches extending all across the narrow rifted margin. Large dams built along 689 the course of the Orange River, with consequent drastic reduction in bedload transport, is bound to 690 affect a sediment conveyor belt established since the Miocene at least and perhaps even since the 691 Cretaceous initial opening of the South Atlantic, and to modify the sediment budget of the Atlantic 692 coast to as far north as southern Angola.

693 Longshore transport of large sediment volumes in the shallow sea, from the mouth of big rivers 694 over distances of a thousand kilometers and more, occurs on our planet today, and has occurred 695 with all likelihood in the past as well. And yet to the best of our knowledge no similar sediment- 
696 routing system has been documented from the geological record so far. The major implications for a

697 successful reconstruction of source-to-sink relationships and continental-scale paleogeographic

698 scenarios based on provenance studies of ancient sedimentary successions, which is of interest not 699 only in academic research but for the identification and quality assessment of hydrocarbon 700 reservoirs as well, remain to be investigated. 
701

702

703

704

705

706

707

708

709

710

711

712

713

714

715

716

717

718

719

720

721

722

723

724

725

726

727

\section{ACKNOWLEDGMENTS}

Field work was made possible by the logistic support of the University of Katyavala Bwila, Instituto Superior Politécnico da Tundavala, and by the kind help by Manuel Bandeira, Silvano Levy, Margarida Ventura, and Carlos Ribeiro, which we acknowledge warmly. We thank heartily Afonso Sampaio, Armanda Trindade, Edson Baptista, Alcides Pereira, Luciana Ciceri, Fernand Vermeesch, and Dany Kerckhove for collecting additional sand samples from the Cunene River and the Moçamedes Desert, and Claudia Pasquero and Elisa Malinverno for discussion. Laura Borromeo, Francesco Crotti, and Massimiliano Stucchi point-counted, grain-counted, and Raman-counted beach placers, and contributed to the analysis of Raman spectra of detrital garnets and Fe-Ti-Cr oxides. Danilo Controversio, Matteo Sala, and Ethan Petrou helped greatly in grain-density and geochronological analyses. Careful constructive reviews and useful advice kindly provided by Reviewers Michel Guiraud and Gareth Roberts, and by Editors Nick Lancaster and Nigel Mountney, were received gratefully.

\section{SUPPLEMENTARY MATERIAL}

Supplementary data associated with this article can be found in the online version, at http://dx.doi. . These include information on sampling sites (Table A1) and the complete datasets on bulk-sand petrography (Table A2), heavy minerals (Table A3), placer mineralogy including determination of opaque Fe-Ti-Cr oxides (Table A4), pyroxene grains (Table A5), and garnet grains (Table A6), grain-density (Table A7), bulk-sand geochemistry (Table A8), and zircon-geochronology (Appendix B). The Google-Earth map of sampling sites Mocamedes.kmz.is also provided. Table captions are contained in Appendix A, which illustrates the approach followed in the calculation of provenance budgets (A1) and of zircon and monazite concentration

based

on

chemical

data 
FIGURE CAPTIONS

730

731 Figure 1. Oceanography and sand transport along the west coast of southern Africa. A) The 1800

732 km-long Orange cell of littoral sand drift. Shelf width decreases north of Walvis Ridge and finally 733 tapers out to a few $\mathrm{km}$ north of Tombua (Fig. 4). Coastal dunefields: $\mathrm{N}=$ Namib; $\mathrm{S}=$ Skeleton 734 Coast; $\mathrm{C}=$ Cunene; $\mathrm{M}=$ Moçamedes. Yellow and green arrows indicate subordinate sediment 735 contribution from the Swakop and Cunene Rivers, respectively. Location of offshore samples is 736 indicated. B) Oceanographic features of the Benguela Current large marine ecosystem (after 737 Cochrane et al., 2009). Shelf topography is of particular significance for nearshore circulation and 738 fisheries. C) Net sediment transport around world coasts and paths of westerly swell generated in 739 the southern storm belt (after Silvester, 1962 and Davies, 1972). Dotted lines delimit major changes 740 in trends.

741

742 Figure 2. Beaches and beach placers in the terminal tract of the Orange littoral cell. Northern 743 Moçamedes Desert: A, B) foreshore and backshore sands enriched strongly in garnet and $\mathrm{Fe}-\mathrm{Ti}-\mathrm{Cr}$ 744 oxides at Vanesinha; C) prograding beach sand in the process of burying the Vanesa shipwreck 745 south of Tombua; white arrow indicates small erosion scarp at foreshore top. Subida Grande: (D) 746 foreshore laminae enriched strongly in Fe-Ti-Cr oxides and garnet in the background; E) small 747 backshore coppice dunes (nabkhah) enriched patchily in garnet and Fe-Ti-Cr oxides. Localities 748 indicated in Figures 4 and 5.

749

750 Figure 3. Beaches and beach placers north of Namibe. A) Beach in equilibrium at Baia das Salinas. 751 B) Foreshore laminae locally enriched strongly in Fe-Ti-Cr oxides at Bentiaba. C) Composite beach 752 at Inamangando (view looking southwest): $\mathbf{C}_{\mathbf{1}}$ ) high inner berm of white sand with the same 753 mineralogy as river sand (Figs. $7 \mathrm{E}_{1}$ ); $\mathbf{C}_{2}$ ) parallel laminae enriched strongly in Fe-Ti-Cr oxides 754 characterize erosion scarp at foreshore top $\left.\left(\mathbf{C}_{3}\right) ; \mathbf{C}_{4}\right)$ low outer berm of darker sand enriched notably 
755 in Fe-Ti-Cr oxides (Fig. 7 $\mathrm{E}_{2}$ ); $\mathbf{C}_{5}$ ) Google Earth image of the composite beach at the Inamangando

756 River mouth, showing lateral continuity in space and persistence in time of the white high inner

757 berm and heavy-mineral-enriched creamy orange low outer berm (boundary indicated by black

758 dotted line). Localities indicated in Figure 4.

759

760 Figure 4. Topography of the southern Angola continental margin, showing bathymetry and sample 761 locations. The shelf, still relatively wide offshore of the southern Moçamedes Desert, tapers off at 762 Tombua. The Curoca and Bero mouths are associated with a deep canyon reaching close to shore 763 (Fig. 15). A field of coppice dunes (Fig. 2E) occurs between Subida Grande and Namibe, but farther 764 north the shelfbreak comes even closer to the coast and dunefields disappear. $\mathrm{BdS}=$ Baia das 765 Salinas.

766

767 Figure 5. Google Earth images of selected sampling sites in the Moçamedes Desert. Changes in 768 dune color largely reflect different hydrodynamic concentration of ultradense garnet and $\mathrm{Fe}-\mathrm{Ti}-\mathrm{Cr}$ 769 oxides, which increases markedly and rather abruptly in the northern part of the desert (north of 770 white dotted line), where shelf width decreases rapidly offshore (Fig. 4). A) Small field of yellow 771 barchan dunes south of Tombua Bay, which is delimited by a sand spit. Wave refraction at the point 772 of coastal re-entrant fosters accumulation of drifting sand and incipient formation of a new spit at 773 Ponta do Enfião (fig. 8 in Guilcher et al., 1973); B) Deflation of ochre sand in the backshore of 774 Vanesa beach (note small linear dunes formed in the lee of shrubs; arrow points at shipwreck seen 775 in Fig. 2C); C) Deflation of dark red sand in the backshore of Vanesinha beach (Fig. 2A,B) with 776 composite red barchan dunes inland; D) Coalescent red barchan dunes at Praia do Navio; E) 777 Composite yellow transverse dunes at Baia dos Tigres, a toponym seemingly chosen by sailors 778 because concentration of red garnet and black Fe-Ti-Cr oxides makes beaches and dunes look like 779 tiger stripes from the sea; F) The Cunene River separates sharply the Cunene Erg in the south from 
780 a deflation area in the north. The direction of swell waves is constantly from the southwest. Blue 781 bar for scale $=500 \mathrm{~m}$.

782

783 Figure 6. Petrographic signatures in the Cunene River system. A) Pure quartzose recycled sand 784 supplied to the upper course $(q=$ quartz $)$. B) Quartzo-feldspathic plutoniclastic sand supplied to the 785 lower course $(\mathrm{p}=$ plagioclase; $\mathrm{c}=$ clinopyroxene $)$. C) Plagioclase-rich feldspatho-quartzose trunk786 river sand in the lower course upstream of the coastal Cunene dunefield. D) Litho-feldspatho787 quartzose metamorphiclastic sand supplied in the terminal tract $(\mathrm{a}=$ amphibole $)$. All photos with 788 crossed polars; blue bar for scale $=250 \mu \mathrm{m}$.

789

790 Figure 7. Changes in sand composition in southern Angola. A) River sand at Cunene mouth reveals 791 extensive mixing with dune sand fed from northward littoral drift $(\mathrm{q}=$ quartz; $\mathrm{a}=$ amphibole; $\mathrm{h}=$ 792 hypersthene). B) Beach sand at Cunene mouth is mainly derived ultralong-distance from the Orange 793 River. Orange-derived small rounded clinopyroxene (c) contrasts with Cunene-derived oversized 794 angular orthopyroxene (h). C) Small rounded clinopyroxene grains and basaltic rock fragments (B) 795 derived from as far as Lesotho highlands at the end of the Orange littoral cell. D) Feldspar-rich sand 796 with granitoid rock fragments $(\mathrm{G})$ derived from Angolan basement is supplied via the Bero River to 797 the Namibe beach. E) Feldspar-rich feldspatho-quartzose Inamangando River sand; E $\mathbf{1}_{\mathbf{1}}$ ) sand with 798 identical composition deposited on the high inner berm at the Inamangando mouth; $\mathbf{E}_{\mathbf{2}}$ ) marked 799 enrichment in opaque and transparent heavy-minerals in the low outer berm. All photos but $\mathbf{E}_{\mathbf{2}}$ with 800 crossed polars; blue bar for scale $=250 \mu \mathrm{m}$.

801

802 Figure 8. Sketch geological map showing major tectonic domains and river drainages in southern 803 Africa (compiled after Schlüter, 2008 and other sources cited in text).

804

805 Figure 9. Petrography and heavy minerals in sands of southern Angola. Composition of 806 Moçamedes Desert sand is close to Skeleton Coast sand with additional contribution from the 
807 Cunene River. Composition of Cunene sand changes progressively from the upper course largely 808 draining fossil Kalahari dunes to the lower course draining the Cunene igneous complex and Epupa 809 basement before cutting across the coastal dunefield. Very extensive mixing with coastal eolian 810 sand occurs in the final tract of the Curoca River. The Orange littoral cell terminates at Namibe, and 811 beach sand to the north is supplied by local rivers draining Angolan basement with minor recycling 812 of Cretaceous to Miocene strata exposed near the coast. $\mathrm{Q}=$ quartz; $\mathrm{F}=$ feldspar $(\mathrm{KF}=\mathrm{K}$-feldspar; $813 \mathrm{P}=$ plagioclase $) ; \mathrm{L}=$ lithic fragments $(\mathrm{Lm}=$ metamorphic; $\mathrm{Lv}=$ volcanic; $\mathrm{Ls}=$ sedimentary; $\mathrm{Lc}=$ 814 carbonate; $\mathrm{Lsm}=$ sedimentary + low-rank metasedimentary; Lvm $=$ volcanic + low-rank 815 metavolcanic; $\mathrm{Lm}^{*}=$ medium/high-rank metamorphic); HM = heavy minerals; ZTR $=$ zircon + 816 tourmaline + rutile. Both multivariate observations (points) and variables (rays) are displayed in the 817 compositional biplots (Gabriel, 1971). The length of each ray is proportional to the variance of the 818 corresponding element in the data set. If the angle between two rays is close to $0^{\circ}, 90^{\circ}$, or $180^{\circ}$, 819 then the corresponding elements are directly correlated, uncorrelated, or inversely correlated, 820 respectively.

Figure 10. Downstream changes in U-Pb age spectra of detrital zircons in sands of the Cunene

823 River (age vs. frequencies plotted as Kernel Density Estimates using the provenance package of 824 Vermeesch et al., 2016). Paleoproterozoic to Neoarchean zircons are most abundant in the mildly 825 sloped upper course draining fossil Kalahari dunes. Mid-Mesoproterozoic zircons become dominant 826 in the much steeper youthful lower course, where erosion is focused and the river is incising rapidly 827 into the Cunene igneous complex. Damara and Namaqua age peaks appear at the mouth, reflecting 828 extensive mixing with windblown sand mostly derived ultralong-distance from the Orange River. 829

830 Figure 11. U-Pb age spectra of detrital zircons in beach, dune and river sands from northern 831 Namibia to southern Angola. The northern termination of the Orange littoral cell at $15^{\circ} 12^{\prime} \mathrm{S}$ is 832 marked by the abrupt transition from bimodal spectra dominated by Damaran and Namaqua ages 
833 typical of Orange River and coastal Namibia sands to unimodal spectra dominated by Eburnean 834 ages, reflecting provenance of most zircon grains from Paleoproterozoic crystalline rocks of the 835 Angola Block (age vs. frequencies plotted as Kernel Density Estimates using software package 836 provenance; Vermeesch et al., 2016). Age spectra of detrital zircons carried by the Cunene and 837 Curoca Rivers at the mouth indicate that, rather than derived from their upstream reaches, they were 838 mainly supplied long-distance from the Orange River and blown from the coast to choke the river 839 valley inland. Nonetheless, significant zircon contribution from the Cunene River upstream of the 840 coastal erg is documented by mid-Mesoproterozoic and late Paleoproterozoic peaks, which are 841 notably larger in Moçamedes beaches and dunes than in Skeleton Coast dunes. Zircon contribution from the Curoca River upstream of the coastal erg is not evident.

Figure 12. Heavy minerals in recent sediments sampled from the Walvis Ridge to offshore of Baia dos Tigres. A) Offshore suites compare closely to either Skeleton Coast or Moçamedes Desert sands and differ drastically from those of all river sands from Namibia to Angola, documenting long-distance provenance mostly from the Orange mouth. B) Offshore suites tend to be depleted in ultradense minerals (garnet, opaque Fe-Ti-Cr oxides), preferentially retained in coastal sediments. $\mathrm{ZTR}=$ zircon + tourmaline + rutile; tHMC $=$ transparent heavy-mineral concentration. In the compositional biplot (Gabriel, 1971), the angle between two rays is close to $0^{\circ}, 90^{\circ}$, or $180^{\circ}$ if the 852

Figure 13. Intersample mineralogical variability of beach and dune sands is controlled by both sizedensity sorting during selective entrainment $\left(1^{\text {st }}\right.$ principal component $)$ and provenance $\left(2^{\text {nd }}\right.$ principal component). Low-density quartz, feldspars and rock fragments all correlate more and more

856 negatively with denser and denser minerals. Moçamedes sand is richer in garnet, staurolite and 857 pyroxenes, rivers and beaches north of Namibe in epidote and amphibole. HMC $=$ Heavy Mineral Concentration. In the compositional biplot (Gabriel, 1971), the angle between two rays is close to 
$8590^{\circ}, 90^{\circ}$, or $180^{\circ}$ if the corresponding variables are directly correlated, uncorrelated, or inversely

860 correlated, respectively.

861

862 Figure 14. Different patterns of intersample chemical variability in coastal sands of southern 863 Angola (elements arranged following the periodic table group by group). In beach placers formed 864 by selective-entrainment processes, $\mathrm{Na}, \mathrm{K}, \mathrm{Rb}, \mathrm{Ba}$, and $\mathrm{Si}$ hosted in low-density tectosilicates are 865 depleted progressively, whereas Y, REE, Th, U, Ti, Zr, Hf, V, Nb, Ta, Cr, Mn, Fe, Co, and P hosted 866 in dense and ultradense minerals are enriched, and the Eu anomaly is strongly negative. A) 867 Moçamedes and Skeleton Coast sands have similar composition, indicating common long-distance 868 provenance mainly from the Orange River. Moçamedes placers show the same pattern as Coastal 869 Namib placers, with progressive increase in Sc, Y, HREE, and Mn reflecting garnet enrichment 870 (concentrations normalized to averaged analyses of 19 Coastal Namib beach and dune sands after 871 Garzanti et al., 2015b). B) Beach placers and semi-placers north of the Orange cell are enriched in 872 LREE and especially Th, indicating monazite concentration, scarcity of garnet, and local 873 provenance from Angolan basement rocks (concentrations normalized to averaged analyses of 8 874 beach and river sands collected between Namibe and Lucira). Chondrite-normalized REE patterns 875 are controlled principally by the concentration of garnet in Coastal Namib and Moçamedes placer 876 sands (C) and by concentration of monazite in placer sand derived from Angolan basement (D). 877 REE patterns of heavy minerals after Garzanti et al. (2011).

879 Figure 15. The Orange littoral sand highway terminates abruptly just east of Praia Amelia, where 880 garnet placers occur (Torquato, 1970). Sand dragged by swell waves from the south feeds the 881 subaqueous spit in front of Praia Amelia, but it is funnelled next in the submarine canyon connected 882 to the Bero mouth. The beach in Namibe Bay is supplied by the Bero River. 
884

885

886

887

888

889

890

891

892

893

894

895

896

897

898

899

900

901

902

903

904

905

906

907

908

909

910

911

REFERENCES

Al-Hajri, Y., White, N. and Fishwick, S. (2009) Scales of transient convective support beneath Africa. Geology, 37, 883-887.

Alberti, A., Piccirillo, E.M., Bellieni, G., Civetta, L., Comin-Chiaramonti, P. and Morais, E.A.A. (1992) Mesozoic acid volcanics from southern Angola: petrology, Sr-Nd isotope characteristics and correlation with acid stratoid volcanic suites of the Paranà basin (southeastern Brazil). European Journal of Mineralogy, 4, 597-604.

Allison, M.A. and Lee, M.T. (2004) Sediment exchange between Amazon mudbanks and shore-fringing mangroves in French Guiana. Marine Geology, 208, 169-190.

Andò, S., Vignola, P. and Garzanti, E. (2011) Raman counting: a new method to determine provenance of silt Rendiconti Lincei Scienze Fisiche e Naturali, 22, 327-347.

Andò, S. and Garzanti, E. (2014) Raman spectroscopy in heavy-mineral studies. Geological Society London, Special Publications, 386, 395-412.

Becker, T., Schreiber, U., Kampunzu, A.B. and Armstrong, R. (2006) Mesoproterozoic rocks of Namibia and their plate tectonic setting. Journal of African Earth Sciences, 46, 112-140.

Besler, H. (1996) The Tsondab Sandstone in Namibia and its significance for the Namib erg. South African Journal of Geology, 99, 77-87.

Bluck, B.J.,Ward, J.D.,Cartwright, J. and Swart, R. (2007) The Orange River, southern Africa: an extreme example of a wave-dominated sediment dispersal system in the South Atlantic Ocean. Journal of the Geological Society, London 164, 341-351.

Boyd, R., Ruming, K., Goodwin, I., Sandstrom, M. and Schröder-Adams, C. (2008) Highstand transport of coastal sand to the deep ocean: a case study from Fraser Island, southeast Australia. Geology, 36, 1518.

Bremner, J.M. and Willis J.P. (1993) Mineralogy and geochemistry of the clay fraction of sediments from the Namibian continental margin and the adjacent hinterland. Marine Geology, 115, 85-116.

Bremner, J.M., Rogers, J. and Willis, J.P. (1990) Sedimentological aspects of the 1988 Orange River floods. Transactions of the Royal Society of South Africa, 47, 247-294. 
912 Bullard, J.E., White, K. and Livingstone, I. (2011) Morphometric analysis of aeolian bedforms in the 913 Namib Sand Sea using ASTER data. Earth Surface Processes and Landforms, 36, 1534-1549.

914 Calliari, L.J. and Toldo, E.E. (2016) Ocean beaches of Rio Grande do Sul. In: Short, A.D. and Klein, 915 A.H.D.F. (Eds.), Brazilian Beach Systems. Springer, Switzerland, Coastal Research Library, 17, pp. $916 \quad 507-541$

917 Carvajal, C., Steel, R. and Petter, A. (2009) Sediment supply: the main driver of shelf-margin growth. 918 Earth-Science Reviews, 96, 221-248.

919 Cascalho, J. and Fradique, C. (2007) The sources and hydraulic sorting of heavy minerals on the northern 920 Portuguese continental margin. In: Mange, M.A. and Wright, D.T. (Eds.), Heavy minerals in use. 921 Elsevier, Amsterdam, Developments in Sedimentology Series, 58, pp. 75-110.

Cochrane, K.L., Augustyn, C.J., Fairweather, T., Japp, D., Kilongo, K., Iitembu, J., Moroff, N., Roux, 923 Ecosystem-Governance and management for an ecosystem approach to fisheries in the region. Coastal Management, 37, 235-254.

Compton, J.S. and Wiltshire, J.G. (2009) Terrigenous sediment export from the western margin of South Africa on glacial to interglacial cycles. Marine Geology, 266, 212-222.

Corbett, I. (1993) The modern and ancient pattern of sandflow through the southern Namib deflation basin. International Association of Sedimentology, Special Publication 16, 45-60.1993

Courrech du Pont, S., Narteau, C. and Gao, X. (2014) Two modes for dune orientation. Geology, 42, 743746.

Covault, J.A. and Fildani, A. (2014) Continental shelves as sediment capacitors or conveyors: source-to933 sink insights from the tectonically active Oceanside shelf, southern California, USA. In: Chiocci, F.L. and Chivas, A.R. (Eds), Continental shelves of the world: their evolution during the last glacio-eustatic cycle. Geological Society London, Memoir 41, 315-326.

Cox, K.G. (1989) The role of mantle plumes in the development of continental drainage patterns. Nature, 342, 873-877.

Davies, J.L. (1972) Geographical variation in coastal development. Oliver and Boyd, Edinburgh, 204 p.

939 De Carvalho, H., Tassinari, C., Alves, P.H., Guimarães, F. and Simões, M.C. (2000) Geochronological 940 review of the Precambrian in western Angola: links with Brazil. Journal of African Earth Sciences, 31, 941 383-402. 
942 Dickinson, W.R. (1988) Provenance and sediment dispersal in relation to paleotectonics and 943 paleogeography of sedimentary basins. In: Kleinspehn, K.L. and Paola, C. (Eds.), New perspectives in 944 basin analysis. New York, Springer, pp. 3-25.

945 Dillenburg, S.R., Tomazelli, L.J., Barboza, E.G. (2004) Barrier evolution and placer formation at Bujuru 946 southern Brazil. Marine Geology, 203, 43-56.

947 Dinis, P.A. and Soares, A.F. (2007) Stable and ultrastable heavy minerals of alluvial to nearshore marine 948 sediments from Central Portugal: facies related trends. Sedimentary Geology, 201, 1-20.

949 Dinis, P., Huvi, J., Cascalho, J., Garzanti, E., Vermeesch, P. and Callapez, P. (2016) Sand-spits systems 950 from Benguela region (SW Angola). An analysis of sediment sources and dispersal from textural and 951 compositional data. Journal of African Earth Sciences, 117, 171-182.

952 dos Santos, V.F., Short, A.D. and Mendes, A.C. (2016) Beaches of the Amazon Coast: Amapá and West 953 Pará. In: Short, A.D. and Klein, A.H.D.F. (Eds.), Brazilian Beach Systems. Springer, Switzerland, $954 \quad$ Coastal Research Library, 17, pp. 67-93.

955 Gabriel, K.R. (1971) The biplot graphic display of matrices with application to principal component 956 analysis. Biometrika, 58, 453-467.

957 Galehouse, J.S. (1971) Point counting. In: Carver, R.E. (Ed.), Procedures in Sedimentary Petrology. Wiley, $958 \quad$ New York, pp. 385-407.

959 Gao, X., Narteau, C. and Rozier, O. (2015) Development and steady states of transverse dunes: a numerical 960 analysis of dune pattern coarsening and giant dunes. Journal of Geophysical Research: Earth Surface, $961 \quad 120,2200-2219$.

962 Garzanti, E. (2016) From static to dynamic provenance analysis - Sedimentary petrology upgraded. $963 \quad$ Sedimentary Geology, 336, 3-13.

964 Garzanti, E. and Andò, S. (2007) Heavy-mineral concentration in modern sands: implications for 965 provenance interpretation. In: Mange, M.A. and Wright, D.T. (Eds.), Heavy minerals in use. Elsevier, 966 Amsterdam, Developments in Sedimentology Series, 58, pp. 517-545.

967 Garzanti, E. and Vezzoli, G. (2003) A classification of metamorphic grains in sands based on their 968 composition and grade. Journal of Sedimentary Research, 73, 830-837.

969 Garzanti, E., Andò, S. and Vezzoli, G. (2009) Grain-size dependence of sediment composition and 970 environmental bias in provenance studies. Earth and Planetary Science Letters, 277, 422-432. 
971

972

973

974

975

976

977

978

979

980

981

982

983

984

985

986

987

988

989

990

991

992

993

994

995

996

997

998

999

Garzanti, E., Andò, S., France-Lanord, C., Galy, V., Censi, P. and Vignola, P. (2011) Mineralogical and chemical variability of fluvial sediments. 2. Suspended-load silt (Ganga-Brahmaputra, Bangladesh). Earth and Planetary Science Letters, 302, 107-120.

Garzanti, E., Andò, S., Vezzoli, G., Lustrino, M., Boni, M. and Vermeesch, P. (2012a) Petrology of the Namib sand sea: long-distance transport and compositional variability in the wind-displaced Orange Delta. Earth-Science Reviews, 11, 173-189.

Garzanti, E., Resentini, A., Vezzoli, G., Andò, S., Malusà, M. and Padoan, M. (2012b) Forward compositional modelling of Alpine orogenic sediments. Sedimentary Geology, 280, 149-164.

Garzanti, E., Vermeesch, P., Andò, S., Lustrino, M., Padoan, M. and Vezzoli, G. (2014) Ultra-long distance littoral transport of Orange sand and provenance of the Skeleton Coast Erg (Namibia). Marine Geology, 357, 25-36.

Garzanti, E., Andó, S., Padoan, M., Vezzoli, G. and El Kammar, A. (2015a) The modern Nile sediment system: processes and products. Quaternary Science Reviews, 130, 9-56.

Garzanti, E., Resentini, A., Andò, S., Vezzoli, G. and Vermeesch, P. (2015b) Physical controls on sand composition and relative durability of detrital minerals during long-distance littoral and eolian transport (coastal Namibia). Sedimentology, 62, 971-996.

Garzanti, E., Dinis, P., Vermeesch, P., Andò, S., Hahn, A., Huvi, J., Limonta, M., Padoan, M., Resentini, A., Rittner, M. and Vezzoli, G. (2017) Dynamic uplift, recycling and weathering control on the petrology of subequatorial passive-margin sands (Angola). Sedimentary Geology, in review.

Gindre-Chanu, L., Perri E., Sharp, I.R., Peacock, D.C.P., Swart, R., Poulsen R., Ferreira, H. and Machado, V. (2016) Origin and diagenetic evolution of gypsum and microbialitic carbonates in the Late Sag of the Namibe Basin (SW Angola). Sedimentary Geology, 342, 133-153

Goudie, A. and Viles, H. (2015) The North East Kunene Region: The Kunene River, Sand Sea and Yardangs. In: Landscapes and Landforms of Namibia. Springer Netherlands, pp. 55-59.

Gray, D.R., Foster, D.A., Meert, J.G., Goscombe, B.D., Armstrong, R., Trouw, R.A.J. and Passchier, C.W. (2008) A Damara Orogen perspective on the assembly of southwestern Gondwana. In: Pankhurst, R.J., Trouw, R.A.J., Brito Neves, B.B. and De Wit, M.J. (Eds.), West Gondwana: pre-Cenozoic correlations across the South Atlantic region. Geological Society of London, Special Publication 294, 257-278. 
1000 Griffin, W.L., Powell, W.J., Pearson, N.J. and O'Reilly, S.Y. (2008) GLITTER: data reduction software 1001 for laser ablation ICP-MS. Laser Ablation-ICP-MS in the earth sciences. Mineralogical association of 1002 Canada short course series, 40, 204-207

1003 Guilcher, A. (2010) Angola. In: Bird, E.C.F. (Ed.), Encyclopedia of the world's coastal landforms. Springer, 1004 Dordrecht, The Netherlands, pp. 963-967.

1005 Guilcher, A., Medeiros, C.A., Matos, J.E. and Oliveira, J.T. (1974) Les restingas (fléches littorales) 1006 d'Angola, spécialment celles du sud et du centre. Finisterra, 9, 117-211.

1007 Guiraud, M., Buta-Neto, A. and Quesne, D. (2010) Segmentation and differential post-rift uplift at the 1008 Angola margin as recorded by the transform-rifted Benguela and oblique-to-orthogonal-rifted Kwanza 1009 basins. Marine and Petroleum Geology, 27, 1040-1068.

1010 Haddon, I.G. and McCarthy, T.S. (2005) The Mesozoic-Cenozoic interior sag basins of Central Africa: the 1011 1012 1013

Hardman-Mountford, N.J., Richardson, A.J., Agenbag, J.J., Hagen, E., Nykjaer, L., Shillington, F.A. 1014 1015 1016 1017 Late-Cretaceous-Cenozoic Kalahari and Okavango basins. Journal of African Earth Sciences, 43, 316333.

and Villacastin, C. (2003) Ocean climate of the South East Atlantic observed from satellite data and wind models. Prog. Oceanogr., 59, 181-221.

Hay, W.W. (1998) Detrital sediment fluxes from continents to oceans. Chemical Geology, 145, 287-323.

Ingersoll, R.V., Bullard, T.F., Ford, R.L., Grimm, J.P., Pickle, J.D. and Sares, S.W. (1984) The effect of grain size on detrital modes: a test of the Gazzi-Dickinson point-counting method. Journal of Sedimentary Petrology, 54, 103-116.

Ingersoll, R.V., Dickinson, W.R. and Graham, S.A. (2003) Remnant-ocean submarine fans: largest sedimentary systems on Earth. In: Chan, M.A. and Archer, A.W. (Eds.), Extreme depositional environments: mega end members in geologic time. Geological Society of America, Special Paper 370, pp. 191-208.

Inman, D.L. and Jenkins, S.A. (1984) The Nile littoral cell and man's impact on the coastal zone of the 1025 southeastern Mediterranean. Scripps Institution of Oceanography, Reference Series, 31, 1-43.

1026 Inman, D.L. and Jenkins, S.A. (2005) Accretion and erosion waves on beaches. In: Encyclopedia of Coastal 1027 Science, Schwartz, M., (Ed.), Kluwer, Dordrecht, The Netherlands, 11 p. 
Jacobson, P.J., Jacobson, K.M. and Seely, M.K. (1995) Ephemeral rivers and their catchments: sustaining people and development in western Namibia. Desert Research Foundation of Namibia, Windhoek, 160 pp.

Kaminsky, G.M., Ruggiero, P., Buijsman, M.C., McCandless, D. and Gelfenbaum, G. (2010) Historical evolution of the Columbia River littoral cell. Marine Geology, 273, 96-126.

Kirst, G.J., Schneider, R.R., Muller, P.J., von Storch, I. and Wefer, G. (1999) Late Quaternary Temperature Variability in the Benguela Current System derived from alkenones. Quaternary Research, $52,92-103$.

Kocurek, G., Lancaster, N., Carr, M. and Frank, A. (1999) Tertiary Tsondab Sandstone Formation: preliminary bedform reconstruction and comparison to modern Namib sand sea dunes. Journal of African Earth Sciences, 29, 629-642.

Komar, P.D. (1977) Selective longshore transport rates of different grain-size fractions within a beach. Journal of Sedimentary Research, 47, 1444-1453.

Komar, P.D. (2007) The entrainment, transport and sorting of heavy minerals by waves and currents In: Mange, M.A. and Wright, D.T. (Eds.), Heavy minerals in use. Elsevier, Amsterdam, Developments in Sedimentology Series, 58, pp. 3-48.

Kudrass, H.R. (1987) Sedimentary models to estimate the heavy-mineral potential of shelf sediments. In: Teleki, P.G., Dobson, M.R., Moore, J.R. and von Stackelberg, U. (Eds.), Marine minerals: advances in research and resource assessment. Springer, The Netherlands, pp. 39-56.

Kudrass, H.R. (2000) Marine placer deposits and sea-level changes. In: Cronan, D.S. (Ed.), Handbook of marine mineral deposits. CRC Press, Boca Raton, Florida, pp. 3-26.

Jury, M. (2010) Climate and weather factors modulating river flows in southern Angola. International Journal of Climatology, 30, 901-908.

Lancaster, N. (1982) Dunes on the Skeleton Coast, Namibia (South West Africa): geomorphology and grain size relationships. Earth Surface Processes and Landforms, 7, 575-587.

Lancaster, N. (2014) Dune systems of the Namib Desert - a spatial and temporal perspective. Transactions of the Royal Society of South Africa, 69, 133-137.

Lass, H.U., Schmidt, M., Mohrholz, V. and Nausch, G. (2000) Hydrographic and current measurements in the area of the Angola-Benguela Front. Journal of Physical Oceanography, 30, 2589-2609. 
1057

1058

1059

1060

1061

1062

1063

1064

1065

1066

1067

1068

1069

1070

1071

1072

1073

1074

1075

1076

1077

1078

1079

1080

1081

1082

1083

1084

1085

1086

Manhique, A.J., Reason, C.J.C., Silinto, B., Zucula, J., Raiva, I., Congolo, F. and Mavume, A.F. (2015) Extreme rainfall and floods in southern Africa in January 2013 and associated circulation patterns. Natural Hazards, 77, 679-691.

Meeuwis, J.M. and Lutjeharms, J.R.E. (1990) Surface thermal characteristics of the Angola-Benguela front. South African Journal of Marine Science, 9, 261-279.

Milliman. J.D. and Farnsworth, K.L. (2011) River discharge to the coastal ocean. A global synthesis. Cambridge University Press, New York, 384 p.

Patsch, K. and Griggs, G. (2007) Development of sand budgets for California's major littoral cells. Institute of Marine Sciences, University of California, Santa Cruz, 115 p.

Peel, M.C., Finlayson, B.L. and McMahon, T.A. (2007) Updated world map of the Koppen-Geiger climate classification. Hydro. Earth Syst. Sci., 11, 1633-1644.

Potter, P.E. (1978) Significance and origin of big rivers. The Journal of Geology, 86, 13-33.

Quesne, D., Buta-Neto, A., Benard, D. and Guiraud, M. (2009) Distribuition of Albian clastic deposits in the Benguela basin (Angola): evidence of a Benguela paleocorrent? Bulletin de la Société Géologique de France, 180, 117-129.

Reffet, E., Courrech du Pont, S., Hersen, P. and Douady, S. (2010) Formation and stability of transverse and longitudinal sand dunes. Geology, 38, 491-494.

Rogers, J. (1977) Sedimentation on the continental margin off the Orange River and the Namib desert. Geology Survey/University of Cape Town Marine Geosciences Group Bulletin, 7, 1-162.

Rogers, J. and Bremner, J.M. (1991) The Benguela ecosystem. VII: Marine-geological aspects. In: Barnes, M. (Ed.), Oceanography and marine biology. Aberdeen University Press, Oceanography and Marine Biology - An Annual Review, 29, 1-85.

Rogers, J. and Rau, A.J. (2006) Superficial sediments of the wave-dominated Orange River delta and the adjacent continental margin off southwestern Africa. African Journal of Marine Sciences, 28, 511-524.

Rooseboom, A. and Harmse, H.J. von M. (1979) Changes in sediment load of the Orange River during the period 1929-1969. Hydrology of Areas of Low Precipitation, International Association of Hydrological Sciences Publication 128, pp. 459-479.

Rouault, M., Illig, S., Bartholomae, C., Reason, C.J.C. and Bentamy, A. (2007) Propagation and origin of warm anomalies in the Angola Benguela upwelling system in 2001. Journal of Marine Systems, 68, $473-488$ 
1087 Roy, P.S. (1999) Heavy mineral beach placers in southeastern Australia; their nature and genesis. Economic Geology, 94, 567-588.

1089 Ruggiero, P., Kaminsky, G.M., Gelfenbaum, G. and Voigt, B. (2005) Seasonal to interannual 1090 morphodynamics along a high-energy dissipative littoral cell. Journal of Coastal Research, 21, 553-578.

1091

1092

1093

1094

1095

1096

1097

1098

1099

1100

1101

1102

1103

1104

1105

1106

1107

1108

1109

1110

1111

1112

1113

1114

1115

Schoonees, J.S. (2000) Annual variation in the net longshore sediment transport rate. Coastal Engineering, $40,141-160$.

Schlüter, T. (2008) Geological Atlas of Africa. Springer, Heidelberg, 307 p.

Schulz, H.D., Beese, D., Breitzke, M., Brück, L., Brügger, B., Dahmke, A., Dehning, K., Diekamp, V., Dünner, B., Ehrhardt, I., Gerlach, H., Giese, M., Glud, R., Gumprecht, R., Gundersen, J., Henning, R., Hinrichs, S., Petermann, H., Richter, M., Sagemann, J., Schmidt, W., Schneider, R., Scholz, M., Segl, M., Werner, U. and Zabel, M. (1992) Bericht und erste Ergebnisse über die MeteorFahrt M20/2, Abidjan-Dakar, 27.12.1991-3.2.1992. Berichte aus dem Fachbereich Geowissenschaften der Universität Bremen, 025. Department of Geosciences, Bremen University.

Scott, R.A., Smyth, H.R., Morton, A.C. and Richardson, N. (2014) Sediment Provenance Studies in Hydrocarbon Exploration and Production. Geological Society London, Special Publications, 386, 420 p.

Shannon, L.V. and Nelson, G. (1996) The Benguela: large scale features and processes and system variability. In: Wefer, W.H.B.G., Siedler, G. and Webb, D. (Eds.), The South Atlantic: present and past circulation. Springer, Berlin, pp. 163-210.

Shannon, L.V., Boyd, A.J., Brundrit, G.B. and Taunton-Clark, J. (1986) On the existence of an El Niñotype phenomenon in the Benguela system. Journal of Marine Research, 44, 495-520.

Shaw, A. and Goudie, A.S. (2002) Geomorphological evidence for the extension of the Mega-Kalahari into south-central Angola. South African Geographical Journal, 84, 182-194.

Silvester, R. (1962) Sediment movement around the coastlines of the world. Proceedings of the Institution of Civil Engineers, Paper 14, 289-315.

Silvester, R. (1984) Fluctuations in littoral drift. American Society of Civil Engineers, Proceedings of the $19^{\text {th }}$ Conference on Coastal Engineering, Houston, Texas, chapter 88, 1291-1305.

Silvester, R. and Mogridge, G.R. (1970) Reach of waves to the bed of the continental shelf. American Society of Civil Engineers, Proceedings of $12^{\text {th }}$ Conference on Coastal Engineering, Washington, D.C., chapter 40, 651-667. 
1116 Spaggiari, R.I., Bluck, B.J. and Ward, J.D. (2006) Characteristics of diamondiferous Plio-Pleistocene 1117 littoral deposits within the palaeo-Orange River mouth, Namibia. Ore Geology Reviews, 28, 475-492.

1118 Strganac, C., Salminen, J., Jacobs, L.L., Polcyn, M.J., Ferguson, K.M., Mateus, O., Schulp, A.S., 1119 Morais, M.L., Tavares; T. da S. and Gonçalves, A.O. (2014) Carbon isotope stratigraphy, 1120 magnetostratigraphy, and 40Ar/39Ar age of the Cretaceous South Atlantic coast, Namibe Basin, 1121

Torquato, J.R. (1970) Origin and evolution of the Moçamedes desert (Angola). Boletim do Instituo de Angola. Journal of African Earth Sciences, 99, 452-462.

1124 Ward, J.D. (1988) Eolian, fluvial and pan (playa) facies of the Tertiary Tsondab Sandstone Formation in the 1125 central Namib desert, Namibia. Sedimentary Geology, 55, 143-162.

Vermeesch, P., Fenton, C.R., Kober, F., Wiggs, G.F.S., Bristow, C.S. and Xu, S. (2010) Sand residence 1127 times of one million years in the Namib Sand Sea from cosmogenic nuclides. Nature Geosciences, 3, $862-865$

Vermeesch, P., Resentini, A. and Garzanti, E. (2016) An R package for statistical provenance analysis. Sedimentary Geology, 336, 14-25.

1131

1132

Vermeesch, P., Rittner, M. and Garzanti, E. (2017) QEMSCAN+LA-ICP-MS: a 'big data' generator for sedimentary provenance analysis. Geophysical Research Abstracts, EGU General Assembly, 19, EGU2017-17171-1.

Wefer, G., Bleil, U., Müller, P.J., Schulz, H.D., Berger, W.H., Brathauer, U., Brück, L., Dahmke, A., Dehning, K., Durate-Morais, M.L., Fürsich, F., Hinrichs, S., Klockgeter, K., Kölling, A., Kothe, C., Makaya, J.F., Oberhänsli, H., Oschmann, W., Posny, J., Rostek, F., Schmidt, H., Schneider, R.R., Segl, M., Sobiesiak, M., Soltwedel, T. and Spieß, V. (1988) Bericht über die Meteor-Fahrt M66, Libreville - Las Palmas, 18.2.1988 - 23.3.1988. Berichte aus dem Fachbereich Geowissenschaften der Universität Bremen, 003. Department of Geosciences, Bremen University.

Wefer, G., Berger, W.H., Richter, C. and Shipboard Scientific Party (1998) Proceedings of the Ocean Drilling Program, Initial Reports, Vol. 175, 8. Site 1080, 201-221.

Zuffa, G.G., Normark, W.R., Serra, F. and Brunner, C.A. (2000) Turbidite megabeds in an oceanic rift valley recording Jökulhlaups of Late Pleistocene glacial lakes of the western United States. The Journal of Geology, 108, 253-274. 

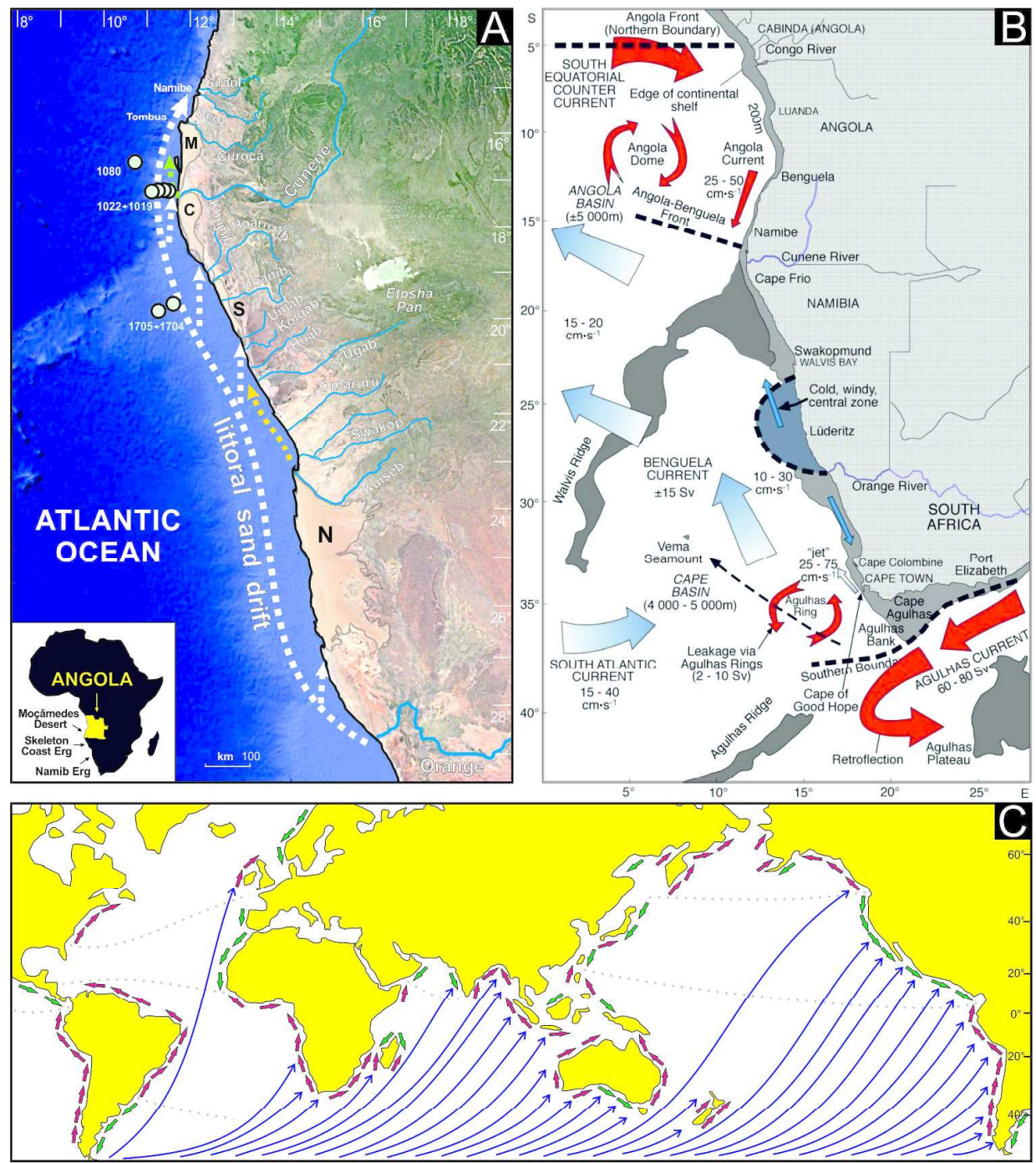

Figure 1 Moçamedes

Figure 1. Oceanography and sand transport along the west coast of southern Africa. A) The $1800 \mathrm{~km}$-long Orange cell of littoral sand drift. Shelf width decreases north of Walvis Ridge and finally tapers out to a few

km north of Tombua (Fig. 4). Coastal dunefields: $\mathrm{N}=$ Namib; $\mathrm{S}=$ Skeleton Coast; $\mathrm{C}=$ Cunene; $\mathrm{M}=$

Moçamedes. Yellow and green arrows indicate subordinate sediment contribution from the Swakop and Cunene Rivers, respectively. Location of offshore samples is indicated. B) Oceanographic features of the Benguela Current large marine ecosystem (after Cochrane et al., 2009). Shelf topography is of particular significance for nearshore circulation and fisheries. C) Net sediment transport around world coasts and paths of westerly swell generated in the southern storm belt (after Silvester, 1962 and Davies, 1972). Dotted lines delimit major changes in trends.

Fig. 1

$236 \times 269 \mathrm{~mm}(300 \times 300$ DPI $)$ 

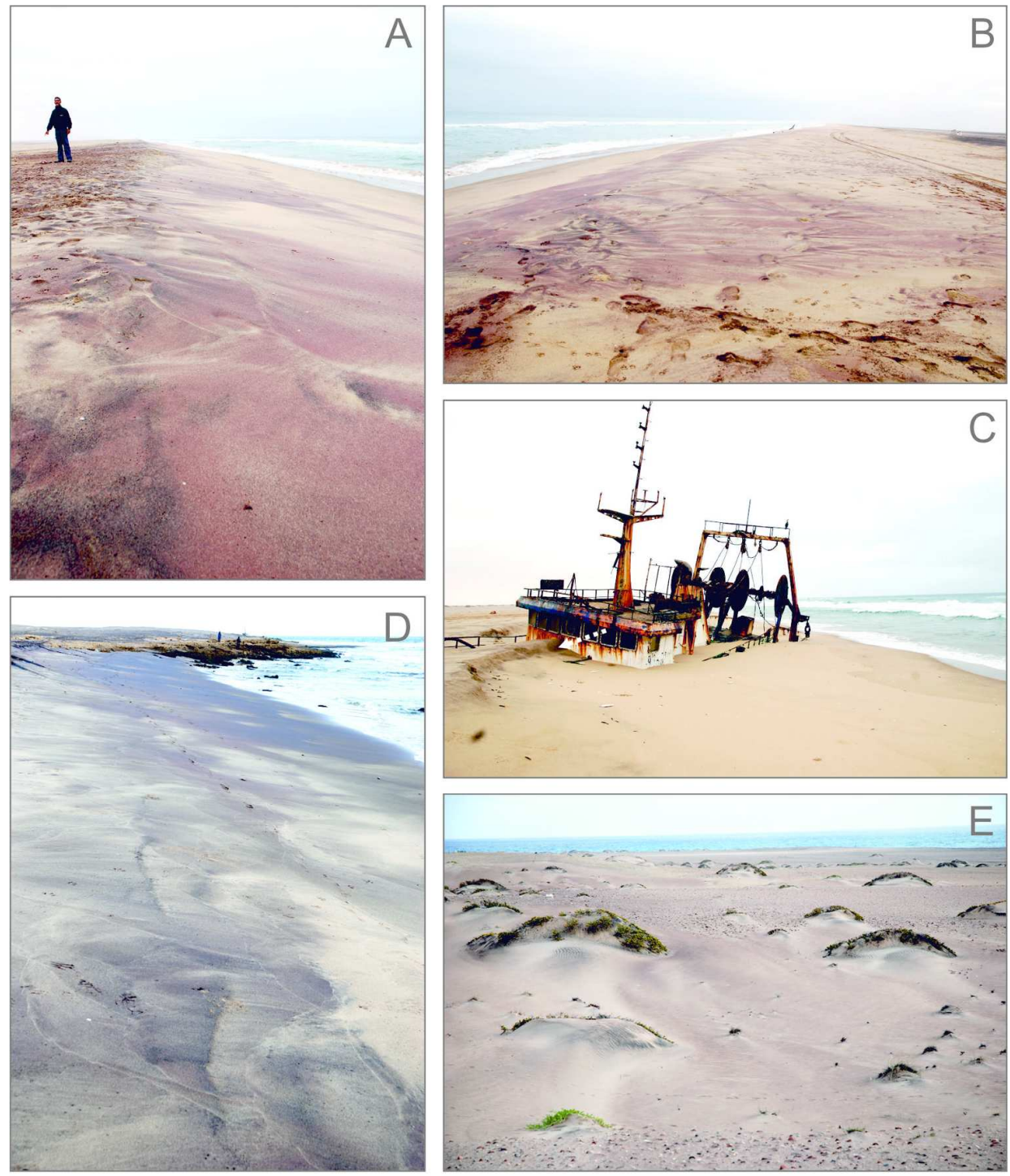

\section{Figure 2 Moçamedes}

Figure 2. Beaches and beach placers in the terminal tract of the Orange littoral cell. Northern Moçamedes Desert: A, B) foreshore and backshore sands enriched strongly in garnet and $\mathrm{Fe}-\mathrm{Ti}-\mathrm{Cr}$ oxides at Vanesinha; C) prograding beach sand in the process of burying the Vanesa shipwreck south of Tombua; white arrow indicates small erosion scarp at foreshore top. Subida Grande: (D) foreshore laminae enriched strongly in

$\mathrm{Fe}-\mathrm{Ti}-\mathrm{Cr}$ oxides and garnet in the background; E) small backshore coppice dunes (nabkhah) enriched patchily in garnet and Fe-Ti-Cr oxides. Localities indicated in Figures 4 and 5.

Fig. 2

$159 \times 197 \mathrm{~mm}(300 \times 300$ DPI $)$ 

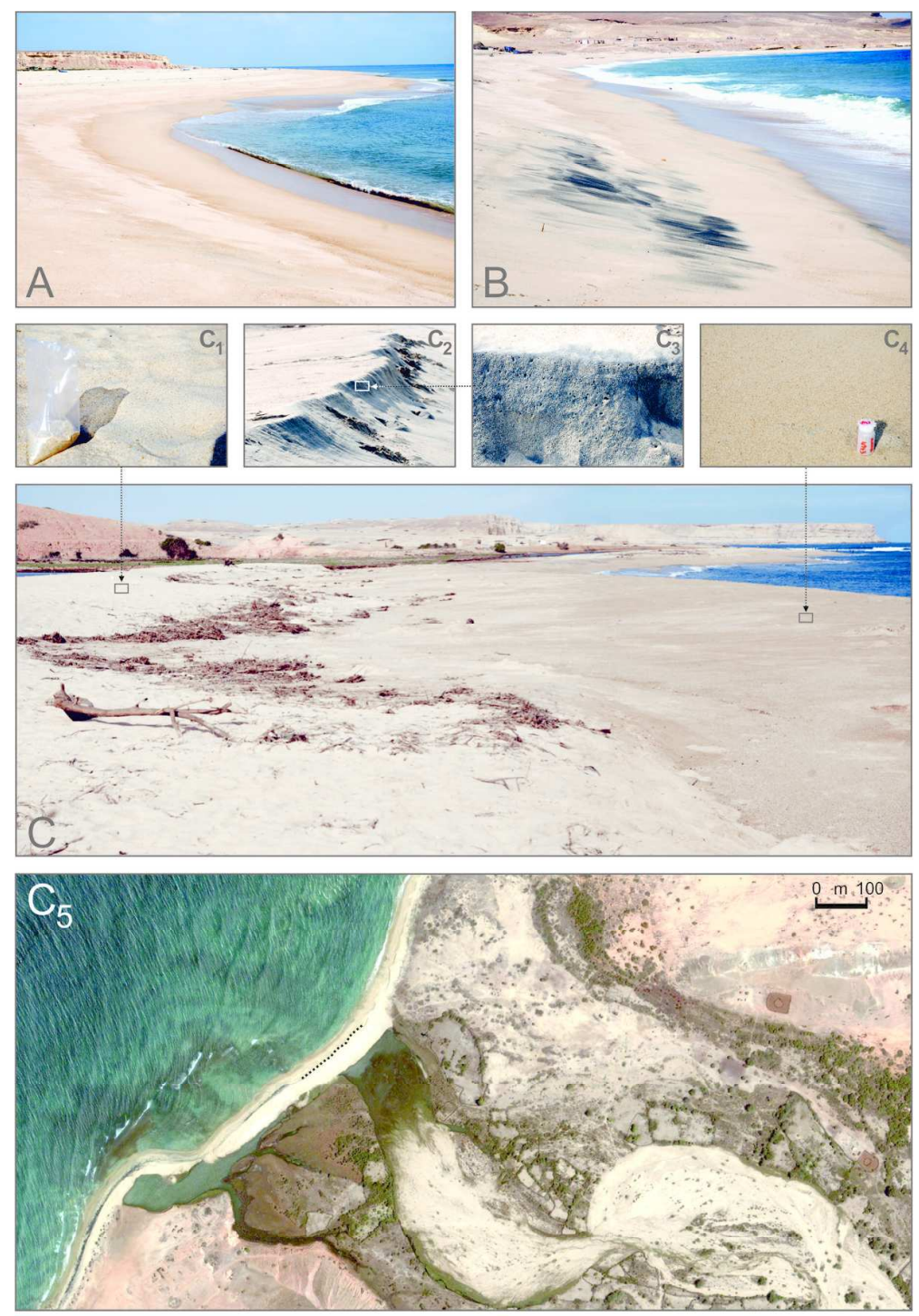

\section{Figure 3 Moçamedes}

Figure 3. Beaches and beach placers north of Namibe. A) Beach in equilibrium at Baia das Salinas. B) Foreshore laminae locally enriched strongly in Fe-Ti-Cr oxides at Bentiaba. C) Composite beach at Inamangando (view looking southwest): C1) high inner berm of white sand with the same mineralogy as river sand (Figs. 7E1); C2) parallel laminae enriched strongly in $\mathrm{Fe}-\mathrm{Ti}-\mathrm{Cr}$ oxides characterize erosion scarp at foreshore top (C3); C4) low outer berm of darker sand enriched notably in Fe-Ti-Cr oxides (Fig. 7E2); C5) Google Earth image of the composite beach at the Inamangando River mouth, showing lateral continuity in space and persistence in time of the white high inner berm and heavy-mineral-enriched creamy orange low outer berm (boundary indicated by black dotted line). Localities indicated in Figure 4.

$$
\text { Fig. } 3
$$




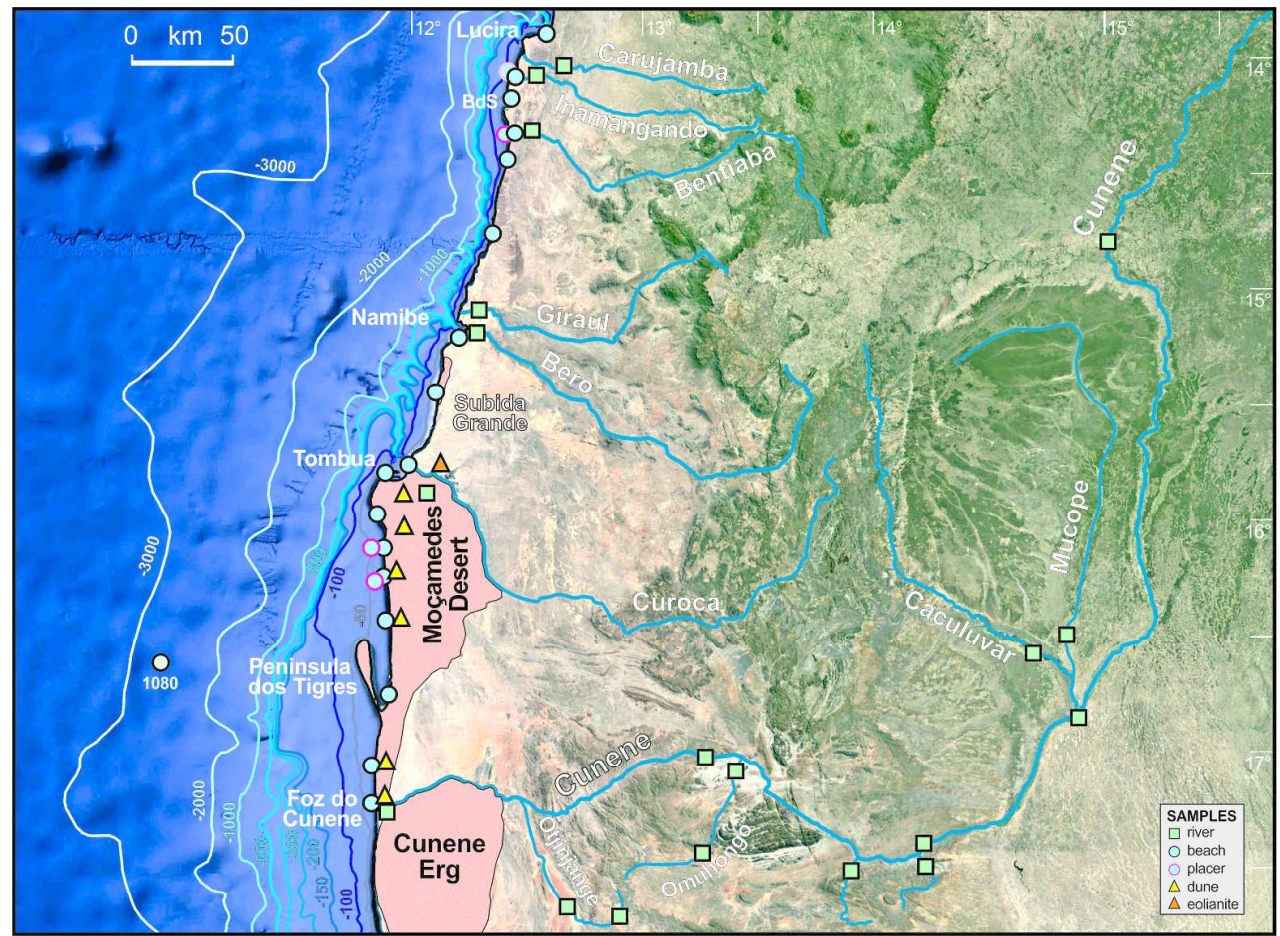

Figure 4 Moçamedes

Figure 4. Topography of the southern Angola continental margin, showing bathymetry and sample locations. The shelf, still relatively wide offshore of the southern Moçamedes Desert, tapers off at Tombua. The Curoca and Bero mouths are associated with a deep canyon reaching close to shore (Fig. 15). A field of coppice dunes (Fig. 2E) occurs between Subida Grande and Namibe, but farther north the shelfbreak comes even closer to the coast and dunefields disappear. BdS= Baia das Salinas.

Fig. 4 

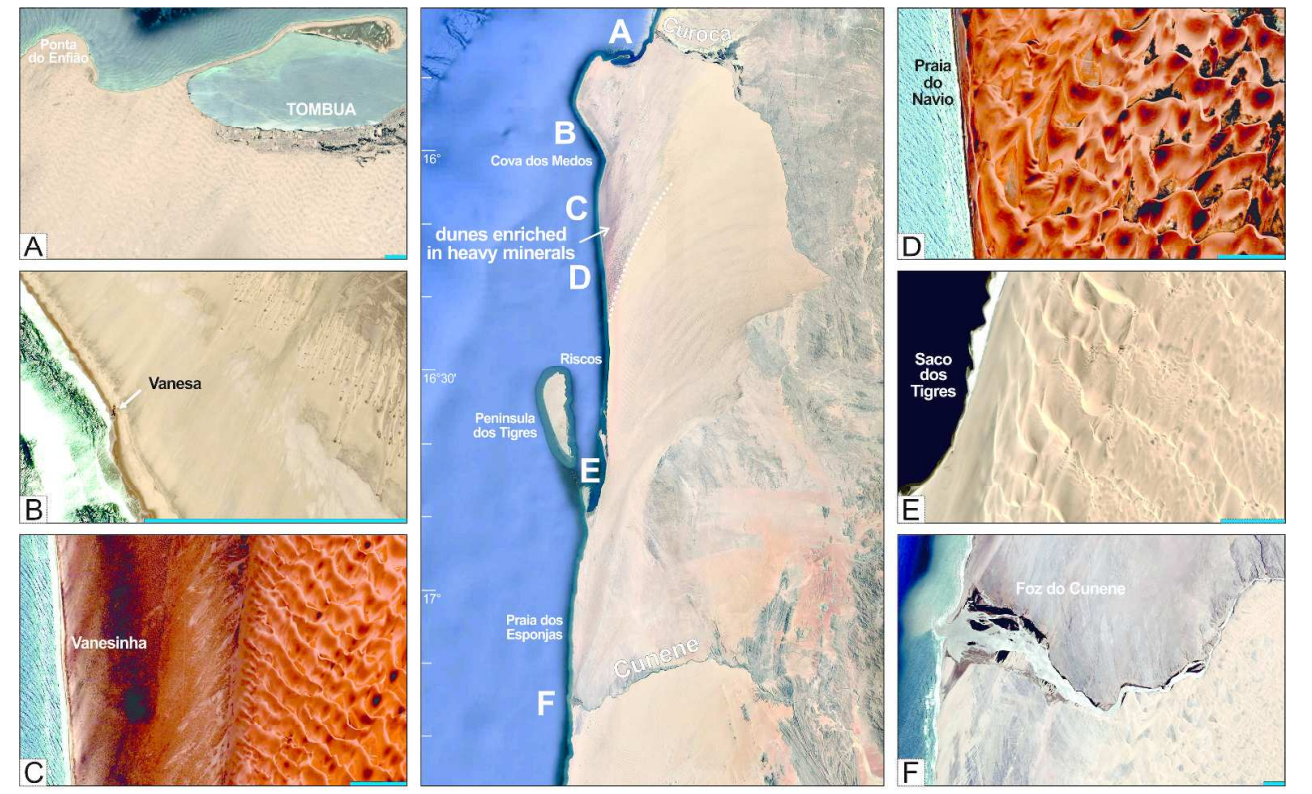

Figure 5 Moçamedes

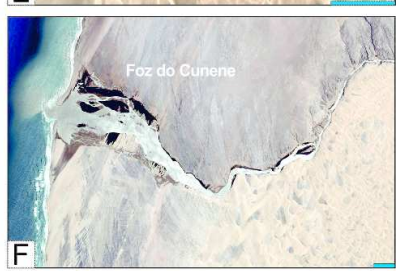

Figure 5. Google Earth images of selected sampling sites in the Moçamedes Desert. Changes in dune color largely reflect different hydrodynamic concentration of ultradense garnet and $\mathrm{Fe}-\mathrm{Ti}-\mathrm{Cr}$ oxides, which increases markedly and rather abruptly in the northern part of the desert (north of white dotted line), where shelf width decreases rapidly offshore (Fig. 4). A) Small field of yellow barchan dunes south of Tombua Bay, which is delimited by a sand spit. Wave refraction at the point of coastal re-entrant fosters accumulation of drifting sand and incipient formation of a new spit at Ponta do Enfião (fig. 8 in Guilcher et al., 1973); B)

Deflation of ochre sand in the backshore of Vanesa beach (note small linear dunes formed in the lee of shrubs; arrow points at shipwreck seen in Fig. 2C); C) Deflation of dark red sand in the backshore of Vanesinha beach (Fig. 2A,B) with composite red barchan dunes inland; D) Coalescent red barchan dunes at Praia do Navio; E) Composite yellow transverse dunes at Baia dos Tigres, a toponym seemingly chosen by sailors because concentration of red garnet and black Fe-Ti-Cr oxides makes beaches and dunes look like tiger stripes from the sea; F) The Cunene River separates sharply the Cunene Erg in the south from a deflation area in the north. The direction of swell waves is constantly from the southwest. Blue bar for scale

$=500 \mathrm{~m}$.
Fig. 5 


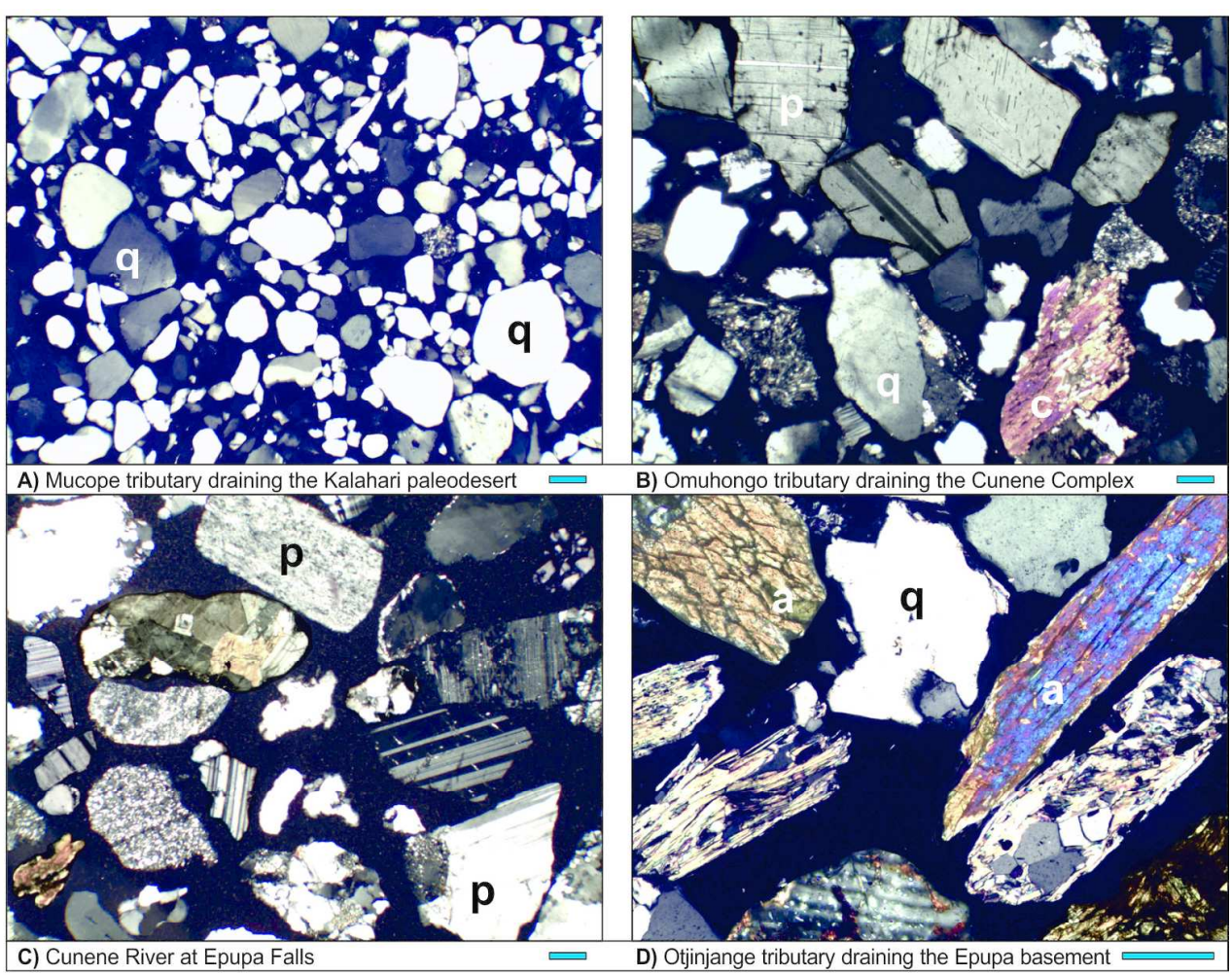

Figure 6 Moçamedes

Figure 6. Petrographic signatures in the Cunene River system. A) Pure quartzose recycled sand supplied to the upper course $(q=$ quartz). B) Quartzo-feldspathic plutoniclastic sand supplied to the lower course $(p=$ plagioclase; $c=$ clinopyroxene). C) Plagioclase-rich feldspatho-quartzose trunk-river sand in the lower course upstream of the coastal Cunene dunefield. D) Litho-feldspatho-quartzose metamorphiclastic sand supplied in the terminal tract $(a=$ amphibole). All photos with crossed polars; blue bar for scale $=250 \mu \mathrm{m}$. Fig. 6

$186 \times 157 \mathrm{~mm}(300 \times 300 \mathrm{DPI})$ 


\section{1}

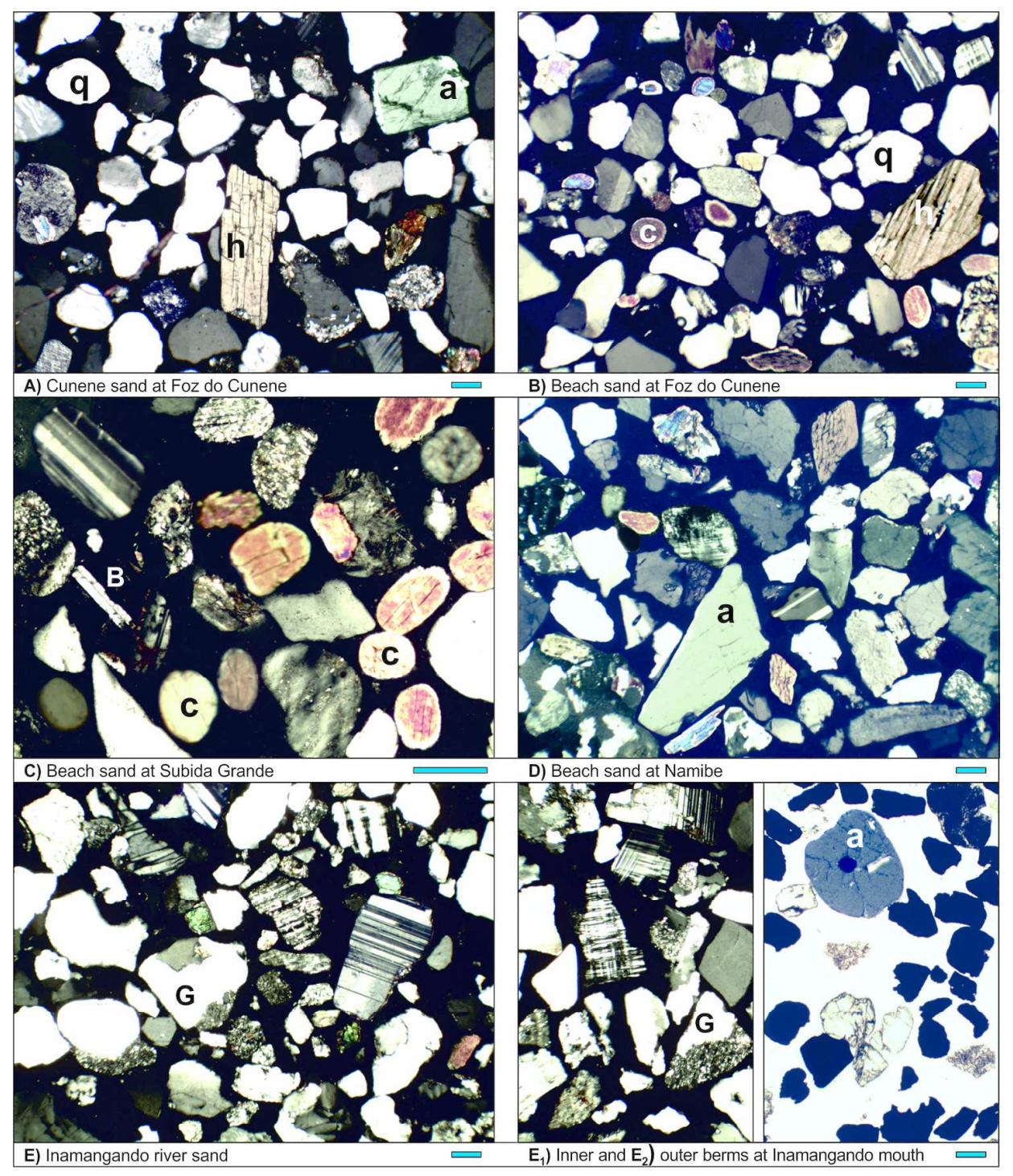

\section{Figure 7 Moçamedes}

Figure 7. Changes in sand composition in southern Angola. A) River sand at Cunene mouth reveals extensive mixing with dune sand fed from northward littoral drift ( $\mathrm{q}=$ quartz; $\mathrm{a}=$ amphibole; $\mathrm{h}=\mathrm{hypersthene}$ ). $\mathrm{B}$ ) Beach sand at Cunene mouth is mainly derived ultralong-distance from the Orange River. Orange-derived small rounded clinopyroxene (c) contrasts with Cunene-derived oversized angular orthopyroxene (h). C)

Small rounded clinopyroxene grains and basaltic rock fragments (B) derived from as far as Lesotho highlands at the end of the Orange littoral cell. D) Feldspar-rich sand with granitoid rock fragments (G) derived from Angolan basement is supplied via the Bero River to the Namibe beach. E) Feldspar-rich feldspatho-quartzose Inamangando River sand; E1) sand with identical composition deposited on the high inner berm at the Inamangando mouth; E2) marked enrichment in opaque and transparent heavy-minerals in the low outer berm. All photos but E2 with crossed polars; blue bar for scale $=250 \mu \mathrm{m}$.

Fig. 7 


\section{Page 55 of 81}

\section{Sedimentology}

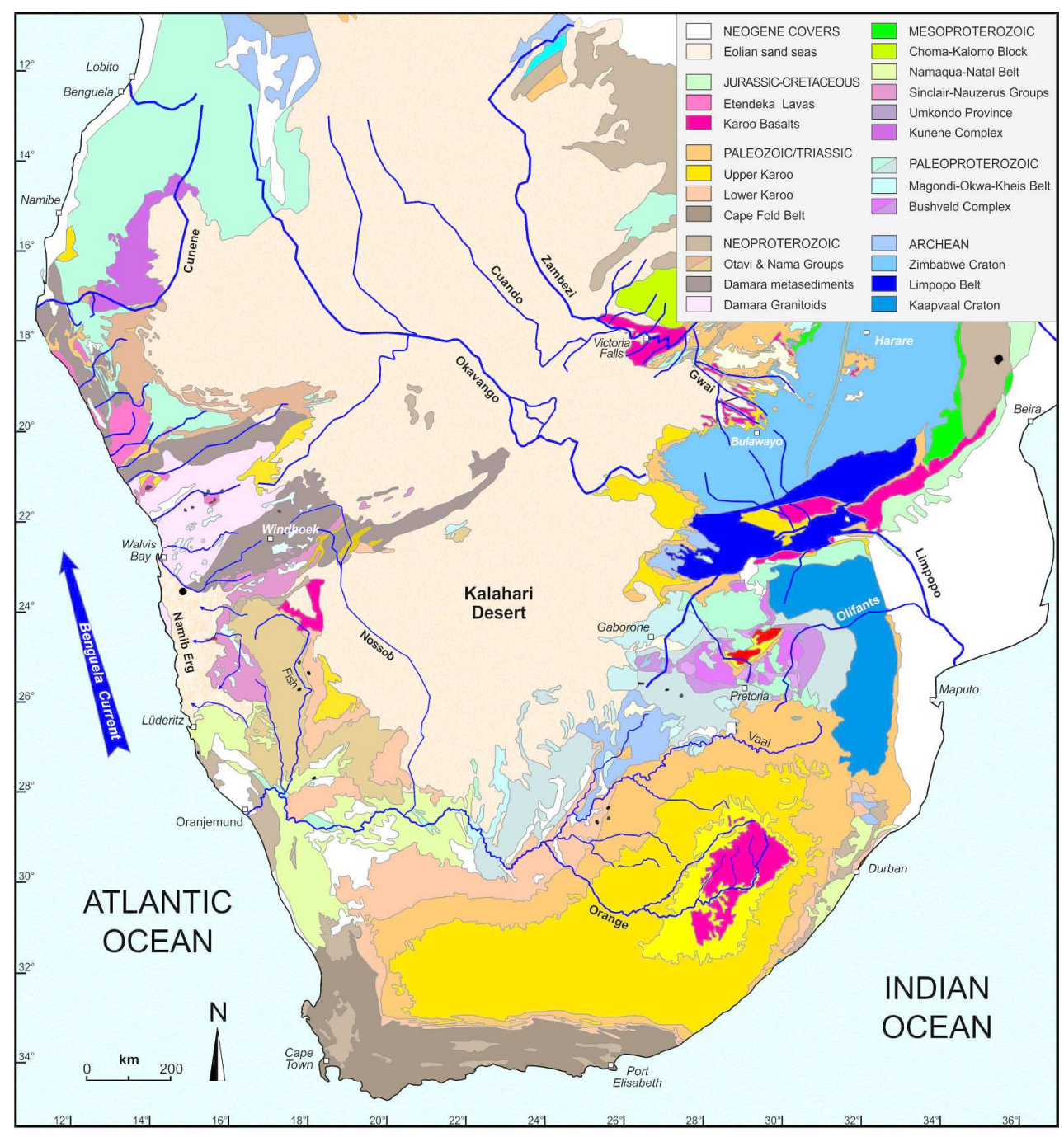

Figure 8 Moçamedes

Figure 8. Sketch geological map showing major tectonic domains and river drainages in southern Africa (compiled after Schlüter, 2008 and other sources cited in text).

Fig. 8

$211 \times 238 \mathrm{~mm}(300 \times 300$ DPI $)$ 


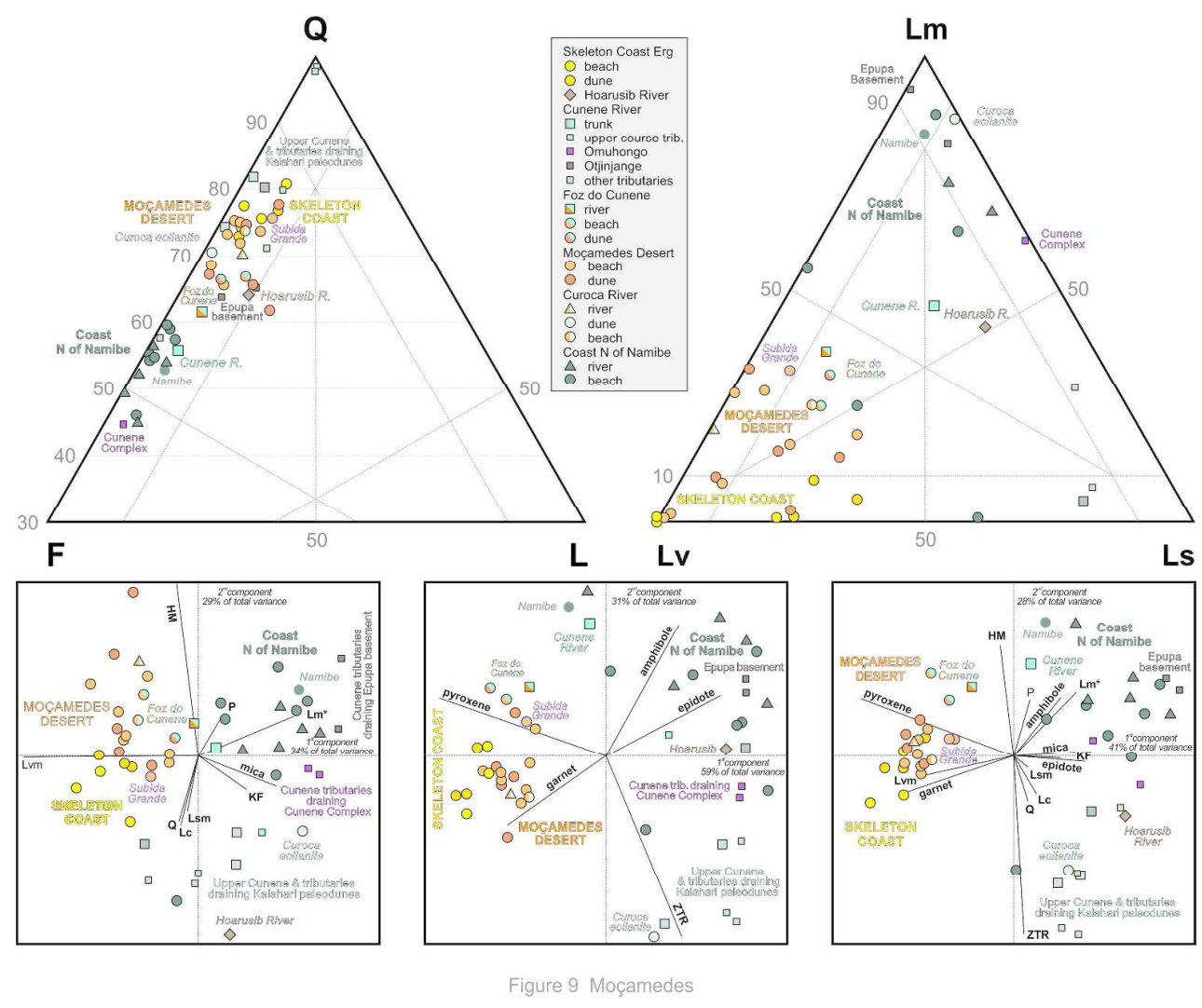

Figure 9. Petrography and heavy minerals in sands of southern Angola. Composition of Moçamedes Desert sand is close to Skeleton Coast sand with additional contribution from the Cunene River. Composition of Cunene sand changes progressively from the upper course largely draining fossil Kalahari dunes to the lower course draining the Cunene igneous complex and Epupa basement before cutting across the coastal dunefield. Very extensive mixing with coastal eolian sand occurs in the final tract of the Curoca River. The Orange littoral cell terminates at Namibe, and beach sand to the north is supplied by local rivers draining Angolan basement with minor recycling of Cretaceous to Miocene strata exposed near the coast. Q = quartz; $\mathrm{F}=$ feldspar $(\mathrm{KF}=\mathrm{K}$-feldspar; $\mathrm{P}=$ plagioclase $) ; \mathrm{L}=$ lithic fragments $(\mathrm{Lm}=$ metamorphic; $\mathrm{Lv}=$ volcanic; $\mathrm{Ls}$ = sedimentary $; \mathrm{LC}=$ carbonate; $\mathrm{Lsm}=$ sedimentary + low-rank metasedimentary; Lvm = volcanic + lowrank metavolcanic; Lm* = medium/high-rank metamorphic); HM = heavy minerals; ZTR = zircon + tourmaline + rutile. Both multivariate observations (points) and variables (rays) are displayed in the compositional biplots (Gabriel, 1971). The length of each ray is proportional to the variance of the corresponding element in the data set. If the angle between two rays is close to $0^{\circ}, 90^{\circ}$, or $180^{\circ}$, then the corresponding elements are directly correlated, uncorrelated, or inversely correlated, respectively. Fig. 9 


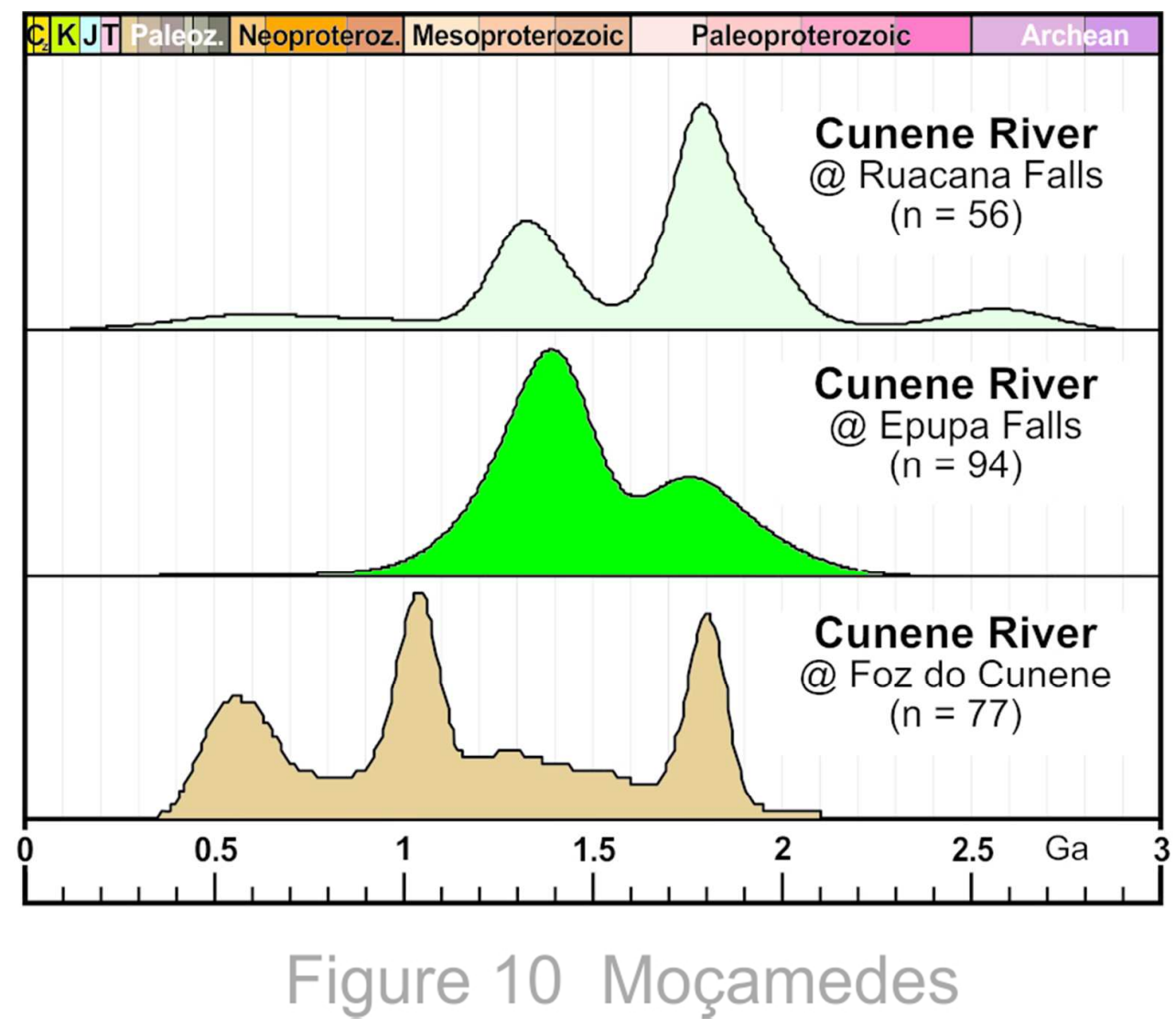

Figure 10. Downstream changes in U-Pb age spectra of detrital zircons in sands of the Cunene River (age vs. frequencies plotted as Kernel Density Estimates using the provenance package of Vermeesch et al., 2016). Paleoproterozoic to Neoarchean zircons are most abundant in the mildly sloped upper course draining fossil Kalahari dunes. Mid-Mesoproterozoic zircons become dominant in the much steeper youthful lower course, where erosion is focused and the river is incising rapidly into the Cunene igneous complex. Damara and Namaqua age peaks appear at the mouth, reflecting extensive mixing with windblown sand mostly derived ultralong-distance from the Orange River.

Fig. 10

$74 \times 64 \mathrm{~mm}(300 \times 300$ DPI $)$ 


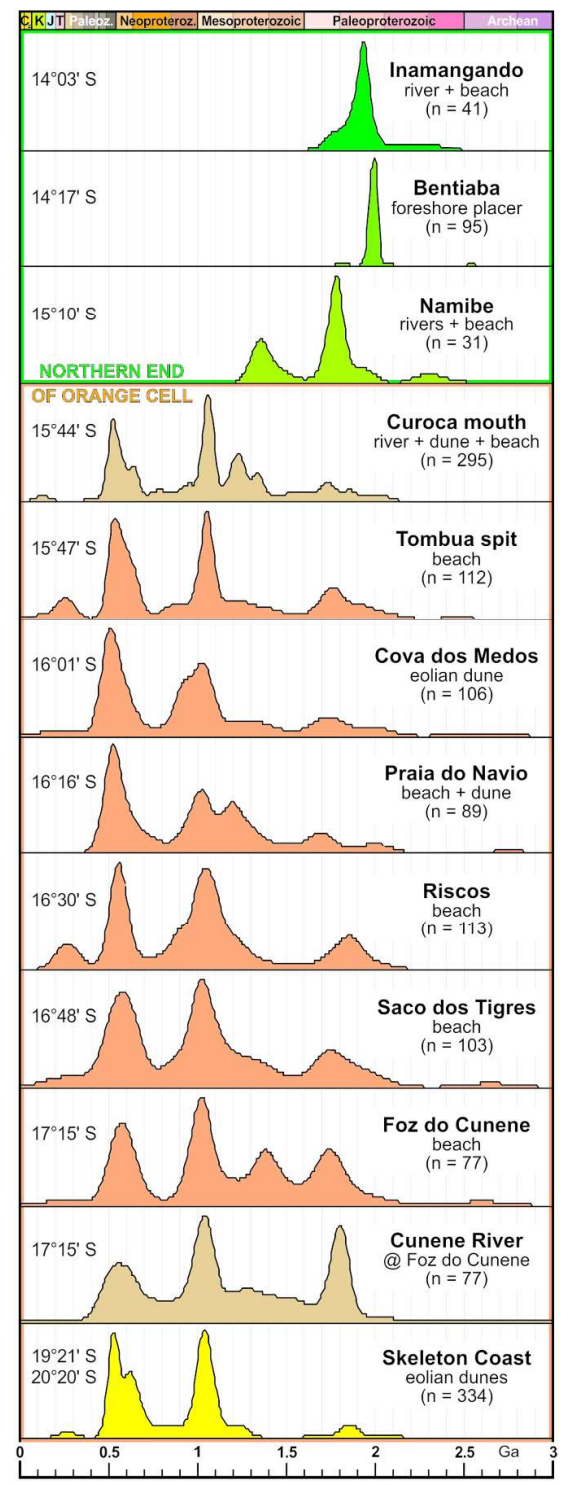

Figure 11 Moçamedes

Figure 11. U-Pb age spectra of detrital zircons in beach, dune and river sands from northern Namibia to southern Angola. The northern termination of the Orange littoral cell at $15^{\circ} 12^{\prime} \mathrm{S}$ is marked by the abrupt transition from bimodal spectra dominated by Damaran and Namaqua ages typical of Orange River and coastal Namibia sands to unimodal spectra dominated by Eburnean ages, reflecting provenance of most zircon grains from Paleoproterozoic crystalline rocks of the Angola Block (age vs. frequencies plotted as Kernel Density Estimates using software package provenance; Vermeesch et al., 2016). Age spectra of detrital zircons carried by the Cunene and Curoca Rivers at the mouth indicate that, rather than derived from their upstream reaches, they were mainly supplied long-distance from the Orange River and blown from the coast to choke the river valley inland. Nonetheless, significant zircon contribution from the Cunene River upstream of the coastal erg is documented by mid-Mesoproterozoic and late Paleoproterozoic peaks, which are notably larger in Moçamedes beaches and dunes than in Skeleton Coast dunes. Zircon contribution from the Curoca River upstream of the coastal erg is not evident. 


\section{Page 59 of 81}

1

2

3

4

5

6

9

10

11

12

13

14

15

16

17

18

19

20

21

22

23

24

26

27

29

30

31

32

34

35

36

37

38

39

40

41

42

43

44

45

46

47

48

49

50

51

52

53

55

56

57

58

59

60
Sedimentology

$74 \times 208 \mathrm{~mm}(300 \times 300$ DPI $)$ 


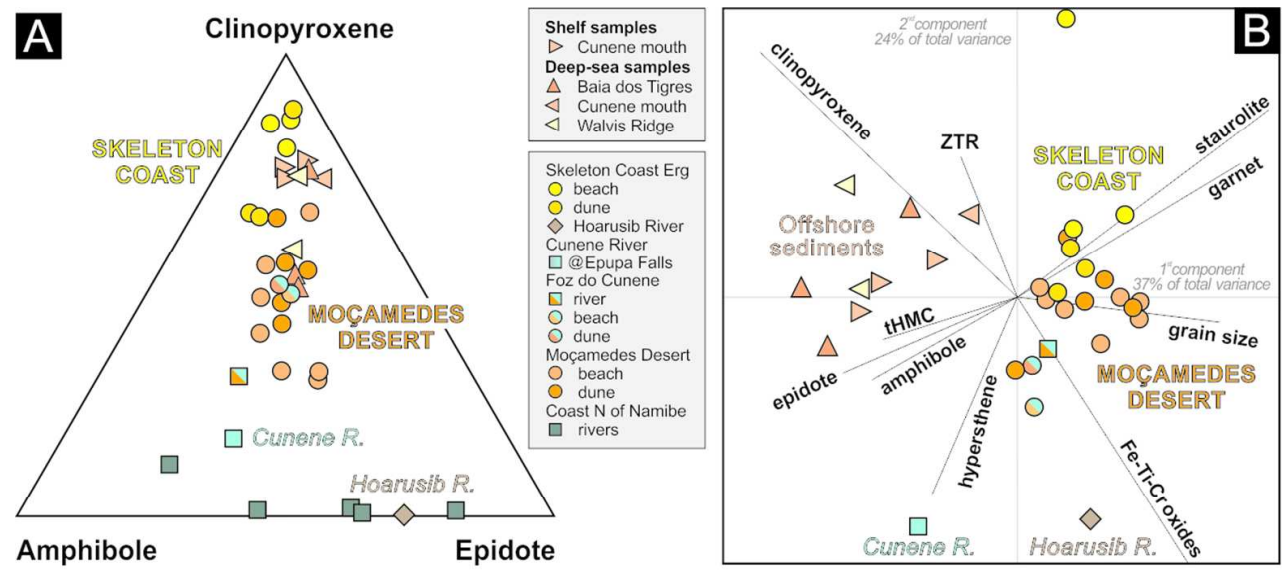

Figure 12 Moçamedes

Figure 12. Heavy minerals in recent sediments sampled from the Walvis Ridge to offshore of Baia dos Tigres. A) Offshore suites compare closely to either Skeleton Coast or Moçamedes Desert sands and differ drastically from those of all river sands from Namibia to Angola, documenting long-distance provenance mostly from the Orange mouth. B) Offshore suites tend to be depleted in ultradense minerals (garnet, opaque $\mathrm{Fe}-\mathrm{Ti}-\mathrm{Cr}$ oxides), preferentially retained in coastal sediments. ZTR = zircon + tourmaline + rutile; tHMC = transparent heavy-mineral concentration. In the compositional biplot (Gabriel, 1971), the angle between two rays is close to $0^{\circ}, 90^{\circ}$, or $180^{\circ}$ if the corresponding variables are directly correlated, uncorrelated, or inversely correlated, respectively.

Fig. 12

$114 \times 55 \mathrm{~mm}(300 \times 300$ DPI $)$ 


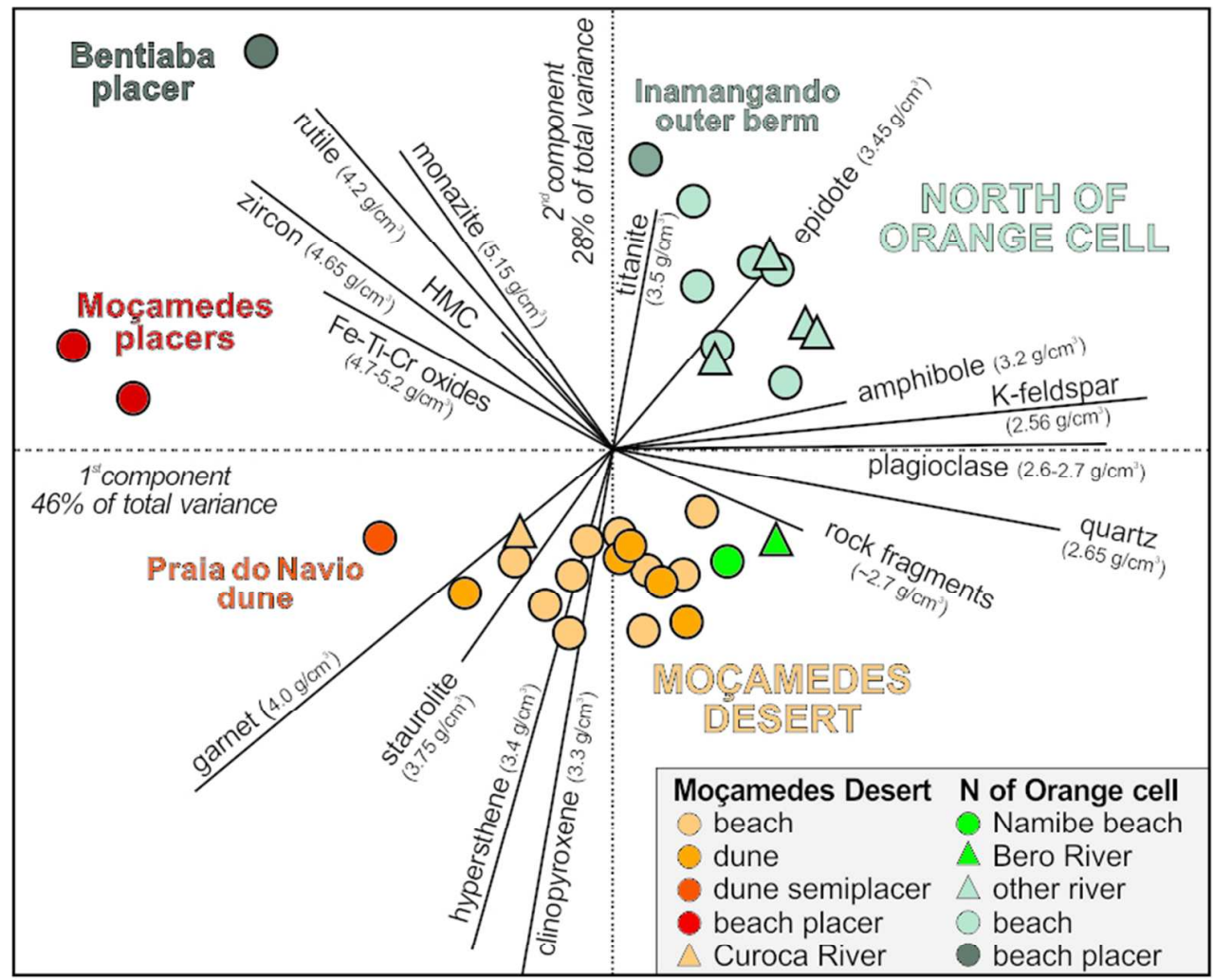

\section{Figure 13 Moçamedes}

Figure 13. Intersample mineralogical variability of beach and dune sands is controlled by both size-density sorting during selective entrainment (1st principal component) and provenance (2nd principal component). Low-density quartz, feldspars and rock fragments all correlate more and more negatively with denser and denser minerals. Moçamedes sand is richer in garnet, staurolite and pyroxenes, rivers and beaches north of Namibe in epidote and amphibole. HMC = Heavy Mineral Concentration. In the compositional biplot (Gabriel, 1971), the angle between two rays is close to $0^{\circ}, 90^{\circ}$, or $180^{\circ}$ if the corresponding variables are directly correlated, uncorrelated, or inversely correlated, respectively.

Fig. 13

$75 \times 66 \mathrm{~mm}(300 \times 300 \mathrm{DPI})$ 



Figure 14. Different patterns of intersample chemical variability in coastal sands of southern Angola (elements arranged following the periodic table group by group). In beach placers formed by selectiveentrainment processes, $\mathrm{Na}, \mathrm{K}, \mathrm{Rb}, \mathrm{Ba}$, and $\mathrm{Si}$ hosted in low-density tectosilicates are depleted progressively, whereas $\mathrm{Y}, \mathrm{REE}, \mathrm{Th}, \mathrm{U}, \mathrm{Ti}, \mathrm{Zr}, \mathrm{Hf}, \mathrm{V}, \mathrm{Nb}, \mathrm{Ta}, \mathrm{Cr}, \mathrm{Mn}, \mathrm{Fe}, \mathrm{Co}$, and $\mathrm{P}$ hosted in dense and ultradense minerals are enriched, and the Eu anomaly is strongly negative. A) Moçamedes and Skeleton Coast sands have similar composition, indicating common long-distance provenance mainly from the Orange River. Moçamedes placers show the same pattern as Coastal Namib placers, with progressive increase in Sc, Y, HREE, and Mn reflecting garnet enrichment (concentrations normalized to averaged analyses of 19 Coastal Namib beach and dune sands after Garzanti et al., 2015b). B) Beach placers and semi-placers north of the Orange cell are enriched in LREE and especially Th, indicating monazite concentration, scarcity of garnet, and local provenance from Angolan basement rocks (concentrations normalized to averaged analyses of 8 beach and river sands collected between Namibe and Lucira). Chondrite-normalized REE patterns are controlled principally by the concentration of garnet in Coastal Namib and Moçamedes placer sands (C) and by concentration of monazite in placer sand derived from Angolan basement (D). REE patterns of heavy minerals after Garzanti et al. (2011).

Fig. 14 $239 \times 217 \mathrm{~mm}(300 \times 300 \mathrm{DPI})$ 


\section{Page 63 of 81}

\section{Sedimentology}

Figure 15. The Orange littoral sand highway terminates abruptly just east of Praia Amelia, where garnet placers occur (Torquato, 1970). Sand dragged by swell waves from the south feeds the subaqueous spit in front of Praia Amelia, but it is funnelled next in the submarine canyon connected to the Bero mouth. The beach in Namibe Bay is supplied by the Bero River.

Fig. 15

$150 \times 120 \mathrm{~mm}(300 \times 300 \mathrm{DPI})$ 


\section{APPENDIX \\ "Sedimentary processes controlling ultralong cells of littoral transport : placer formation and termination of the Orange sand highway in southern Angola" \\ by Garzanti E., Dinis P., Vermeesch P., Andò S., Hahn A., Huvi J., Limonta M., Padoan, M., Resentini, A., Rittner M., Vezzoli, G.}

\section{A1 - Forward compositional modelling}

Terrigenous sediments are complex mixtures of single detrital minerals and rock fragments supplied in various proportions by numerous different end-member sources (e.g., rivers) to successive segments of a sediment-routing system. If the compositional signature of detritus in each endmember source is known accurately, then the relative contributions from each source to the total sediment load can be quantified mathematically with forward mixing models (Draper and Smith 1981; Weltje, 1997). Several assumptions are made to derive a forward model from a series of compositions (Weltje and Prins 2003): 1) the order of the compositional variables or categories is irrelevant (permutation invariance); 2) the observed compositional variation reflects linear mixing or an analogous process with a superposed measurement error; 3) end-member compositions are fixed; 4) end-member compositions are as close as possible to observed compositions.

\section{Compositional data}

Geological data are often presented in percentages that represent relative contributions of the single variables to a whole (i.e. closed data; Chayes, 1971). This means that the relevant information is contained only in the ratios between variables of the data (i.e., compositions; Pawlowsky-Glahn and Egozcue, 2006). Compositional data are by definition vectors in which each variable (component) is positive, and all components sum to a constant $c$, which is usually chosen as 1 or 100 .

The sample space for compositional data with $D$ variables is not the real space $R^{D}$, but the simplex $S^{D}$ (Aitchison, 1986)

$$
S^{D}=\left\{x=\left[x_{1}, x_{2}, \ldots, x_{D}\right] \quad x_{i}>0 ; \quad i=1,2, \ldots ., D ; \quad \sum_{i=1}^{D} x_{i}=c\right\} .
$$

Pearson (1897) first highlighted problems that arise with the analysis of such compositional datasets. The obvious and natural properties of compositional data are in fact in contradiction with 
most methods of standard multivariate statistics. Principal-component analysis, for instance, may lead to questionable results if directly applied to compositional data. In order to perform standard statistics, a family of logratio transformations from the simplex to the standard Euclidean space were introduced (Aitchison, 1986; Egozcue et al., 2003; Buccianti et al., 2006).

\section{The mixing model}

The forward mixing model (regression model) stipulates a linear relationship between a dependent variable (also called a response variable) and a set of explanatory variables (also called independent variables, or covariates). The relationship is stochastic, in the sense that the model is not exact, but subject to random variation, as expressed in an error term (also called disturbance term).

Let $y$ be the row vector of compositional data with $D$ columns representing variables, $X$ a matrix of end-member compositions with $n$ rows representing observations and $D$ columns representing variables, and $\beta$ a row vector of coefficients with $q=n$ columns representing the proportional contribution of the end members to the observation. In matrix notation, a forward mixing model can be expressed as

(2) $y=\beta X+e$.

The row vector $y$ consists of a non-negative linear combination $\beta$ of $q$ end-member compositions, and $e$ is the row vector of errors with $D$ columns representing variables.

In order to solve the linear-regression problem, we must determine an estimation of the row vector $\beta$ describing a functional linear relation $b$ between a matrix of end-member compositions $X$ and an output row vector $y$. The solution of equation (2) consists in the calculation of the row vector of coefficients $b$ such that

(3) $\hat{y}=b X$,

where $\hat{y}$ is a row vector of calculated compositional data with $D$ columns representing variables. This equation represents a forward mixing model (or "perfect mixing"). The model parameters are subject to the following non-negativity and constant-sum constraints
(4) $\quad \sum_{k=1}^{q} b_{k}=1, \quad b_{k} \geq 0$,
(5) $\quad \sum_{j=1}^{D} x_{k j}=1, \quad x_{k j} \geq 0$.

It follows from equations (4) and (5) that

(6) $\quad \sum_{j=1}^{D} \hat{y}_{j}=c, \quad \hat{y}_{j} \geq 0$,

and thus 
(7) $\quad \sum_{j=1}^{D} e_{j}=0$.

The goodness of fit of the forward mixing model can be assessed by the coefficient of multiple correlation $R$

$$
R=\sqrt{1-(R S S / T S S)},
$$

where $R S S$ is the residual sum of squares

$$
R S S=\sum_{i}\left(y_{i}-\hat{y}_{i}\right)^{2},
$$

and TSS is the total sum of squares

$$
T S S=\sum_{i}\left(y_{i}-\bar{y}\right)^{2} .
$$

The coefficient $R$ departs from a decomposition of the total sum of squares into the "explained" sum of squares (the sum of squares of predicted values, in deviations from the mean) and the residual sum of squares. $R$ is a measure of the extent to which the total variation of the dependent variable is explained by the forward model. The $R$ statistic takes on a value between 0 and 1 . A value of $R$ close to 1 , suggesting that the model explains well the variation in the dependent variable, is obviously important if one wishes to use the model for predictive or forecasting purposes. In provenance studies, the coefficient of multiple correlation $R$ measures the similarity between theoretical detrital modes of sediments supplied by different combinations of diverse end-members sources and the observed detrital mode of one trunk-river sediment or sedimentary rock in the basin.

\section{A2 - Calculation of zircon and monazite concentration}

Chemical data allow us to assess precisely the amount of rare ultradense minerals hosting large amounts of specific trace elements such as zircon or monazite. Assuming that zircon contains $\sim 60 \%$ $\mathrm{ZrO}_{2}$ and that its contribution to bulk-sample $\mathrm{Zr}$ increases from $\leq 60 \%$ in heavy-mineral-depleted sands to $\leq 100 \%$ in placer deposits (Garzanti et al., 2010), beaches and dunes in the Skeleton Coast and Moçamedes Desert are calculated to contain $\sim 0.04 \%$ zircon. This value appears to be somewhat higher than the zircon concentration estimated for Orange River $(\sim 0.02 \%)$, Coastal Namib dune $(\sim 0.03 \%)$ and beach sands $(\sim 0.01 \%)$, as well as for sands of rivers draining the Damara orogen in central Namibia $(\sim 0.02 \%)$, which supports progressive concentration of ultradense minerals in coastal sediments along the littoral cell.

Similar calculations can be made for monazite, based on assumed concentrations of LREE and Th in monazite and monazite contributions for these elements in the bulk sample. Beaches and dunes in 
both Skeleton Coast and Moçamedes Desert are thus calculated to contain $\sim 0.003 \%$ monazite, a value intermediate between those calculated for Coastal Namib dune and beach sands $(\sim 0.002 \%)$ and for the Orange River and Namibian rivers draining the Damara orogen $(\sim 0.004 \%)$.

In the Praia do Navio dune semi-placer, zircon concentration is estimated to be $\sim 0.64 \%$ (1.8\% based on point counting), a full order of magnitude more than in neutral sand. Monazite, undetected optically, is estimated to represent $0.014 \%$ of the bulk sample based on chemical data. In Coastal Namib beach placers, zircon is estimated to reach $\sim 1.4 \%$ and monazite $\sim 0.03 \%$. In the Vanesinha and Praia do Navio beach placers, zircon concentration is assessed at $\sim 2.8 \%$ and $\sim 1.5 \%(2.0 \pm 0.3 \%$ and $1.0 \pm 1.0 \%$ based on point and grain counting), and monazite concentration at $\sim 0.05 \%$ and $\sim 0.02 \%(0.3 \pm 0.3 \%$ for both beach placers based on point and grain counting).

In river and beach sands north of Namibe, equivalent values for zircon concentration are estimated from chemical data and point counting $(\sim 0.02 \%)$. Zircon concentration is estimated to be $\sim 0.15 \%$ in the Inamangando outer berm semi-placer ( $0.29 \%$ based on point counting) and $\sim 1.5$ in the Bentiaba placer ( $2.8 \pm 0.5 \%$ based on point and grain counting). Monazite is estimated to represent $\sim 0.004 \%$ of river and beach sands, where it was undetected optically, one order of magnitude more in the Inamangando outer berm semi-placer $(\sim 0.04 \%)$, and another order of magnitude more in the Bentiaba placer $(0.68 \%$ versus $0.64 \%$ based on point and grain counting).

\section{TABLE AND FIGURE CAPTIONS}

Table A1. Sample location. Location of the studied sediment samples with year of sampling (see also the Google Earth file Mocamedes.kmz). Locality names in the Moçamedes Desert mostly after Torquato (1974).

Table A2. Sand petrography. $G S Z=$ grain size. $Q=$ quartz $(\mathrm{Qp}=$ polycrystalline $) ; \mathrm{F}=$ feldspars $(\mathrm{KF}=\mathrm{K}$-feldspar; $\mathrm{P}=$ plagioclase; $\mathrm{Mic}=$ cross-hatched microcline $) ; \mathrm{L}=$ aphanitic lithic grains $(\mathrm{Lv}=$ volcanic and subvolcanic; $\mathrm{Lc}=$ carbonate; $\mathrm{Lh}=$ chert; $\mathrm{Lp}=$ shale/siltstone; $\mathrm{Lms}=$ low-rank metasedimentary; $\quad \mathrm{Lmv}=$ low-rank metavolcanic; $\mathrm{Lmf}=$ medium/high-rank metapelite/metapsammite/metafelsite; $\mathrm{Lmb}=$ medium/high-rank metabasite; $\mathrm{Lu}=$ ultramafic). $\mathrm{HM}=$ heavy minerals. Rock fragments: $\mathrm{V}=$ volcanic; $\mathrm{Vm}=$ intermediate and mafic volcanic; $\mathrm{M}=$ metamorphic; $\mathrm{Mb}=$ mafic metamorphic; n.d. = not determined. The Metamorphic Indices MI and $\mathrm{MI}^{*}$ express the average metamorphic rank of rock fragments in each sample. MI varies from 0 (detritus shed by exclusively sedimentary and volcanic cover rocks) to 500 (very-high-rank detritus 
shed by exclusively high-grade basement rocks). MI* considers only metamorphic rock fragments, and thus varies from 100 (very-low-rank detritus shed by exclusively very low-grade metamorphic rocks) to 500 (Garzanti and Vezzoli, 2003).

Table A3. Heavy minerals. $\mathrm{HM}=$ heavy minerals; $\mathrm{tHM}=$ transparent heavy minerals; $\mathrm{HMC}$ and tHMC = total and transparent-heavy-mineral concentration indices (Garzanti and Andò, 2007); RF= rock fragments; n.d. = not determined. The ZTR index (sum of zircon, tourmaline and rutile over total transparent heavy minerals) evaluates the "chemical durability" of the detrital assemblage (Hubert 1962). The HCI (Hornblende Colour Index) and MMI (Metasedimentary Minerals Index) vary from 0 in detritus from greenschist-facies to lowermost amphibolite-facies rocks yielding exclusively blue/green amphibole and chloritoid, to 100 in detritus from granulite-facies rocks yielding exclusively brown hornblende and sillimanite, and are used to estimate the average metamorphic grade of metaigneous and metasedimentary source rocks, respectively (Andò et al. 2014).

Table A4. Raman point-counting of beach placers in the Moçamedes Desert and coastal Namib Erg. Composition of opaque Fe-Ti-Cr oxides is also indicated (magnetite* includes all $\mathrm{Fe}$ oxides and hydroxides; ilmenite* includes leucoxene). Carefully micro-quartered splits of placer sand were mounted on glass slides. All counted grains were identified under the Raman spectroscope (method described in detail in Andò et al., 2011). Each single grain within the counted area was identified on a photograph and numbered for grain counting and on a regularly spaced grid for point counting (Andò and Garzanti, 2014). Raman spectroscopy analyses were carried out with a Raman Renishaw inVia directly on loose grains spread on glass slides. After calibration using the $520.6 \mathrm{~cm}^{-1}$ Raman band of silicon internal standard, spectra were obtained by focusing the $532 \mathrm{~nm}$ laser beam on the grain surface for $\sim 20 \mathrm{~s}$ for offshore samples. Raman counting of placer samples was carried out taking care to avoid heating of opaque Fe-Ti-Cr oxides by reducing the laser power down to $10 \%$ and by acquiring each spectrum for $\sim 0.5 \mathrm{~s}$ in 60 cycles. HMC and tHMC $=$ Heavy Mineral and transparent Heavy Mineral Concentration. \&HM= other heavy minerals (including apatite, tourmaline, kyanite, Ti oxides of possibly authigenic origin, and few unidentified rare minerals).

Table A5. Discrimination of detrital pyroxenes in onshore and offshore sediments of the Orange littoral cell. Identification of clinopyroxenes, orthopyroxenes and pyroxenoids is based on diagnostic Raman peaks in the medium-frequency (around $666 \mathrm{~cm}^{-1}$ ) and high-frequency (around $1000 \mathrm{~cm}^{-1}$ ) regions (Huang et al. 2001; Wang et al., 2001; Tribaudino et al., 2012; Andò and 
Garzanti, 2014). Augite prevails over diopside in most samples, with subordinate pigeonite, minor hypersthene, and sporadic pyroxenoid and enstatite.

Table A6. Composition of detrital garnets in beach placers of the Moçamedes Desert. Discrimination within the garnet isomorphous series is based on diagnostic Raman peaks, an efficient approach that allows rapid assessment of garnet chemistry (Bersani et al. 2009). The analysed detrital garnets are all pyralspites, with andradite and grossular molecules $\leq 10 \%$. Most grains resulted to be almandine with pyrope molecule $\leq 36 \%$, several nearly pure almandine, and several almandine with either spessartine or both pyrope and spessartine molecules. A few spessartine garnets, with or without almandine molecule, are also found. The pyrope molecule reaches $50 \%$ at most in a few grains also containing spessartine and almandine.

Table A7. Measured grain density and comparison with SRD values, heavy-mineral concentration indices, and percentages of ultradense minerals. Grain density was measured on a small ( $1 \mathrm{~g})$, micro-quartered fraction of the sand sample placed in a suitably small aluminium container, and weighed by a high-precision Mettler Toledo ${ }^{\mathrm{TM}}$ balance $(0.1 \mathrm{mg}$ readability) first in air and next immersed in deionized water. It is essential to wet the grains before immersion and take every possible care to avoid floating owing to surface tension. Mud must be eliminated by wet sieving. Grain density $\delta$ is thus obtained as: $\delta=\mathrm{W}_{\text {in air }} /\left(\mathrm{W}_{\text {in air }}-\mathrm{W}_{\text {in water }}\right) \cdot \delta_{\text {water }}$, where the weight of the sand $\mathrm{W}$ is obtained as the total weight (sand + container) less the weight of the container, and $\delta_{\text {water }}$ is calculated at the measured temperature (e.g., $0.9982 \mathrm{~g} / \mathrm{ml}$ at $20^{\circ} \mathrm{C}$ ).

The HMC and tHMC (Heavy Mineral Concentration and transparent Heavy Mineral Concentration) indices are calculated as the volume percentage of total (HMC) and transparent (tHMC) heavy minerals, and the SRD (Source Rock Density) index as the weighted average density of extrabasinal terrigenous grains (Garzanti and Andò, 2007). The SRD index represents a maximum estimate of grain density, because an ideal density of each extrabasinal detrital component is assumed in its calculation, neglecting inclusions and weathering-induced alteration. Conversely, the measured density represents a minimum estimate of grain density in case of imperfect elimination of air from intergranular and intragranular pores. Moreover, the sediment may contain intrabasinal grains with low-density (e.g., rip-up clasts, glaucony pellets), intragranular porosity (e.g., shells of gastropods, tests of radiolaria or foraminifera), or irregular shape preventing the complete elimination of air bubbles during immersion. In order to increase analytical precision, four replicate measurements at least were made for each sample, and if good agreement was obtained then the maximum value was considered as the most accurate estimate. We observed that the discrepancy between the calculated SRD index and the measured grain density tends to increase in samples richer in opaque 
ferromagnetic minerals. The latter are generally mixtures of different oxides altered to various degrees in secondary hematite or leucoxene, and their density cannot be estimated accurately. Moreover, they tend to form grain clusters not easy to partition evenly during sample quartering. The largest discrepancies were caused by magnetite grains forming irregularly distributed lumps in the Inamangando outer berm semi-placer sample, which required 14 replicate measures on separately quartered fractions to obtain a reliable measure.

Table A8. Sand geochemistry (analyses made at ACME Laboratories, Vancouver; for information on adopted procedures, geostandards used and precision for various elements of group 4A-4B and code LF200 see http://acmelab.com). Elements analysed by aqua regia digestion (a.r.d.) are commonly underestimated because of only partial leaching of refractory minerals. Chemical weathering indices are defined in Nesbitt and Young (1982; CIA), Fedo et al. (1995; PIA), Harnois (1988; CIW), Garzanti et al. (2014; CIX), and Parker (1970; WIP). In order to avoid bias caused by hydraulic concentration of heavy minerals hosting Ti, REE and Th, $\alpha^{\mathrm{Al}}$ values were normalized to non-mobile $\mathrm{Al}$ (Garzanti et al., 2014). The Eu anomaly is the measured chondrite-normalized Eu value over the value that Eu would have in a linear extrapolation between chondrite-normalized values of Sm and Gd. The Ce anomaly, indicative of redox state, is the measured PAAS-normalized $\mathrm{Ce}$ value over the value that $\mathrm{Ce}$ would have in a linear extrapolation between PAAS-normalized values of $\mathrm{La}$ and Pr. MREE is the average of $\mathrm{Eu}, \mathrm{Gd}, \mathrm{Tb}$ and Dy normalized to PAAS, MREE* the average of LREE (La, Ce, Pr, Nd) and HREE (Er, Tm, Yb, Lu) values (Haley et al., 2004). The chondrite-normalized $\mathrm{La}_{\mathrm{N}} / \mathrm{Yb}_{\mathrm{N}}, \mathrm{La}_{\mathrm{N}} / \mathrm{Sm}_{\mathrm{N}}, \mathrm{Gd}_{\mathrm{N}} / \mathrm{Ho}_{\mathrm{N}}$, and $\mathrm{Ho}_{\mathrm{N}} / \mathrm{Yb}_{\mathrm{N}}$ ratios are also given. $\mathrm{GSZ}=$ grain size; D.L. $=$ detection limit; n.d. $=$ not determined.

Figure A1. Chemical composition of detrital garnets. Beach placers in the Moçamedes Desert contain pyralspite garnets with compositions that overlap widely the distribution of detrital garnets in Skeleton coast dunes, confirming common, long-distance provenance from the Orange River and subordinately from rivers draining amphibolite-facies metasediments of the Damara orogen in central Namibia (Gray et al., 2008). Classical Mg-(Fe+Mn)-Ca (Mange and Morton, 2007) and MgMn-Ca (Teraoka et al., 1997; Win et al., 2007) ternary plots allow us to classify Moçamedes garnets as mainly of type $\mathrm{Bi}$ and subordinately of type A, suggesting provenance from amphibolite-facies rocks metamorphosed under low to intermediate $\mathrm{P} / \mathrm{T}$ conditions and subordinately from highergrade rocks. $\mathrm{XMg}, \mathrm{XFe}, \mathrm{XMn}$ and $\mathrm{XCa}$ are molecular proportions of $\mathrm{Fe}^{2+}, \mathrm{Mg}, \mathrm{Ca}$ and $\mathrm{Mn}(\mathrm{XMg}$ is at the apex of both triangles). 


\section{APPENDIX B}

\section{U-Pb detrital zircon geochronology of modern sands from northern Namibia and southern}

Angola (analyses made at the London Geochronology Centre, University College London). We used ${ }^{206} \mathrm{~Pb} /{ }^{238} \mathrm{U}$ and ${ }^{207} \mathrm{~Pb} /{ }^{206} \mathrm{~Pb}$ ages for zircons younger and older than $1100 \mathrm{Ma}$, respectively; grains with $>10 \%$ age discordance were discarded. No common $\mathrm{Pb}$ correction was applied. Grains with $+5 /-15 \%$ age discordance were discarded.

\section{CITED REFERENCES}

Aitchison, J., 1986. The statistical analysis of compositional data. Chapman and Hall, London.

Andò, S., Garzanti, E., 2014. Raman spectroscopy in heavy-mineral studies. In: Scott, R., Smyth. H., Morton, A., Richardson, N. (Eds.), Sediment provenance studies in hydrocarbon exploration and production. Geological Society London, Special Publications 386, pp. 395-412.

Andó, S., Morton, A., Garzanti, E., 2014. Metamorphic grade of source rocks revealed by chemical fingerprints of detrital amphibole and garnet. In: Scott, R., Smyth. H., Morton, A., Richardson, N. (Eds.), Sediment provenance studies in hydrocarbon exploration and production. Geological Society London, Special Publications 386, pp. 351-371.

Andò, S., Vignola, P., Garzanti, E., 2011. Raman counting: a new method to determine provenance of silt. Rendiconti Lincei, 22, 327-347.

Bersani, D., Ando`, S., Vignola, P., Moltifiori, G., Marino, I.G., Lottici, P.P., Diella, V., 2009. MicroRaman spectroscopy as a routine tool for garnet analysis. Spectrochimica Acta, Part A, 73, 484491.

Buccianti, A., Mateu-Figueras, G., Pawlowsky-Glahn, V. (Eds.), 2006. Compositional Data Analysis in the Geosciences: From Theory to Practice. Geological Society, Special Publications 264, London.

Chayes, F., 1971. Ratio correlation: A manual for students of petrology and geochemistry. Univ. Chicago Press, Chicago (USA), 99 p.

Draper, N., and Smith, H. 1981. Applied regression analysis (2nd ed.). New York, Wiley, 709 p.

Egozcue, J. J., Pawlowsky-Glahn, V., Mateu-Figueraz, G., Barceló-Vidal, C., 2003. Isometric logratio transformations for compositional data analysis. Math. Geol. 35, 279-300.

Fedo, C.M., Nesbitt, H.W., Young, G.M., 1995. Unraveling the effects of potassium metasomatism in sedimentary rocks and paleosols, with implications for paleoweathering conditions and provenance. Geology, 23, 921-924.

Garzanti, E., Andò, S., 2007. Heavy-mineral concentration in modern sands: implications for provenance interpretation. In: Mange, M.A., Wright, D.T. (Eds.), Heavy Minerals in Use. Elsevier, Amsterdam, Developments in Sedimentology Series 58, pp.517-545. 
Garzanti, E., Vezzoli, G., 2003. A classification of metamorphic grains in sands based on their composition and grade. Journal of Sedimentary Research, 73, 830-837.

Garzanti, E., Andó, S., France-Lanord, C., Vezzoli, G., Najman, Y., 2010. Mineralogical and chemical variability of fluvial sediments. 1. Bedload sand (Ganga-Brahmaputra, Bangladesh). Earth and Planetary Science Letters, 299, 368-381.

Garzanti, E., Vermeesch, P., Padoan, M., Resentini, A., Vezzoli, G., Andò, S., 2014. Provenance of passive-margin sand (southern Africa). The Journal of Geology, 122, 17-42.

Gray, D.R., Foster, D.A., Meert, J.G., Goscombe, B.D., Armstrong, R., Trouw, R.A.J., Passchier, C.W., 2008. A Damara Orogen perspective on the assembly of southwestern Gondwana. In: Pankhurst, R.J., Trouw, R.A.J., Brito Neves, B.B., De Wit, M.J. (Eds.), West Gondwana: preCenozoic correlations across the South Atlantic region. Geological Society of London, Special Publication 294, 257-278.

Haley, B.A., Klinkhammer, G.P., McManus, J., 2004. Rare earth elements in pore waters of marine sediments. Geochimica Cosmochimica Acta, 68,1265-1279.

Harnois, L., 1988. The CIW index: a new chemical index of weathering. Sedimentary Geology, 55, 319-322.

Huang, E., Chen, C.H., Huang, T., Lin, E.H., Xu, J.A., 2000. Raman spectroscopic characteristics of Mg-Fe-Ca pyroxenes. American Mineralogist, 85, 473-479.

Hubert, J.F. 1962. A zircon-tourmaline-rutile maturity index and the interdependence of the composition of heavy minerals assemblages with the gross composition and texture of sandstones. Journal of Sedimentary Petrology 32:440-450.

Mange, M.A., Morton, A.C., 2007. Geochemistry of heavy minerals. In: Mange, M.A., Wright, D.T. (Eds.), Heavy Minerals in Use. Elsevier, Amsterdam, Developments in Sedimentology, 58, 345391.

Nesbitt, H.W., Young, G.M., 1982. Early Proterozoic climates and plate motions inferred from major element chemistry of lutites. Nature, 299, 715-717.

Parker, A., 1970. An index of weathering for silicate rocks. Geological Magazine, 107, 501-504.

Pawlowsky-Glahn, V., Egozcue, J.J., 2006. Compositional data and their analysis: an introduction. In: Buccianti, A., Mateu-Figueras, G., Pawlowsky- Glahn, V. (Eds.), Compositional data analysis in the geosciences: From theory to practice. Geological Society of London Special Publications 264, pp. $1-10$.

Pearson, K., 1897. Mathematical contributions to the theory of evolution. On a form of spurious correlation which may arise when indices are used in the measurement of organs. Proceedings of the Royal Society of London LX, 489-502.

Teraoka, Y., Suzuki, M., Hayashi, T., Kawakami, K., 1997. Detrital garnets from Paleozoic and Mesozoic sandstones in the Onogawa Area, East Kyushu, Southwest Japan. Bulletin of the Faculty of Education Hiroshima University, 19, 87-101 (in Japanese, English abstract).

Torquato, J.R., 1974. Geologia do sudoeste do Moçamedes e suas relaçoes con a evoluçao tectonica de Angola. Tese de doutoramento, Instituto de Geociencias, Universidade de Săo Paulo, 343 p. 
Tribaudino, M., Mantovani, L., Bersani, D., Lottici, P.P., 2012. Raman spectroscopy of (Ca, Mg) $\mathrm{MgSi}_{2} \mathrm{O}_{6}$ clinopyroxenes. American Mineralogist, 97, 1339-1347.

Wang, A., Jolliff, B.L., Haskin, L.A., Kuebler, K.E., Viskupic, K.M., 2001. Characterization and comparison of structural and compositional features of planetary quadrilateral pyroxenes by Raman spectroscopy. American Mineralogist, 86, 790-806.

Weltje, G. J., 1997. End-member modelling of compositional data: numerical statistical algorithms for solving the explicit mixing problem. Math. Geol. 29, 503-549.

Weltje, G.J., Prins, M.A., 2003. Muddled or mixed? Inferring palaeoclimate from size distributions of deep-sea clastics. Sedimentary Geology 162, 39-62.

Win, K.S., Takeuchi, M., Tokiwa, T., 2007. Changes in detrital garnet assemblages related to transpressive uplifting associated with strike-slip faulting: an example from the Cretaceous System in Kii Peninsula, southwest Japan. Sedimentary Geology, 201, 412-431. 
Table A1

1

Sample River/Cruise Site

3

4

5

10

11

$18 \quad S 4954$

$19 \$ 4955$

$20 \$ 4956$

$21 \quad S 4802$

\section{MOÇAMEDES DESERT}

23 S4804

$24 \quad \$ 4805$

$25 \quad \$ 4774$

$26 \quad \$ 4957$

$27 \quad 54961$

$28 \quad 54958$

29 P4958

$30 \mathrm{~S} 4960$

$31 \quad \$ 4959$

$32 \quad \mathrm{P} 4959$

$33 \quad S 5059$

55058

$36 \quad 55057$

$37 \quad 55056$

$38 \quad 55055$

$39 \quad 55054$

$40 \quad 55053$

41 HOARUSIB \& CUNENE RIVER SYSTEM

43

45

46

47

48

49

50

5

53

54

55

56

60

\section{ANGOLAN COAST}

Carujamba

Lucira

Inamangando

Inamangando

Inamangando

Baia das Salinas

Bentiaba

Bentiaba

Bentiaba

Chapeu Armado

Mariquita

Giraul

Namibe

Namibe

Subida Grande

Curoca mouth

Curoca mouth

Nonguai

Tombua

Tombua outer spit

Tombua

Vanesa

Cova dos Medos

Vanesinha

Vanesinha

Praia do Navio

Praia do Navio

Praia do Navio

Riscos

Riscos

Saco dos Tigres

Praia dos Esponjas

Praia dos Esponjas

Foz do Cunene

Foz do Cunene

Purros

Matala

Techiulo

Techango

Caculuvar

Caculuvar confluenct Omutele
Cunener Ruacana

Ehomba

Chitado

Etengua

Oryeheke

Epupa Falls

Van Zyl's Pass

Otyoyonoka

Foz do Cunene

\section{ES}

GeoB1019-3

GeoB1020-1

GeoB1021-3

GeoB1022-2

GeoB1704-1

GeoB1705-1

$1080 \mathrm{~A}$

$1080 \mathrm{~A}$

$1080 \mathrm{~B}$
Latitude

Longitude

S 135158

E 123114

S 135919

E 123101

E 122309

E 122310

E 122538

E 122038

E 122246

E 122211

E 122211

E 122038

E 121704

E 120918

E 121005

E 120850

E 120154

E 115524

E 115438

E 120440

E 115118

S 154754

S 154720

S 154756

S 155709

S 160124

S 160925

S 160925

S 161625

S 161623

S 161623

S 163000

S 163000

S 164827

$\mathrm{S} 170500$

S 170500

S 171524

S 171524

S 184408

S 144438

S 163146

S 163815

S 164612

S 172430

S 172520

S 171850

S 172820

S 165920

S 1700

S 173740

S 173920

S 171524

S 171029

S 171007

S 171034

S 171024

S 192424

S 193018

S 163335

S 163335

S 163336

E 114908

E 115154

E 114606

E 114847

E 114736

E 114736

E 114844

E 114835

E 114835

E 114930

E 114930

E 114813

E 114508

E 114508

E 114518

E 114518

E 125642

E 150221

E 145222

E 145416

E 145455

E 1413

E 140030

E 134740

E 130340

E 132210

E 1315

E 124250

E 123800

E 114518

E 113850

E 112400

E 111753

E 113642

E 112354

E 104912

E 104912

E 104912

Facies
beach
fluvial
outer berm
inner berm
fluvial
beach
fluvial
beach placer
beach
beach
beach
fluvial
fluvial
beach
beach
fluvial
beach
fossil dune

Country

Collected by

Year

E 113253

\section{Angola}

E.Garzanti

E.Garzanti

E.Garzanti

E.Garzanti

E.Garzanti

E.Garzanti

E.Garzanti

E.Garzanti

E.Garzanti

E.Garzanti

E.Garzanti

E.Garzanti

E.Garzanti

E.Garzanti

E.Garzanti

E.Garzanti

E.Garzanti

P.Dinis

2015

2015

2015

2015

2015

2015

2015

2015

2015

2015

2015

2015

2015

2015

2015

2015

2015

2014

2014

beach

eolian dune

beach

eolian dune

beach

beach placer

eolian dune

beach

beach placer

eolian dune

beach

beach

eolian dune

beach

eolian dune 
1 River / (facies 2 SOUTHERN ANGOLAN COAST 3 4 Carujamba (outer berm) 7 (inner bern 8 (beach) 9 Bentiaba $10^{\text {Bentiaba }}$

11 (beach) 12 (beach) $14^{\text {Giraul }}$ $14^{\text {Giraul }}$
$15^{\text {Bero }}$ $15^{\text {Bero }}$ (beach) $\begin{array}{ll}16 & \text { (beach) } \\ 17 & \text { (beach) }\end{array}$ 1 gossil dun 19 Curoca 20 1MOÇAMEDES

21MOÇAMEDES DESER

$\begin{array}{lll}22 & \text { (outer spit) } & \text { Tombua } \\ 23 & \text { (eolian dune) } & \text { Tombua }\end{array}$

$\begin{array}{lll}23 & \text { (eolian dune) } & \text { Tombua } \\ 24 & \text { (beach) } & \text { Vanesa }\end{array}$

25 (eolian dune) Cova dos Medos (beach)

(eolian dune)
(beach)

(eolian dune)

(beach)

(eolian dune)

(beach) Vanesinha

Praia do Navio

Praia do Navio

Riscos

Riscos
Saco dos Tigres

Praia dos Esponjas S5056 A.Resentini 325

34

35 36 (beach) Foz do Cunene 3 HOARUSIB \& CUNENE RIVER SYSTEN

\section{Hoarusib Purros}

39 Cunene Matala

40 Mucope Techiulo

41 Caculuvar Techang

42 Caculuvar confluence Omutele

$43^{C}$ unene Ruacana

450ndoto

460 muhongo

470 muhong

48Cunene

490tjinjange

50 Marienflu

51Cunene

Ehomba

Chitado

Oryeheke

Epupa Falls

Van Zyl's Pass

Otyoyonoka

Foz do Cunene

\section{OFFSHORE CORE TOP SAMPLES}

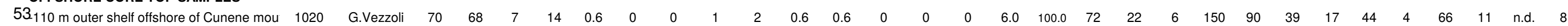

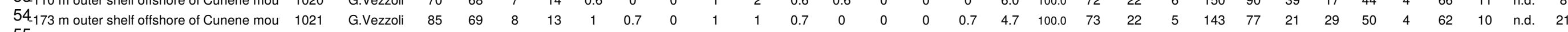

Sample Operator GSZ Q $\quad$ KF $\quad P \quad$ Lv $\quad$ Lc $\quad$ Lh $\quad$ Lp $\quad$ Lms $\quad$ Lmv $\quad$ Lmf $\quad$ Lmb $\quad$ Lu $\quad$ mica $\quad H M$

S4941 A.Resentini 390

$\begin{array}{lllllllllll}12 & 36 & 0 & 0.3 & 0 & 0 & 0 & 0.3 & 2 & 0.9 & 0\end{array}$

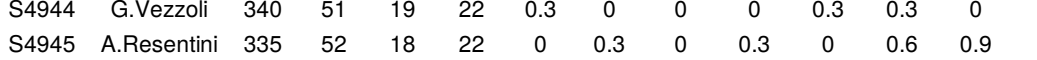



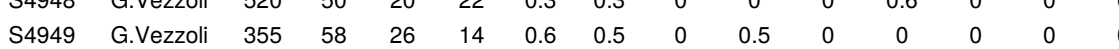

S4950 A.Resentini $6 \begin{array}{llllllllllll}670 & 59 & 20 & 19 & 0 & 0.3 & 0 & 0 & 0 & 0.3 & 0.3 & 0.3\end{array}$

$\begin{array}{cccccccccccccccc}\text { S4951 } & \text { A.Resentini } & 325 & 53 & 17 & 23 & 0 & 0 & 0 & 0 & 0 & 0 & 0.6 & 0 \\ \text { S4952 } & \text { G.Vezzoli } & 230 & 42 & 16 & 32 & 0 & 0 & 0.3 & 0.7 & 0.3 & 0.3 & 2 & 0.3 & 0\end{array}$



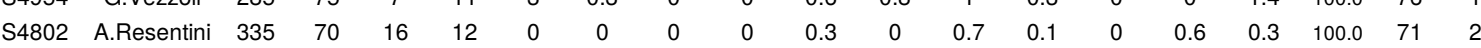

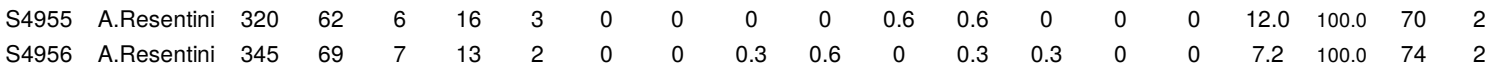

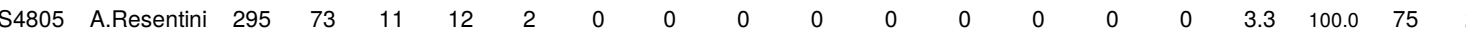

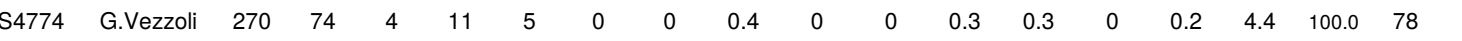

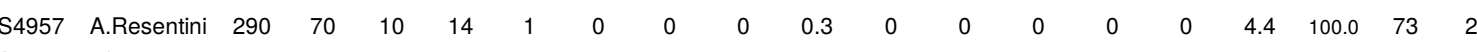

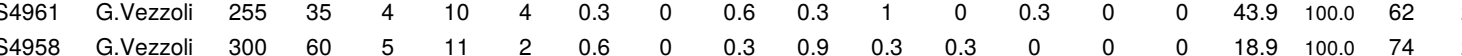



$\begin{array}{lll}11.7 & 100.0 & 72\end{array}$

$\begin{array}{llll}2.0 & 100.0 & 75\end{array}$

$\begin{array}{llll}16.7 & 100.0 & 69 & 29\end{array}$

$\begin{array}{lllll}1.2 & 100.0 & 75 & 22 \\ 3.7 & 100.0 & 67 & 30 & 0 \\ 1.2 & 100.0 & 66 & 29\end{array}$

$\begin{array}{llll}1.2 & 100.0 & 66 & 29\end{array}$

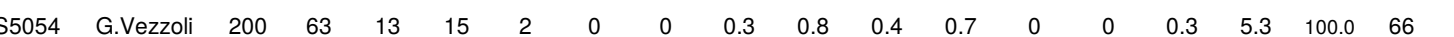

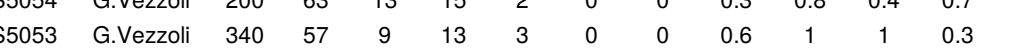

54948 G.Vezzoli $520 \quad 50 \quad 20028 \quad 0.300$

S3938 G.Vezzoli $2 \begin{array}{lllllllllllllllllllllllllllllll} & 200 & 63 & 16 & 10 & 1 & 3 & 0 & 0 & 2 & 0.3 & 3 & 0 & 0 & 1 & 0 & 100.0 & 64 & 27 & 9 & 284 & 244 & 42 & 18 & 40 & 53 & 39 & 28 & 60 & 6\end{array}$





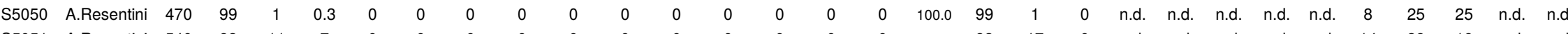



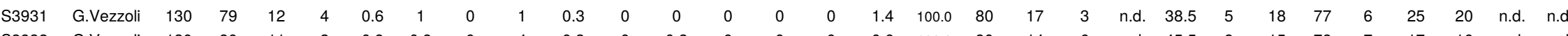

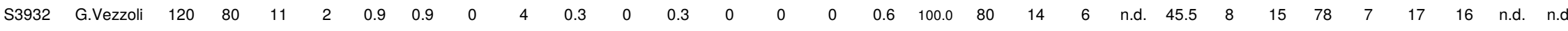

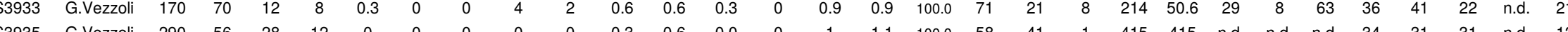
$\begin{array}{lllllllllllllllllllll}0 & 0.3 & 0.6 & 0.0 & 0 & 1 & 1.1 & 100.0 & 58 & 41 & 1 & 415 & 415 & \text { n.d. } & \text { n.d. } & \text { n.d. } & 34 & 31 & 31 & \text { n.d. } & 12\end{array}$

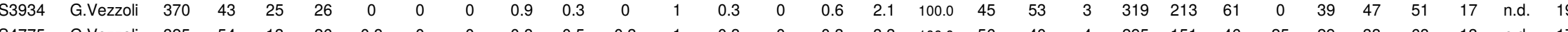
$\begin{array}{llllllllllllllllllllllllllllllllll}\text { S3936 G.Vezzoli } & 220 & 58 & 11 & 11 & 0 & 0.7 & 0 & 0.4 & 0 & 0.8 & 4 & 2 & 0 & 3 & 9.3 & 100.0 & 65 & 25 & 10 & 383 & 362 & 81 & 5 & 14 & 28 & 49 & 19 & \text { n.d. } & 35\end{array}$

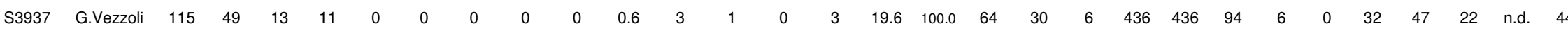

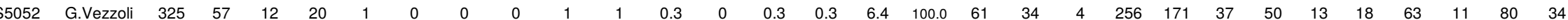




\section{Page 77 of 81}

1

2 Table A4

3

6

8

$10 \mathrm{P} 4948$ foreshore beach placer Bentiaba

$11 \mathrm{P} 4958$ foreshore beach placer Vanesinha

P4959 foreshore beach placer Praia do Navic

13P4336 foreshore beach placer Shawnee

14 P4330 foreshore beach placer Bayview

15

16

17

18

19

20

2 bpaque Fe-Ti-Cr oxides

22

$2 \$ 4948$ foreshore beach placer Bentiaba

244958 foreshore beach placer Vanesinha

$\begin{array}{lll}2 \$_{4} & \text { foreshore beach placer } \text { foreshore beach placer Praia do Navic } 75\end{array}$

26

28

29

30

31

32

3

34

35

36

3

39

40

41

42

43

4

45

46

48

48

50

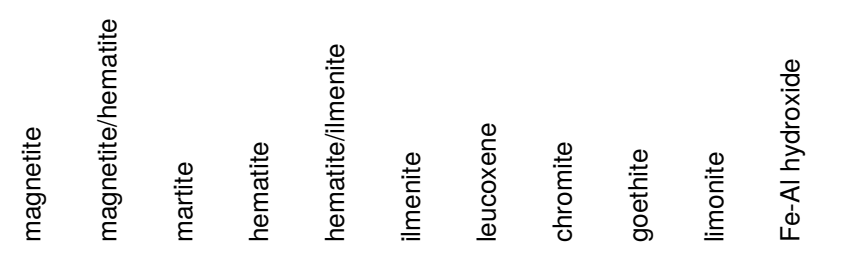

$\begin{array}{lllllllllllll}\text { F.Crotti } & 30 & 17 & 31 & 8 & 0 & 14 & 0 & 0.6 & 0 & 0 & 0 & 100.0\end{array}$

$\begin{array}{lllllllllllll}\text { F.Crotti } & 16 & 3 & 27 & 6 & 2 & 8 & 1 & 3 & 11 & 13 & 9 & 100.0\end{array}$

$\begin{array}{lllllllllllll}\text { F.Crotti } & 23 & 5 & 46 & 13 & 0 & 10 & 0 & 4 & 0 & 0 & 0 & 100.0\end{array}$ 


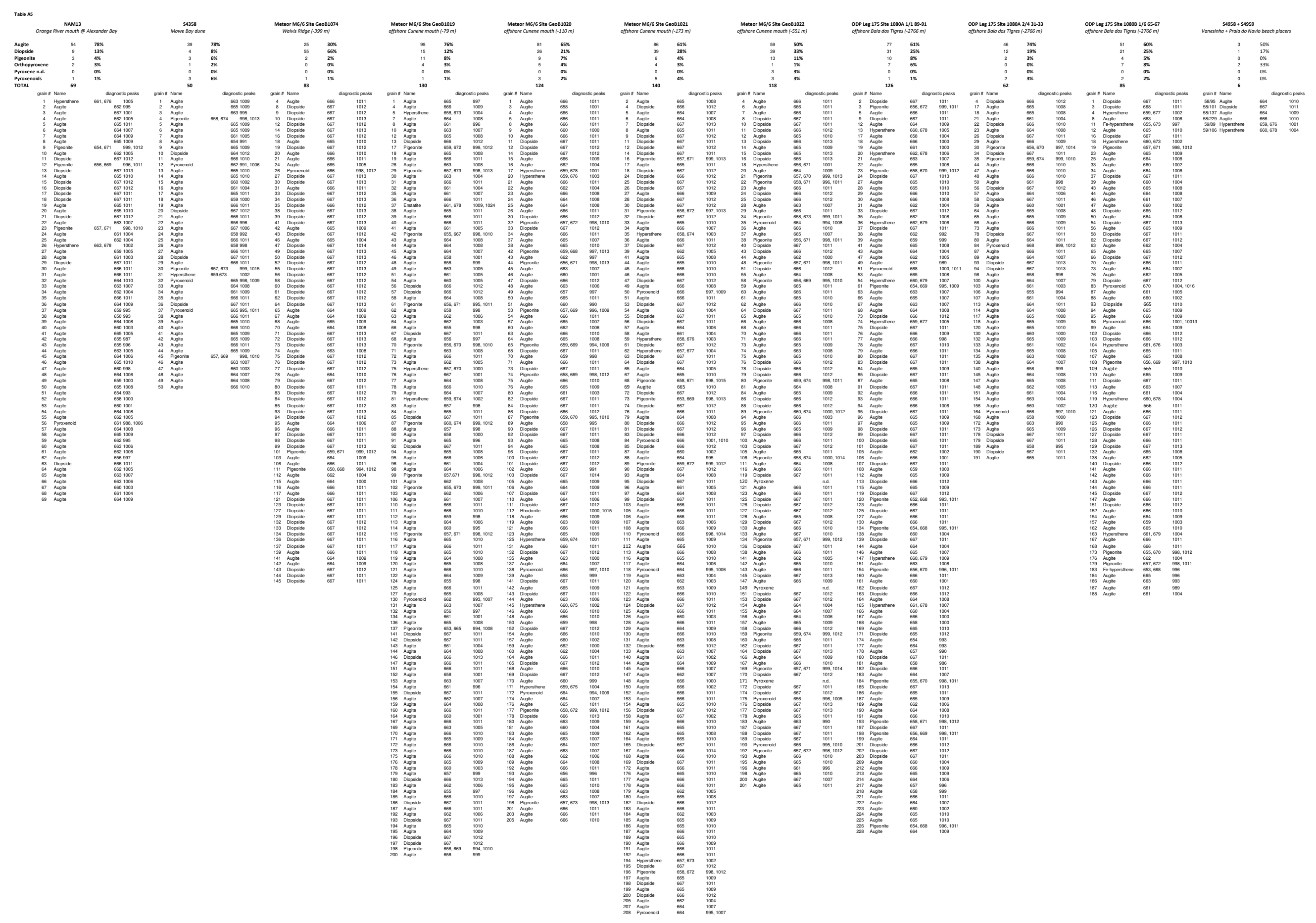


Selected Raman peaks $\left(\mathrm{cm}^{-1}\right)$

Composition from Raman peaks distribution (mol\%)

Grain $n^{\circ}$ Peak 1 Peak 2 Peak 3 Peak 4 Peak 5 Peak 6 almandine pyrope spessartine andradite grossular

Sample P4958 Vanesinha beach placer

\begin{tabular}{|c|c|c|c|c|c|c|c|c|c|c|c|}
\hline 1 & 214.0 & 344.3 & 371.3 & 554.6 & 857.7 & 910.3 & $72 \%$ & $0 \%$ & $26 \%$ & $2 \%$ & $0 \%$ \\
\hline 4 & 211.0 & 344.7 & 370.2 & 555.8 & 861.0 & 914.4 & $84 \%$ & $12 \%$ & $2 \%$ & $2 \%$ & $0 \%$ \\
\hline 12 & 212.5 & 342.2 & 369.4 & 554.2 & 855.3 & 909.2 & $86 \%$ & $0 \%$ & $4 \%$ & $10 \%$ & $0 \%$ \\
\hline 21 & 214.0 & 344.9 & 367.2 & 555.4 & 859.1 & 912.2 & $86 \%$ & $6 \%$ & $2 \%$ & $6 \%$ & $0 \%$ \\
\hline 22 & 209.5 & 347.7 & 371.7 & 554.9 & 854.0 & 909.6 & $42 \%$ & $14 \%$ & $40 \%$ & $4 \%$ & $0 \%$ \\
\hline 23 & 216.9 & 348.5 & 375.1 & 552.8 & 857.5 & 904.9 & $60 \%$ & $18 \%$ & $4 \%$ & $10 \%$ & $8 \%$ \\
\hline 25 & 206.6 & 341.9 & 369.7 & 556.8 & 857.7 & 911.0 & $86 \%$ & $0 \%$ & $14 \%$ & $0 \%$ & $0 \%$ \\
\hline 27 & 208.4 & 343.2 & 369.1 & 555.3 & 856.8 & 911.9 & $88 \%$ & $6 \%$ & $0 \%$ & $6 \%$ & $0 \%$ \\
\hline 28 & 209.6 & 342.6 & 370.1 & 555.3 & 857.7 & 911.4 & $86 \%$ & $2 \%$ & $8 \%$ & $4 \%$ & $0 \%$ \\
\hline 30 & 210.5 & 343.7 & 370.3 & 554.9 & 857.7 & 912.4 & $84 \%$ & $8 \%$ & $2 \%$ & $6 \%$ & $0 \%$ \\
\hline 31 & 209.5 & 345.4 & 371.0 & 556.1 & 860.5 & 913.6 & $84 \%$ & $12 \%$ & $2 \%$ & $2 \%$ & $0 \%$ \\
\hline 39 & 211.2 & 344.3 & 370.8 & 554.0 & 863.8 & 908.4 & $96 \%$ & $0 \%$ & $0 \%$ & $4 \%$ & $0 \%$ \\
\hline 40 & 217.8 & 344.0 & 370.9 & 555.8 & 860.5 & 912.2 & $90 \%$ & $2 \%$ & $2 \%$ & $0 \%$ & $6 \%$ \\
\hline 42 & 211.8 & 343.0 & 371.5 & 554.7 & 862.0 & 912.6 & $88 \%$ & $6 \%$ & $4 \%$ & $2 \%$ & $0 \%$ \\
\hline 49 & 206.3 & 342.9 & 373.0 & 555.5 & 862.0 & 912.1 & $86 \%$ & $12 \%$ & $0 \%$ & $2 \%$ & $0 \%$ \\
\hline 53 & 212.9 & 343.1 & 370.9 & 556.5 & 856.3 & 911.5 & $72 \%$ & $0 \%$ & $28 \%$ & $0 \%$ & $0 \%$ \\
\hline 55 & 213.4 & 343.3 & 370.3 & 554.8 & 857.7 & 911.0 & $84 \%$ & $0 \%$ & $12 \%$ & $4 \%$ & $0 \%$ \\
\hline 57 & 211.5 & 344.5 & 370.6 & 555.5 & 860.2 & 914.2 & $74 \%$ & $10 \%$ & $16 \%$ & $0 \%$ & $0 \%$ \\
\hline 58 & 214.1 & 342.8 & 370.2 & 554.9 & 860.5 & 912.8 & $96 \%$ & $0 \%$ & $2 \%$ & $2 \%$ & $0 \%$ \\
\hline 59 & 210.8 & 343.7 & 370.2 & 555.0 & 859.1 & 912.6 & $84 \%$ & $8 \%$ & $4 \%$ & $4 \%$ & $0 \%$ \\
\hline 64 & 209.9 & 345.9 & 371.1 & 555.0 & 859.3 & 913.3 & $76 \%$ & $18 \%$ & $0 \%$ & $6 \%$ & $0 \%$ \\
\hline 65 & 212.3 & 343.4 & 370.4 & 555.2 & 860.3 & 914.1 & $88 \%$ & $8 \%$ & $0 \%$ & $4 \%$ & $0 \%$ \\
\hline 75 & 216.3 & 348.0 & 372.8 & 554.9 & 863.5 & 909.9 & $74 \%$ & $18 \%$ & $0 \%$ & $4 \%$ & $4 \%$ \\
\hline 77 & 213.2 & 344.2 & 371.5 & 555.7 & 861.0 & 914.4 & $84 \%$ & $10 \%$ & $4 \%$ & $2 \%$ & $0 \%$ \\
\hline 80 & 214.5 & 347.5 & 372.0 & 554.7 & 858.5 & 911.6 & $58 \%$ & $20 \%$ & $16 \%$ & $6 \%$ & $0 \%$ \\
\hline 98 & 213.8 & 344.6 & 371.9 & 555.9 & 861.3 & 915.3 & $74 \%$ & $12 \%$ & $14 \%$ & $0 \%$ & $0 \%$ \\
\hline 99 & 212.7 & 347.4 & 372.4 & 556.1 & 862.4 & 915.0 & $74 \%$ & $22 \%$ & $0 \%$ & $4 \%$ & $0 \%$ \\
\hline 112 & 217.3 & 345.6 & 373.1 & 556.7 & 862.8 & 915.2 & $80 \%$ & $16 \%$ & $0 \%$ & $0 \%$ & $4 \%$ \\
\hline 113 & 214.7 & 346.2 & 372.9 & 556.2 & 863.7 & 916.3 & $76 \%$ & $18 \%$ & $6 \%$ & $0 \%$ & $0 \%$ \\
\hline 116 & 211.3 & 354.7 & 372.8 & 557.3 & 858.6 & 913.2 & $26 \%$ & $50 \%$ & $16 \%$ & $8 \%$ & $0 \%$ \\
\hline 120 & 215.2 & 345.4 & 373.1 & 556.2 & 865.3 & 916.5 & $84 \%$ & $16 \%$ & $0 \%$ & $0 \%$ & $0 \%$ \\
\hline 122 & 213.8 & 348.2 & 373.6 & 556.9 & 863.6 & 916.8 & $64 \%$ & $30 \%$ & $6 \%$ & $0 \%$ & $0 \%$ \\
\hline 123 & 214.0 & 345.6 & 373.0 & 556.6 & 865.3 & 916.9 & $76 \%$ & $24 \%$ & $0 \%$ & $0 \%$ & $0 \%$ \\
\hline 125 & 214.2 & 34.6 & 372.6 & 556.5 & 864.8 & 916.8 & $100 \%$ & $0 \%$ & $0 \%$ & $0 \%$ & $0 \%$ \\
\hline 128 & 215.9 & 346.3 & 373.0 & 555.6 & 861.4 & 914.2 & $64 \%$ & $12 \%$ & $24 \%$ & $0 \%$ & $0 \%$ \\
\hline 131 & 213.8 & 346.4 & 373.0 & 556.9 & 864.9 & 917.2 & $76 \%$ & $24 \%$ & $0 \%$ & $0 \%$ & $0 \%$ \\
\hline 135 & 217.1 & 345.7 & 372.6 & 555.6 & 861.1 & 915.2 & $62 \%$ & $14 \%$ & $24 \%$ & $0 \%$ & $0 \%$ \\
\hline 136 & 213.6 & 346.2 & 372.3 & 556.5 & 865.2 & 917.3 & $76 \%$ & $24 \%$ & $0 \%$ & $0 \%$ & $0 \%$ \\
\hline 140 & 213.9 & 346.7 & 373.1 & 556.7 & 862.6 & 916.2 & $72 \%$ & $24 \%$ & $2 \%$ & $2 \%$ & $0 \%$ \\
\hline 144 & 224.0 & 347.1 & 373.5 & 556.4 & 863.2 & 916.0 & $74 \%$ & $18 \%$ & $0 \%$ & $0 \%$ & $8 \%$ \\
\hline 145 & 217.1 & 347.2 & 373.0 & 554.9 & 860.6 & 913.1 & $72 \%$ & $18 \%$ & $2 \%$ & $4 \%$ & $4 \%$ \\
\hline 150 & 216.1 & 345.5 & 372.7 & 555.9 & 865.0 & 916.7 & $84 \%$ & $16 \%$ & $0 \%$ & $0 \%$ & $0 \%$ \\
\hline 159 & 216.3 & 345.7 & 372.9 & 556.2 & 863.0 & 916.4 & $76 \%$ & $18 \%$ & $4 \%$ & $2 \%$ & $0 \%$ \\
\hline 164 & 213.9 & 346.9 & 373.0 & 556.8 & 864.8 & 917.7 & $74 \%$ & $26 \%$ & $0 \%$ & $0 \%$ & $0 \%$ \\
\hline 165 & 216.9 & 346.0 & 373.1 & 555.8 & 862.5 & 914.9 & $80 \%$ & $16 \%$ & $0 \%$ & $0 \%$ & $4 \%$ \\
\hline 169 & 214.3 & 346.9 & 372.9 & 556.5 & 864.6 & 917.6 & $74 \%$ & $26 \%$ & $0 \%$ & $0 \%$ & $0 \%$ \\
\hline 177 & 218.9 & 354.3 & 377.6 & 556.8 & 858.0 & 912.5 & $16 \%$ & $40 \%$ & $36 \%$ & $0 \%$ & $8 \%$ \\
\hline 180 & 217.4 & 345.6 & 373.1 & 555.2 & 860.4 & 914.0 & $62 \%$ & $10 \%$ & $28 \%$ & $0 \%$ & $0 \%$ \\
\hline 181 & 217.2 & 346.7 & 372.9 & 555.3 & 862.2 & 914.4 & $72 \%$ & $20 \%$ & $2 \%$ & $4 \%$ & $2 \%$ \\
\hline 182 & 217.4 & 343.7 & 373.1 & 556.7 & 864.4 & 916.4 & $86 \%$ & $12 \%$ & $2 \%$ & $0 \%$ & $0 \%$ \\
\hline 183 & 212.8 & 349.0 & 373.3 & 557.6 & 861.1 & 918.6 & $58 \%$ & $32 \%$ & $10 \%$ & $0 \%$ & $0 \%$ \\
\hline 184 & 214.8 & 347.0 & 372.7 & 556.9 & 865.0 & 917.8 & $75 \%$ & $25 \%$ & $0 \%$ & $0 \%$ & $0 \%$ \\
\hline 202 & 212.1 & 348.8 & 373.5 & 557.4 & 864.8 & 918.5 & $64 \%$ & $36 \%$ & $0 \%$ & $0 \%$ & $0 \%$ \\
\hline 203 & 213.4 & 346.6 & 372.9 & 556.7 & 864.3 & 917.6 & $74 \%$ & $26 \%$ & $0 \%$ & $0 \%$ & $0 \%$ \\
\hline 209 & 215.0 & 346.0 & 373.0 & 556.1 & 864.4 & 916.3 & $76 \%$ & $18 \%$ & $6 \%$ & $0 \%$ & $0 \%$ \\
\hline 211 & 214.8 & 345.9 & 372.4 & 556.4 & 864.5 & 916.9 & $84 \%$ & $16 \%$ & $0 \%$ & $0 \%$ & $0 \%$ \\
\hline 215 & 215.5 & 344.7 & 373.0 & 556.3 & 864.6 & 916.8 & $84 \%$ & $16 \%$ & $0 \%$ & $0 \%$ & $0 \%$ \\
\hline 221 & 215.6 & 345.2 & 372.5 & 556.4 & 866.9 & 916.9 & $84 \%$ & $16 \%$ & $0 \%$ & $0 \%$ & $0 \%$ \\
\hline 225 & 211.1 & 349.1 & 373.4 & 557.3 & 864.9 & 918.8 & $64 \%$ & $36 \%$ & $0 \%$ & $0 \%$ & $0 \%$ \\
\hline 232 & 217.8 & 344.8 & 372.4 & 554.5 & 860.0 & 912.8 & $72 \%$ & $4 \%$ & $22 \%$ & $0 \%$ & $2 \%$ \\
\hline 233 & 213.2 & 345.6 & 372.7 & 555.9 & 863.5 & 915.8 & $74 \%$ & $24 \%$ & $0 \%$ & $2 \%$ & $0 \%$ \\
\hline 234 & 213.3 & 346.4 & 372.6 & 556.4 & 864.8 & 917.0 & $76 \%$ & $24 \%$ & $0 \%$ & $0 \%$ & $0 \%$ \\
\hline 238 & 214.5 & $3,44,4$ & 372.3 & 555.9 & 863.4 & 916.1 & $86 \%$ & $10 \%$ & $4 \%$ & $0 \%$ & $0 \%$ \\
\hline 244 & 213.7 & 346.9 & 372.8 & 556.5 & 865.3 & 917.3 & $75 \%$ & $25 \%$ & $0 \%$ & $0 \%$ & $0 \%$ \\
\hline 246 & 213.8 & 344.7 & 372.3 & 555.5 & 862.8 & 916.1 & $84 \%$ & $14 \%$ & $2 \%$ & $0 \%$ & $0 \%$ \\
\hline 249 & 214.6 & 345.8 & 372.1 & 556.5 & 864.6 & 916.7 & $84 \%$ & $16 \%$ & $0 \%$ & $0 \%$ & $0 \%$ \\
\hline 259 & 216.6 & 344.9 & 372.8 & 555.4 & 860.1 & 913.5 & $72 \%$ & $8 \%$ & $18 \%$ & $2 \%$ & $0 \%$ \\
\hline 264 & 215.2 & 343.9 & 371.8 & 555.1 & 862.1 & 915.0 & $86 \%$ & $10 \%$ & $2 \%$ & $2 \%$ & $0 \%$ \\
\hline 266 & 214.6 & 346.0 & 373.9 & 556.7 & 865.6 & 917.0 & $76 \%$ & $24 \%$ & $0 \%$ & $0 \%$ & $0 \%$ \\
\hline 269 & 212.9 & 346.6 & 372.2 & 556.1 & 863.6 & 916.7 & $72 \%$ & $26 \%$ & $0 \%$ & $2 \%$ & $0 \%$ \\
\hline 270 & 213.9 & 345.0 & 371.6 & 555.6 & 864.9 & 916.8 & $84 \%$ & $16 \%$ & $0 \%$ & $0 \%$ & $0 \%$ \\
\hline
\end{tabular}

Sample P4959 - Praia do Navio beach placer

$\begin{array}{ccccccccc}3 & 214.1 & 344.5 & 371.7 & 555.6 & 864.9 & 916.2 & 84 \% & 16 \% \\ 4 & 215.2 & 346.6 & 372.3 & 555.5 & 861.8 & 915.1 & 72 \% & 22 \% \\ 12 & 214.2 & 344.6 & 371.6 & 555.5 & 863.9 & 919.2 & 84 \% & 16 \% \\ 13 & 206.3 & 346.8 & 372.4 & 556.2 & 863.5 & 916.8 & 72 \% & 28 \% \\ 17 & 214.0 & 344.5 & 371.6 & 555.6 & 839.5 & 916.3 & 10 \% & 0 \% \\ 24 & 216.3 & 345.3 & 372.9 & 554.8 & 861.6 & 913.8 & 74 \% & 12 \% \\ 28 & 215.4 & 343.7 & 371.5 & 555.0 & 850.5 & 915.3 & 48 \% & 0 \% \\ 31 & 219.2 & 348.3 & 374.8 & 554.1 & 844.4 & 910.5 & 0 \% & 0 \% \\ 32 & 218.1 & 344.0 & 371.4 & 554.8 & 861.3 & 915.0 & 86 \% & 6 \% \\ 33 & 213.2 & 346.7 & 371.7 & 554.9 & 863.6 & 913.8 & 74 \% & 22 \% \\ 36 & 211.9 & 346.0 & 372.6 & 556.0 & 863.0 & 916.6 & 74 \% & 24 \% \\ 44 & 214.2 & 342.4 & 371.5 & 554.6 & 862.7 & 915.1 & 98 \% & 2 \% \\ 46 & 216.0 & 344.6 & 371.7 & 554.6 & 861.7 & 914.1 & 84 \% & 12 \% \\ 50 & 213.2 & 346.3 & 372.2 & 555.9 & 863.3 & 916.6 & 74 \% & 24 \% \\ 51 & 216.0 & 345.5 & 372.4 & 554.6 & 860.3 & 913.7 & 72 \% & 14 \% \\ 55 & 213.4 & 346.8 & 372.9 & 555.7 & 862.2 & 916.1 & 72 \% & 24 \% \\ 57 & 211.6 & 346.4 & 372.3 & 556.2 & 861.8 & 917.3 & 74 \% & 22 \% \\ 58 & 212.2 & 347.2 & 372.6 & 556.5 & 864.2 & 917.6 & 74 \% & 26 \% \\ 59 & 216.0 & 346.3 & 372.9 & 555.1 & 863.3 & 913.4 & 76 \% & 16 \% \\ 60 & 214.6 & 346.7 & 371.6 & 556.1 & 863.6 & 916.9 & 74 \% & 24 \% \\ 63 & 212.0 & 346.5 & 371.1 & 556.2 & 863.9 & 917.1 & 76 \% & 24 \% \\ 70 & 213.4 & 346.6 & 372.7 & 556.3 & 864.3 & 916.6 & 72 \% & 26 \% \\ 71 & 212.6 & 347.4 & 372.9 & 556.8 & 864.9 & 917.9 & 74 \% & 26 \% \\ 76 & 214.6 & 345.5 & 372.7 & 554.6 & 862.0 & 914.6 & 76 \% & 18 \% \\ 78 & 211.9 & 346.4 & 372.4 & 556.4 & 864.6 & 917.4 & 76 \% & 24 \% \\ 86 & 216.2 & 345.2 & 372.3 & 554.8 & 856.0 & 914.0 & 58 \% & 4 \% \\ 87 & 212.9 & 347.0 & 372.5 & 556.0 & 864.8 & 917.5 & 74 \% & 26 \% \\ 92 & 213.3 & 346.3 & 372.4 & 556.3 & 864.7 & 917.2 & 76 \% & 24 \% \\ 93 & 220.0 & 345.6 & 372.3 & 554.9 & 864.3 & 914.1 & 82 \% & 12 \% \\ 94 & 213.6 & 345.9 & 372.5 & 556.1 & 863.8 & 917.0 & 74 \% & 22 \% \\ & & & & & & & & \end{array}$

$\begin{array}{cccc}16 \% & 0 \% & 0 \% & 0 \% \\ 22 \% & 2 \% & 4 \% & 0 \% \\ 16 \% & 0 \% & 0 \% & 0 \% \\ 28 \% & 0 \% & 0 \% & 0 \% \\ 0 \% & 90 \% & 0 \% & 0 \% \\ 12 \% & 12 \% & 2 \% & 0 \% \\ 0 \% & 52 \% & 0 \% & 0 \% \\ 0 \% & 100 \% & 0 \% & 0 \% \\ 6 \% & 4 \% & 2 \% & 2 \% \\ 22 \% & 0 \% & 4 \% & 0 \% \\ 24 \% & 0 \% & 2 \% & 0 \% \\ 2 \% & 0 \% & 0 \% & 0 \% \\ 12 \% & 0 \% & 4 \% & 0 \% \\ 24 \% & 0 \% & 2 \% & 0 \% \\ 14 \% & 10 \% & 4 \% & 0 \% \\ 24 \% & 0 \% & 4 \% & 0 \% \\ 22 \% & 2 \% & 2 \% & 0 \% \\ 26 \% & 0 \% & 0 \% & 0 \% \\ 16 \% & 4 \% & 4 \% & 0 \% \\ 24 \% & 0 \% & 2 \% & 0 \% \\ 24 \% & 0 \% & 0 \% & 0 \% \\ 26 \% & 0 \% & 2 \% & 0 \% \\ 26 \% & 0 \% & 0 \% & 0 \% \\ 18 \% & 2 \% & 4 \% & 0 \% \\ 24 \% & 0 \% & 0 \% & 0 \% \\ 4 \% & 38 \% & 0 \% & 0 \% \\ 26 \% & 0 \% & 0 \% & 0 \% \\ 24 \% & 0 \% & 0 \% & 0 \% \\ 12 \% & 0 \% & 0 \% & 6 \% \\ 22 \% & 4 \% & 0 \% & 0 \% \\ & & & \end{array}$




\begin{tabular}{|c|c|c|c|c|c|c|c|c|c|c|c|}
\hline & & & & \multicolumn{8}{|c|}{ Sedimentology } \\
\hline 96 & 212.0 & 346.3 & 371.4 & 556.3 & 863.2 & 917.0 & $84 \%$ & $16 \%$ & $0 \%$ & $0 \%$ & $0 \%$ \\
\hline 97 & 214.4 & 346.6 & 372.2 & 556.3 & 864.8 & 917.4 & $76 \%$ & $24 \%$ & $0 \%$ & $0 \%$ & $0 \%$ \\
\hline 100 & 214.7 & 344.4 & 371.5 & 555.6 & 863.1 & 915.8 & $86 \%$ & $10 \%$ & $4 \%$ & $0 \%$ & $0 \%$ \\
\hline 101 & 214.1 & 346.0 & 372.3 & 555.9 & 864.1 & 916.7 & $84 \%$ & $16 \%$ & $0 \%$ & $0 \%$ & $0 \%$ \\
\hline 102 & 213.5 & 345.7 & 372.5 & 556.0 & 864.3 & 916.9 & $74 \%$ & $22 \%$ & $4 \%$ & $0 \%$ & $0 \%$ \\
\hline 105 & 213.8 & 345.8 & 372.7 & 555.6 & 862.7 & 916.0 & $74 \%$ & $22 \%$ & $2 \%$ & $2 \%$ & $0 \%$ \\
\hline 107 & 213.7 & 345.6 & 372.4 & 555.6 & 862.5 & 916.5 & $76 \%$ & $18 \%$ & $6 \%$ & $0 \%$ & $0 \%$ \\
\hline 109 & 213.2 & 344.8 & 372.9 & 555.6 & 863.9 & 916.3 & $84 \%$ & $16 \%$ & $0 \%$ & $0 \%$ & $0 \%$ \\
\hline 110 & 215.4 & 343.5 & 371.7 & 554.8 & 864.3 & 915.4 & $86 \%$ & $12 \%$ & $0 \%$ & $2 \%$ & $0 \%$ \\
\hline 112 & 214.5 & 345.7 & 373.5 & 554.8 & 860.5 & 913.6 & $72 \%$ & $16 \%$ & $8 \%$ & $4 \%$ & $0 \%$ \\
\hline 113 & 215.5 & 346.5 & 372.5 & 555.8 & 861.0 & 915.0 & $62 \%$ & $16 \%$ & $22 \%$ & $0 \%$ & $0 \%$ \\
\hline 114 & 215.9 & 344.4 & 371.5 & 554.6 & 862.0 & 914.4 & $86 \%$ & $10 \%$ & $0 \%$ & $4 \%$ & $0 \%$ \\
\hline 116 & 210.1 & 349.3 & 373.4 & 557.1 & 864.4 & 918.7 & $64 \%$ & $36 \%$ & $0 \%$ & $0 \%$ & $0 \%$ \\
\hline 117 & 211.8 & 347.4 & 373.4 & 556.6 & 864.2 & 917.0 & $75 \%$ & $25 \%$ & $0 \%$ & $0 \%$ & $0 \%$ \\
\hline 118 & 220.1 & 347.2 & 371.4 & 554.5 & 863.1 & 913.7 & $78 \%$ & $14 \%$ & $0 \%$ & $0 \%$ & $8 \%$ \\
\hline 119 & 213.2 & 346.1 & 372.4 & 556.1 & 875.3 & 917.1 & $72 \%$ & $28 \%$ & $0 \%$ & $0 \%$ & $0 \%$ \\
\hline 120 & 214.7 & 344.1 & 371.9 & 555.0 & 864.3 & 915.1 & $86 \%$ & $12 \%$ & $0 \%$ & $2 \%$ & $0 \%$ \\
\hline 123 & 216.2 & 349.5 & 375.9 & 554.0 & 859.5 & 912.0 & $46 \%$ & $30 \%$ & $16 \%$ & $8 \%$ & $0 \%$ \\
\hline 125 & 213.2 & 345.7 & 372.3 & 555.9 & 863.6 & 916.7 & $84 \%$ & $16 \%$ & $0 \%$ & $0 \%$ & $0 \%$ \\
\hline 126 & 213.1 & 346.1 & 371.9 & 556.0 & 864.6 & 916.9 & $76 \%$ & $24 \%$ & $0 \%$ & $0 \%$ & $0 \%$ \\
\hline 130 & 211.6 & 346.8 & 372.9 & 556.2 & 864.7 & 917.4 & $75 \%$ & $25 \%$ & $0 \%$ & $0 \%$ & $0 \%$ \\
\hline 132 & 212.0 & 346.6 & 372.5 & 556.3 & 864.3 & 917.2 & $72 \%$ & $26 \%$ & $0 \%$ & $2 \%$ & $0 \%$ \\
\hline 133 & 213.5 & 345.6 & 371.8 & 556.1 & 863.8 & 916.8 & $84 \%$ & $16 \%$ & $0 \%$ & $0 \%$ & $0 \%$ \\
\hline 134 & 213.0 & 346.7 & 372.1 & 556.3 & 864.4 & 917.2 & $72 \%$ & $26 \%$ & $0 \%$ & $2 \%$ & $0 \%$ \\
\hline 139 & 214.4 & 346.1 & 372.5 & 555.3 & 862.8 & 914.8 & $74 \%$ & $22 \%$ & $0 \%$ & $4 \%$ & $0 \%$ \\
\hline 142 & 216.3 & 346.7 & 373.0 & 555.0 & 860.3 & 913.2 & $62 \%$ & $16 \%$ & $18 \%$ & $4 \%$ & $0 \%$ \\
\hline 143 & 213.2 & 345.5 & 372.0 & 555.8 & 864.8 & 917.0 & $76 \%$ & $24 \%$ & $0 \%$ & $0 \%$ & $0 \%$ \\
\hline 148 & 215.0 & 344.3 & 371.8 & 555.4 & 862.4 & 915.4 & $86 \%$ & $10 \%$ & $2 \%$ & $2 \%$ & $0 \%$ \\
\hline 149 & 213.6 & 345.0 & 372.1 & 555.7 & 861.1 & 916.7 & $76 \%$ & $18 \%$ & $4 \%$ & $2 \%$ & $0 \%$ \\
\hline 152 & 212.9 & 346.3 & 372.8 & 556.2 & 864.9 & 917.0 & $76 \%$ & $24 \%$ & $0 \%$ & $0 \%$ & $0 \%$ \\
\hline 155 & 213.9 & 345.2 & 371.5 & 555.7 & 863.3 & 916.2 & $84 \%$ & $14 \%$ & $2 \%$ & $0 \%$ & $0 \%$ \\
\hline 158 & 221.8 & 350.6 & 374.9 & 553.4 & 852.1 & 906.9 & $14 \%$ & $8 \%$ & $70 \%$ & $0 \%$ & $8 \%$ \\
\hline 163 & 215.1 & 342.7 & 371.6 & 554.7 & 863.2 & 915.1 & $88 \%$ & $6 \%$ & $6 \%$ & $0 \%$ & $0 \%$ \\
\hline 164 & 212.3 & 347.1 & 372.8 & 556.5 & 864.4 & 917.2 & $75 \%$ & $25 \%$ & $0 \%$ & $0 \%$ & $0 \%$ \\
\hline 166 & 213.5 & 347.1 & 372.8 & 556.6 & 865.7 & 917.5 & $74 \%$ & $26 \%$ & $0 \%$ & $0 \%$ & $0 \%$ \\
\hline 168 & 213.7 & 353.4 & 375.3 & 555.4 & 856.6 & 912.4 & $18 \%$ & $38 \%$ & $38 \%$ & $6 \%$ & $0 \%$ \\
\hline 169 & 215.1 & 344.7 & 373.0 & 554.8 & 865.4 & 913.9 & $84 \%$ & $14 \%$ & $0 \%$ & $2 \%$ & $0 \%$ \\
\hline 172 & 216.2 & 347.0 & 373.4 & 555.0 & 861.2 & 912.7 & $72 \%$ & $20 \%$ & $0 \%$ & $6 \%$ & $2 \%$ \\
\hline 176 & 212.2 & 346.6 & 372.5 & 556.2 & 864.2 & 917.0 & $72 \%$ & $26 \%$ & $0 \%$ & $2 \%$ & $0 \%$ \\
\hline 177 & 214.3 & 346.3 & 372.6 & 555.7 & 862.1 & 915.2 & $74 \%$ & $18 \%$ & $6 \%$ & $2 \%$ & $0 \%$ \\
\hline 181 & 215.8 & 346.9 & 370.7 & 556.0 & 864.0 & 916.4 & $74 \%$ & $22 \%$ & $2 \%$ & $2 \%$ & $0 \%$ \\
\hline 182 & 213.5 & 344.9 & 372.7 & 555.1 & 865.4 & 915.6 & $84 \%$ & $16 \%$ & $0 \%$ & $0 \%$ & $0 \%$ \\
\hline 185 & 212.8 & 348.5 & 372.3 & 557.0 & 864.2 & 918.0 & $62 \%$ & $36 \%$ & $0 \%$ & $2 \%$ & $0 \%$ \\
\hline 186 & 214.1 & 344.3 & 372.0 & 555.3 & 862.9 & 915.8 & $86 \%$ & $12 \%$ & $0 \%$ & $2 \%$ & $0 \%$ \\
\hline 189 & 215.3 & 346.2 & 371.9 & 555.0 & 861.7 & 914.5 & $76 \%$ & $18 \%$ & $2 \%$ & $4 \%$ & $0 \%$ \\
\hline 190 & 215.2 & 344.6 & 372.4 & 555.4 & 863.4 & 916.4 & $84 \%$ & $14 \%$ & $0 \%$ & $2 \%$ & $0 \%$ \\
\hline 191 & 216.0 & 348.5 & 371.2 & 553.8 & 868.8 & 912.5 & $74 \%$ & $24 \%$ & $0 \%$ & $2 \%$ & $0 \%$ \\
\hline 193 & 215.6 & 346.6 & 372.7 & 554.8 & 861.1 & 913.6 & $72 \%$ & $20 \%$ & $2 \%$ & $6 \%$ & $0 \%$ \\
\hline 197 & 212.7 & 345.0 & 372.0 & 555.4 & 867.6 & 916.1 & $84 \%$ & $16 \%$ & $0 \%$ & $0 \%$ & $0 \%$ \\
\hline 200 & 216.0 & 345.9 & 372.6 & 555.8 & 865.4 & 915.7 & $80 \%$ & $18 \%$ & $0 \%$ & $0 \%$ & $2 \%$ \\
\hline 201 & 216.3 & 345.9 & 372.4 & 555.0 & 860.5 & 913.9 & $74 \%$ & $14 \%$ & $8 \%$ & $4 \%$ & $0 \%$ \\
\hline 202 & 213.3 & 346.2 & 372.3 & 556.0 & 863.6 & 916.7 & $84 \%$ & $16 \%$ & $0 \%$ & $0 \%$ & $0 \%$ \\
\hline 205 & 218.3 & 344.6 & 371.2 & 553.0 & 864.3 & 914.2 & $86 \%$ & $10 \%$ & $0 \%$ & $4 \%$ & $0 \%$ \\
\hline 206 & 213.4 & 347.2 & 372.5 & 556.8 & 864.7 & 917.2 & $75 \%$ & $25 \%$ & $0 \%$ & $0 \%$ & $0 \%$ \\
\hline 207 & 211.0 & 347.7 & 373.0 & 556.8 & 864.9 & 917.6 & $72 \%$ & $28 \%$ & $0 \%$ & $0 \%$ & $0 \%$ \\
\hline 209 & 221.3 & 349.1 & 373.3 & 555.1 & 855.6 & 912.8 & $46 \%$ & $14 \%$ & $32 \%$ & $0 \%$ & $8 \%$ \\
\hline
\end{tabular}

Page 80 of 81 


\section{Page 81 of 81}

Sedimentology

$\begin{array}{llllllll}\% & \% & \% & \% & \% & \% & \text { grain } & \begin{array}{c}\text { grain } \\ \text { density }\end{array} \text { standard }\end{array}$

6 SOUTHERN ANGOLAN COAST

8 (inner berm) Inamangando

9 (outer berm) Inamangando

1aberm)

Inamangando
Bentiaba

zircon monazite

garnet magnetite ilmenite intrabasinal density)

$\left(\mathrm{g} / \mathrm{cm}^{3}\right) \quad$ deviation Major potential reason for inaccurate density measures or SRD values

shore)

13MOÇAMEDES DESERT

Vanesa

$\begin{array}{llll}\mathrm{S} 4945 & 4.0 & 3.1 & 0.04\end{array}$

$0.06 \quad$ n.f. 0.02

$\begin{array}{llllll}S 4943 & 12.4 & 3.2 & 0.29 & \text { n.f. } & 0.03\end{array}$

$\begin{array}{llll}54948 & 6.9 & 4.2 & 0.06\end{array}$

$\begin{array}{ll}\text { n.f. } & 0.03 \\ \text { n.f. } & 0.02\end{array}$

0.2
1.6

8.5

$\begin{array}{llll}\mathrm{P} 4948 & 96.9 & 7.7 & 2.8\end{array}$

$0.6 \quad 0.40$

76.4

12.3

\section{0}

2.68

2.67 0.01 SRD ignores mineral weathering and inclusions, underestimating density

2.67 0.02 SRD ignores mineral weathering and intrabasinal grains

$2.77 \quad 0.03$ Inaccurate quartering due to formation of magnetite clusters

2.64 $0.01 \mathrm{SRD}$ ignores common intrabasinal grains with intragranular pores

$\begin{array}{llll}S 4957 & 3.9 & 2.6 & 0.05\end{array}$

n.f. $\quad 1.1$

$\begin{array}{lllll}\text { Vanesinha } & \mathrm{S} 4958 & 15.1 & 11.9 & 0.02\end{array}$

n.f. $\quad 8.2$

0.5

$$
4.81
$$

4.61

0.04 Inaccurate estimate of the average density of Fe-Ti-Cr oxides

$\begin{array}{lllll}\text { Praia do Navio } & S 4959 & 11.8 & 8.0 & 0.26\end{array}$

$\begin{array}{lllll}\text { Cova dos Medos } & S 4961 & 30.2 & 21.0 & 0.50\end{array}$

n.f. $\quad 4.2$

$\begin{array}{ll}\text { n.f. } & 4.2 \\ \text { n.f. } & 8.2\end{array}$

(eolian dune)

Praia do Navio

$\begin{array}{llll}\mathrm{S} 4960 & 51.8 & 27.8 & 1.8\end{array}$

n.f. $\quad 17.2$

1.7

1.7
2.2
3.7

3.7

19.7

$\begin{array}{ll}2.0 & 2.69 \\ 3.8 & 2.85\end{array}$

2.67 $0.01 \mathrm{SRD}$ ignores weathering and presence of common intrabasinal grains

2.78 0.01 SRD ignores weathering and common intrabasinal grains

2.76 $0.00 \mathrm{SRD}$ ignores weathering and presence of intrabasinal grains

$1.1 \quad 2.80$

$\begin{array}{ll}1.4 & 2.98\end{array}$

LACER LAGS

(foreshore)

Vanesinha

Praia do Navio

$\begin{array}{llll}\text { P4958 } & 98.8 & 37.3 & 2.0\end{array}$

$0.3 \quad 31.6$

0.8

2.82

3.26 0.01 Inaccurate estimate of oxide density and common intrabasinal grains

$\begin{array}{llll}\mathrm{P} 4959 & 95.7 & 53.8 & 0.95\end{array}$

$0.3 \quad 47.8$

\section{4}

6.6

$1.4 \quad 4.57$

4.40

0.01 Inaccurate estimate of the average density of Fe-Ti-Cr oxides

$\begin{array}{llll}\mathrm{P} 4336 & 62.0 & 32.5 & 4.00\end{array}$

0

8.5

27.5

$\begin{array}{lll}4.2 & 0.5 & 4.33\end{array}$

4.17 0.05 Inaccurate estimate of the average density of Fe-Ti-Cr oxides

Shawnee

$\begin{array}{lll}P 4330 & 84.8 & 70.0\end{array}$

$\begin{array}{cc}8.5 & 27.5 \\ 49.2 & 13.3\end{array}$

2.0

0.0

3.67

3.23 0.06 Magnetite clusters and mixing with laminae of non-placer sand 3.75 0.02 Weathering, estimate of oxide density and few intrabasinal grains 


\section{Page 83 of 81}

\section{Sedimentology}



Fig. A1 Moçamedes

$90 \times 140 \mathrm{~mm}(300 \times 300 \mathrm{DPI})$ 